\title{
APLICAÇ̃̃o dE dIÓXIDO DE CARBONO VIA ÁGUA DE IRRIGAÇÃO EM MELOEIRO
}

\author{
JOSÉ MARIA PINTO
}

Engenheiro Agrícola

Orientador: Prof. Dr. TARLEI ARRIEL BOTREL Co-orientador: Dr. EDUARDO CARUSO MACHADO

Tese apresentada à Escola Superior de Agricultura "Luiz de Queiroz", Universidade de São Paulo, para obtenção do título de Doutor em Agronomia, Área de Concentração: Irrigação e Drenagem.

PIRACICABA

Estado de São Paulo - Brasil

Novembro - 1997 
Dados Internacionais de Catalogação na Publicação (CIP) DIVISĀO DE BIBLIOTECA E DOCUMENTAÇĀO - Campus "Luiz de Queiroz"/USP

Pinto, José Maria

Aplicação de dióxido de carbono via água de irrigação em meloeiro / José Maria Pinto. - - Piracicaba, 1997.

82 p. : il.

Tese (doutorado) - Escola Superior de Agricultura Luiz de Queiroz, 1998. Bibliografia.

1. Água de irrigação 2. Dioxido de carbono 3. Irrigação 4. Melão I. Título 


\section{APLICAÇÃO DE DIÓXIDO DE CARBONO VIA ÁGUA DE IRRIGAÇÃO EM MELOEIRO}

JOSÉ MARIA PINTO

Aprovada em 06/02/1998

Comissão julgadora:

Dr. Eduardo Caruso Machado

IAC

Dr. Flávio Bussmmeyer Arruda

IAC

Prof. Dr. Fernando Braz Tangerino Hernandez

FEIS/UNESP

Prof. Dr. João Carlos Curi Saad FCA/UNESP

Prof. Dr. Sérgio Nascimento Duarte ESALQ/USP

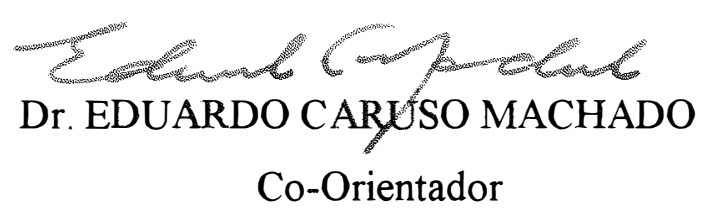


Durante décadas, lutei desesperadamente para trazer racionalidade às gerações que me sucederiam, acreditando na ciência e em suas conquistas. A caminhada do homem na Lua, as fotos dos planetas distantes, os computadores, a televisão direta dos satélites, as vacinas que eliminaram da face da Terra a variola e a poliomielite, os remédios desenhados em computadores que curam o câncer quando detectado a tempo, os transplantes de coração e rins, a biotecnologia gerando plantas mais resistentes e mais produtivas, que liquidaram com a profecia de Malthus, afastando o perigo da fome universal. E, apesar disso, o que colhemos? Uma geração de crédulos sem capacidade crítica.

Até mesmo pessoas que seguiram carreira técnico-cientifica não entendem a racionalidade da ciência. Consomem toneladas de pseudomedicamentos sem nenhum efeito positivo para o organismo. Engolem comprimidos de vitaminas que serão eliminados na urina. Consomem extratos de plantas com substâncias tóxicas e abandonam o tratamento médico. Gastam fortunas com diferentes marcas de xampu que contêm sempre o mesmo detergente mas anunciam "alimentos" para os cabelos, que estes recebem nutrientes diretamente do sangue que irriga suas raizes.

Mas nem tudo está perdido. Ainda há quem encontre motivação para se guiar pelo racionalismo e pela ciência - e para mudar. E há muito que fazer. É preciso combater o irracionalismo e as mistificações, onde quer que eles se manifestem: na televisão, nos locais de trabalho, nas faculdades. Podemos começar pela educação. Hoje, as pessoas passam um terço da vida nas salas de aula sem aprender e ninguém se importa. Criamos robôs que nos permitem ter uma produção cada vez maior de bens, mas ficamos prisioneiros de uma sociedade cada vez menos justa. Numa sociedade em que a ciência expandiu a longevidade do homem, não oferecemos à maioria da população segurança fisica nem acesso ao que a medicina modema pode oferecer - nem mesmo a garantia de teto e comida.

Enfim, criamos um campo propício para a proliferação dos enganadores. Está na hora de quebrar a insensibilidade dos govemos e das lideranças para tentar corrigir isso. Não será nos entregando à irracionalidade que sairemos desse buraco e construiremos um futuro melhor para os nossos netos. 
A meus queridos pais,

pela vida árdua e sacrificada para criar e educar os seus filhos, incentivando-me a prosseguir a jornada, fossem quais fossem os obstáculos.

Dedico esta conquista com o mais profundo amor, admiração e respeito.

A meus irmãos e sobrinhos

A Tânia Márcia, pelo carinho e compreensão, pelo sacrificio e paciência, e ao nosso filho, cuja chegada a este mundo está sendo aguardada com muita expectativa, OFEREÇO. 


\section{AGRADECIMENTOS}

A Deus, pela fé e perseverança, presentes em todos os momentos.

Ao Prof. Dr. Tarlei Arriel Botrel, pela orientação, amizade sincera, apoio, estímulo e pelos ensinamentos durante o curso e durante a realização deste trabalho.

Ao Dr. Eduardo Caruso Machado, pelo empenho, pelos ensinamentos e valiosa colaboração, pela amizade, espontaneidade de gênio, estímulo, oportunidade de convivência e exemplo de dedicação e profissionalismo.

Ao Prof. Dr. Marcos Vinícius Folegatti pelo incentivo, apoio, confiança e amizade.

Aos Professores: Dr. Fernando Braz Tangerino Hernandez, Dr. João Carlos Curi Saad, Dr. Sérgio Nascimento Duarte e ao Dr. Flávio Bussemmeier Amuda pelas valiosas sugestões apresentadas durante a defesa deste trabalho.

Ao Dr. Orivaldo Brunini pela galhardia em ceder o equipamento utilizado na coleta de dados de fotossíntese.

Aos Professores do Departamento de Engenharia Rural pelos ensinamentos e pela amizade.

Ao colegas de curso, pelo companheirismo, agradável convivência e sugestões.

Ao colega Camilo Lázaro Medina pela amizade, apoio e valiosa colaboração durante a realização do experimento.

Aos colegas Francisco Adriano Pereira e Luis Fernando Campeche pela colaboração na coleta e processamento dos dados climáticos.

À Prof ${ }^{\mathrm{a}}$. Fernanda Bacelar pela distinta amizade, incentivo e apoio em todos os momentos.

Ao José Figueiredo pela amizade sincera e colaboração durante a realização do trabalho. 
Aos funcionários do Departamento de Engenharia Rural: Hélio Toledo Gomes, Antônio Cesar Souza Rocha, Gilmar Batista Grigolon e ao ex-funcionário Renato Benedito Nicolau, pela colaboração.

Ao funcionário da Seção de Fisiologia do IAC de Campinas, Severino Silva Nogueira pela colaboração.

À Rachel Elizabet Domarco e Clarice Matraia da Seção de Entomologia do CENA pela realização das análises químicas dos frutos.

Aos funcionários da Seção de Empréstimo da Biblioteca Central - DIRB: Fátima, Silvana, Alvaro, Aírton e Ronaldo pela dedicação e celeridade no atendimento.

Às bibliotecárias Kátia M. de Andrade Ferraz e Eliana M. Garcia Sabino pelo eficiente dedicado atendimento.

À Seção de Horticultura da ESALQ pela colaboração na formação das mudas para os experimentos.

À Empresa Brasileira de Pesquisa Agropecuária - Embrapa e ao Centro de Pesquisa Agropecuária do Trópico Semi-Árido - CPATSA pela oportunidade oferecida de realizar este curso.

À Escola Superior de Agricultura "Luiz de Queiroz", através do Departamento de Engenharia Rural, pela acolhida e apoio.

À Capes e ao CNPq pela bolsa de estudo concedida.

À Fundação de Amparo à Pesquisa do Estado de São Paulo - FAPESP pelo suporte financeiro para a realização deste trabalho.

À White Martins e Liquid Carbonic pela concessão de materiais e equipamentos necessários à execução desta pesquisa.

A todos que, direta ou indiretamente, colaboraram para a realização deste trabalho. 


\section{SUMÁRIO}

Página

RESUMO

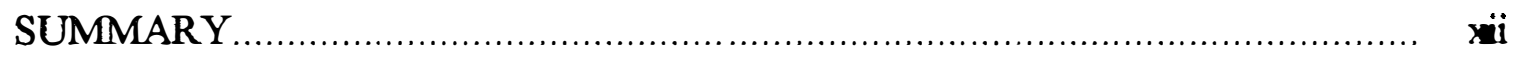

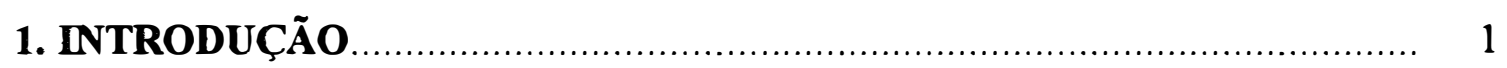

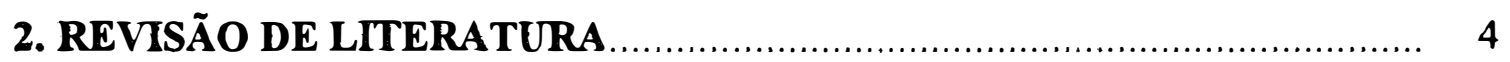

2.1 Efeito do dióxido de carbono sobre as plantas........................................... 6

2.2 Outras aplicações do dióxido de carbono na Agricultura ............................. 9

2.3 Aspectos gerais da cultura do melão .......................................................... 10

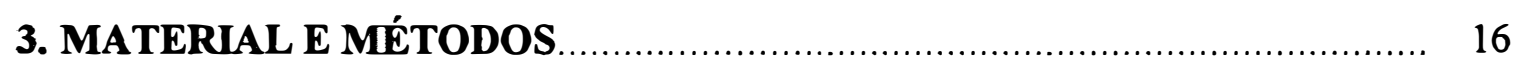

3.1 Curvas de respostas da taxa de assimilação de $\mathrm{CO}_{2}$ à concentração de dióxido de carbono e ao PAR .......................................................................... 16

3.2 Aplicação de dióxido de carbono via água de irrigação.............................. 20

3.2.1 Localização do experimento................................................................... 20

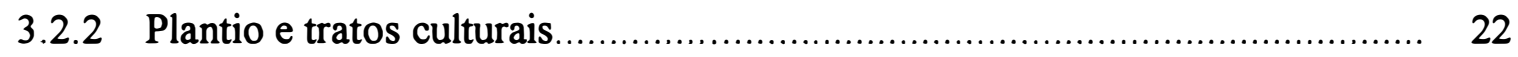

3.2.3 Irrigação e aplicação de dióxido de carbono............................................... 23

3.3 Tratamentos e análise estatística............................................................. 28

3.3.1 Aplicação de dióxido de carbono em condições de campo.......................... 28

3.3.2 Aplicação de dióxido de carbono em ambiente protegido............................ 30

3.4 Parâmetros avaliados nos experimentos de campo e de ambiente

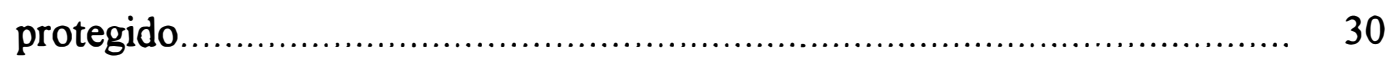

3.4.1 Produção de frutos........................................................................... 30

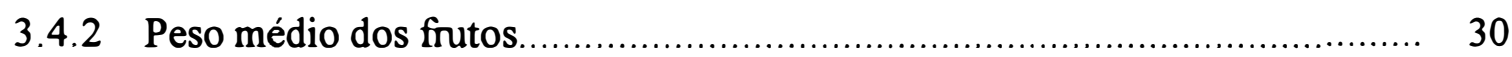

3.4.3 Teor de sólidos solúveis, acidez total e pH......................................... 30

3.4.4 Análise química de folhas................................................................... 31 
3.4.5 Taxa de assimilação de $\mathrm{CO}_{2}$ pelas plantas........................................... 31

3.4.6 Eficiência do uso de água...................................................................... 32

3.4.7 Índice de aproveitamento comercial da produção.................................. 32

4. RESULTADOS E DISCUSSÃO ....................................................... 33

4.1 Taxa de assimilação de $\mathrm{CO}_{2}$ em função da concentração de dióxido de

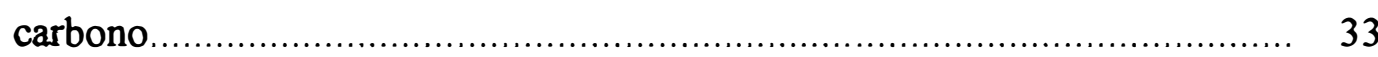

4.2 Taxa de assimilação de $\mathrm{CO}_{2}$ em função da radiação fotossinteticamente 35 ativa.

4.3 Aplicação de dióxido de carbono via água de irrigação em meloeiro em condições de campo ........................................................................... 36

4.3.1 Desenvolvimento da cultura ....................................................... 36

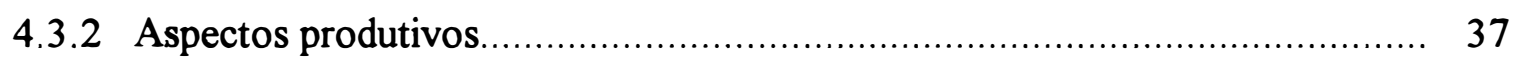

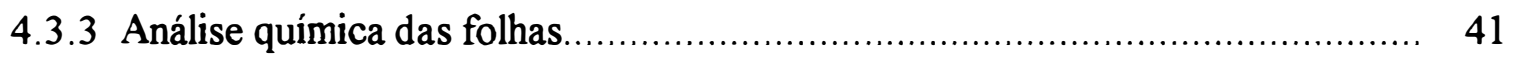

4.3.4 Eficiência no uso de água para as condições de campo................................ 45

4.4 Aplicação de dióxido de carbono via água de irrigação em meloeiro em condições de ambiente protegido.............................................................. 46

4.4.1 Desenvolvimento da cultura .......................................................... 46

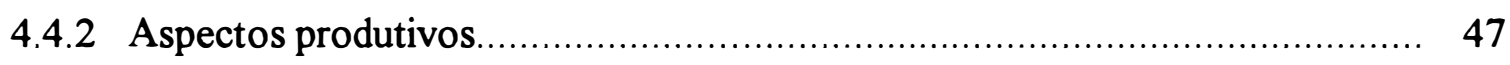

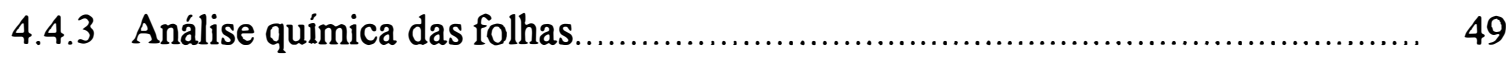

4.4.4 Eficiência no uso de água para as condições de ambiente protegido.............. 49

4.5 Considerações finais.......................................................................... 51

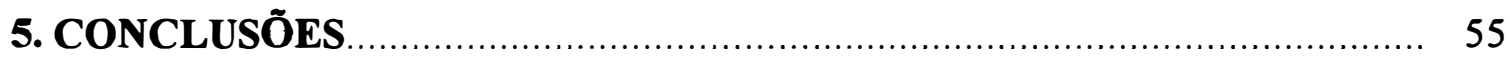

ANEXO

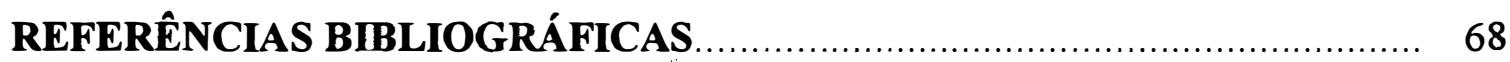




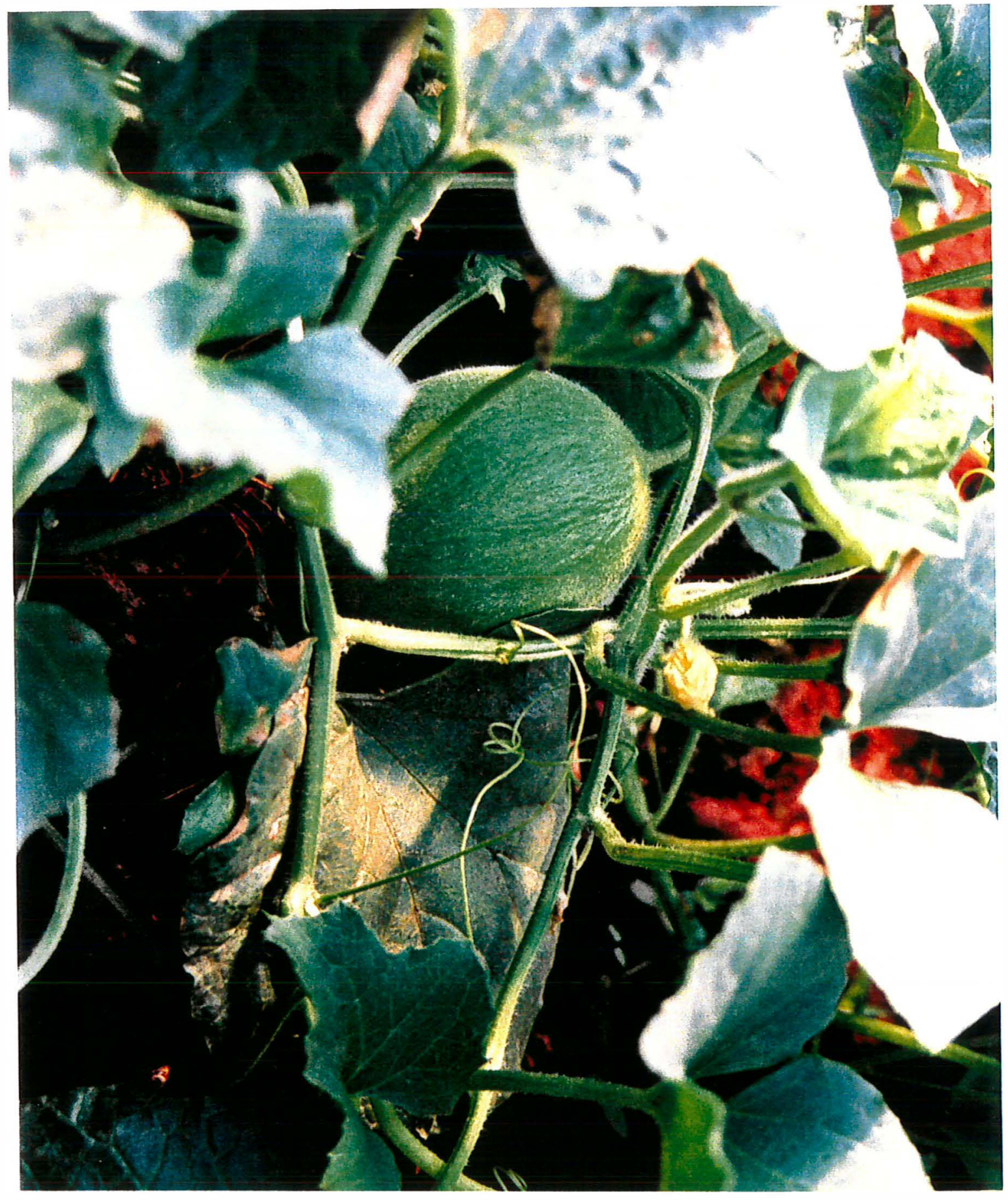

Sou a planta humilde dos quintais pequenos e das lavouras pobres.

Meu grão, perdido por acaso, nasce e cresce na terra descuidada. 


\title{
APLICAÇÃo DE DIÓXIDO DE CARBONO VIA ÁGUA DE IRRIGAÇÃo EM MELOEIRO
}

\author{
Autor: José Maria Pinto \\ Orientador: Prof. Dr. Tarlei Arriel Botrel \\ Co-orientador: Dr. Eduardo Caruso Machado
}

\section{RESUMO}

O ciclo do carbono na biosfera tem sido significativamente alterado pela atividade

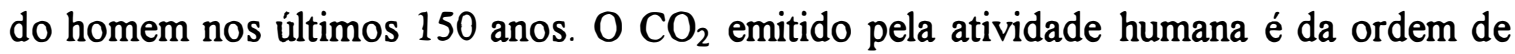
8,5 bilhões de toneladas anuais, como conseqüência a concentração de $\mathrm{CO}_{2}$ atmosférico está aumentando. Estudos relacionados aos efeitos do aumento artificial da concentração de $\mathrm{CO}_{2}$ sobre as plantas usados para obtenção de produtos em maior quantidade e melhor qualidade permite-nos conhecer a capacidade das plantas de adaptarem-se a esses ambientes.

O melão é uma das importantes culturas do país, ocupando lugar de destaque na olericultura brasileira, sendo produto de exportação. No entanto, fatores relacionados a aplicação de dióxido de carbono via água de irrigação necessita de estudos ecofisiológicos referentes às trocas de $\mathrm{CO}_{2}$ mais detalhados. Deve-se, também, determinar doses a serem usadas e períodos de aplicação mais adequados para os diferentes tipos de cultivos, para alcançar uma relação máxima beneficio custo.

Pretendeu-se com este estudo determinar o ponto de saturação lumínica e fotossintético para a cultura do melão; quantificar a taxa de assimilação de $\mathrm{CO}_{2}$ e a produtividade e avaliar as características químicas $(\mathrm{pH}$, acidez total e teor de sólidos solúveis, ${ }^{\circ}$ Brix) dos frutos de melão na colheita e durante o armazenamento. Para tanto, conduziu-se um estudo com a cultura do melão, realizado em três etapas. A primeira etapa, em condições de casa de vegetação, teve como objetivo determinar curvas de 
respostas da taxa de assimilação de $\mathrm{CO}_{2}$ em função do fluxo de fotons fotossinteticamente ativos e da concentração $\mathrm{CO}_{2}$. A segunda etapa, em condições de campo, e a terceira, em condições de ambiente protegido, com aplicação de $\mathrm{CO}_{2}$ via água de irrigação localizada, visaram determinar os efeitos sobre a produção da cultura do melão, qualidade dos frutos e taxa de assimilação de $\mathrm{CO}_{2}$.

As equações ajustadas, na primeira etapa, para taxa de assimilação de $\mathrm{CO}_{2}$ em função da concentração de $\mathrm{CO}_{2}$, para radiação fotossinteticamente ativa em torno de 850 , 550 e $300 \mu \mathrm{mol} . \mathrm{m}^{-2} . \mathrm{s}^{-1}$ foram, respectivamente: $\mathrm{Y}=-23,3369+3,1966 \mathrm{X}^{0,5}-4,6074.10^{-}$ ${ }^{2} \mathrm{X}\left(\mathrm{R}^{2}=0,9810\right) ; \mathrm{Y}=-15,1131+1,9799 \mathrm{X}^{0,5}-2,2008.10^{-2} \mathrm{X}\left(\mathrm{R}^{2}=0,9709\right)$ e $\mathrm{Y}=-10,2147$ $+1,3927 X^{0,5}-1,3939 \cdot 10^{-2} X\left(R^{2}=0,9788\right)$, em que $Y$ é a taxa de assimilação de $\mathrm{CO}_{2}$, $\mu \mathrm{mol} \cdot \mathrm{m}^{-2} \cdot \mathrm{s}^{-1}$ e $\mathrm{X}$ a concentração de $\mathrm{CO}_{2}, \mu \mathrm{molCO} \mathrm{CO}_{2} \cdot \mathrm{mol}^{-1}$. Ajustou-se, também, uma equação para taxa de assimilação de $\mathrm{CO}_{2}$ em função da radiação fotossinteticamente ativa: $Y=-4,5221+0,8242 \cdot Z^{0,5}-6,6852 \cdot 10^{-3} \cdot Z\left(R^{2}=0,9535\right)$, sendo $Z$ a radiação fotossinteticamente ativa, $\mu \mathrm{mol} \cdot \mathrm{m}^{-2} \cdot \mathrm{s}^{-1}$.

A aplicação de dióxido de carbono via água de irrigação, em condições de campo, não alterou a qualidade e características químicas do fruto; não provocou diferenças entre os teores de nutrientes nas folhas do meloeiro, exceto para o boro e ocasionou maior eficiência do uso de água. As maiores produtividades obtidas com aplicação de $\mathrm{CO}_{2}$ foram: 38,59 t. ha ${ }^{-1}$ e 37,08 t.ha $^{-1}$. Houve aumento de $70 \%$ na produtividade comercial com uso de $\mathrm{CO}_{2}$ e proteção lateral.

A taxa de assimilação de $\mathrm{CO}_{2}$, em condições de ambiente protegido, foi maior no tratamento com aplicação de $\mathrm{CO}_{2}$, A maior produtividade foi de 28,68 tha ${ }^{-1}$ (aumento de $27,3 \%$ ), obtido com aplicação de $\mathrm{CO}_{2}$. 


\title{
APPLICATION OF CARBON DIOXIDE THROUGH IRRIGATION WATER ON MELON CROP
}

\author{
Author: José Maria Pinto \\ Adviser: Prof. Dr. Tarlei Arriel Botrel \\ Coadviser: Dr. Eduardo Caruso Machado
}

\section{SUMMARY}

The carbon cycle in the biosphere has been significantly altered by man's activities in the last 150 years. The $\mathrm{CO}_{2}$ emitted by human activity is approximately 8,5 billion of tons yearly, as a consequence, the carbon dioxide concentration is increasing. Studies related to the artificial increase effects of $\mathrm{CO}_{2}$ concentration on plants used for obtaining products in greater quantity and with a better quality permit us to know the capacity of the plants to adapt in this environment.

The melon crop is a very important culture of the country, having an outstanding position in the Brazilian horticulture as an export product. Therefore, factors related to the application of carbon dioxide through irrigation water need more accurate studies concerning to carbon dioxide changes. Besides, an adequate dose usage and application periods adapted for different cultures, to reach a maxim benefit cost relationship must be determined.

In this research, the light saturation and photosynthetic point for the melon crop was determined. The $\mathrm{CO}_{2}$ assimilation rate and the productivity were quantified, and the chemical characteristics ( $\mathrm{pH}$, total acidity and soluble solid content) of the melon fruits were evaluated in the harvest and storing. A study about melon crop was carried out in three stages. The first stage, in greenhouse conditions, was performed to determine the answer curves of $\mathrm{CO}_{2}$ assimilation rate in terms of photosyntetically active radiation and $\mathrm{CO}_{2}$ assimilation rate in terms of $\mathrm{CO}_{2}$ concentration. The second stage, in field 
conditions, and the third one, in protected environment conditions, were cultivated with carbon dioxide applied through irrigation water, with the aim to determine its effects on the melon crop production, in the fruit quality and $\mathrm{CO}_{2}$ assimilation rate. The trickle irrigation system was used.

The equations adjusted, in the first stage, for $\mathrm{CO}_{2}$ assimilation rate in terms of $\mathrm{CO}_{2}$ concentration for photosythetically active radiation equal to 850,550 and 300 $\mu$ molm ${ }^{-2} s^{-1}$ were, respectively: $Y=-23,3369+3,1966 X^{0,5}-4,6074 \cdot 10-{ }^{2} X\left(R^{2}=0,9810\right)$; $\mathrm{Y}=-15,1131+1,9799 \mathrm{X}^{0,5}-2,2008 \cdot 10^{-2} \mathrm{X}\left(\mathrm{R}^{2}=0,9709\right)$ and $\mathrm{Y}=-10,2147+1,3827 \mathrm{X}^{0,5}$ $1,3939 \cdot 10^{-2} \mathrm{X}\left(\mathrm{R}^{2}=0,9788\right)$, where $\mathrm{Y}$ is the $\mathrm{CO}_{2}$ assimilation rate, $\mu \mathrm{mol} \cdot \mathrm{m}^{-2} \cdot \mathrm{s}^{-1}$ and $\mathrm{X}$ is the $\mathrm{CO}_{2}$ concentration $\mu \mathrm{molCO} \cdot \mathrm{mol}^{-1}$. Also, an equation was adjusted for $\mathrm{CO}_{2}$ assimilation rate in terms of the photosythetically active radiation: $Y=-4,5221+$ $0,8242 \mathrm{Z}^{0,5}-6,6852 \cdot 10^{-3} \mathrm{Z}\left(\mathrm{R}^{2}=0,9535\right)$, where $\mathrm{Y}$ is $\mathrm{CO}_{2}$ assimilation rate, $\mu \mathrm{mol} \cdot \mathrm{m}^{-2} \cdot \mathrm{s}^{-1}$ and $Z$ is photosythetically active radiation, $\mu \mathrm{mol} \cdot \mathrm{m}^{-2} \cdot \mathrm{s}^{-1}$.

The carbon dioxide application through irrigation water, in field conditions, did not alter the melon crop season, and it did not affect the fruit chemical characteristics, such as soluble solid content, total acidity and $\mathrm{pH}$. There were no differences among content nutrients in melon leaves caused by carbon dioxide, except for boron. The highest yields were 38.59 ton. $\mathrm{ha}^{-1}$ and 37.08 ton. ha ${ }^{-1}$ obtained by carbon dioxide application through irrigation water. There was increase of $70 \%$ in the commercial productivity with $\mathrm{CO}_{2}$ application and lateral protection.

In protected environment conditions, the $\mathrm{CO}_{2}$ assimilation rate was higher in the treatment with $\mathrm{CO}_{2}$ application. The highest yield was 28.68 ton.ha ${ }^{-1}$ ( increase of 27,3 $\%$ ) obtained by carbon dioxide application through irrigation water. 


\section{1- INTRODUÇÃO}

A concentração de $\mathrm{CO}_{2}$ atmosférico tem sido significativamente alterado, era 250 $\mu \mathrm{molCO}{ }_{2} \cdot \mathrm{mol}^{-1}$ antes da revolução industrial, atingiu $350 \mu \mathrm{molCO}_{2} \cdot \mathrm{mol}^{-1} \mathrm{em} 1989$ (Long, 1991), estando, hoje, próximo de $365 \mu \mathrm{molCO}_{2} \cdot \mathrm{mol}^{-1}$, com tendência em aumentar ainda mais (Keeling et al., 1995). continuando sua tendência de aumento, pode chegar a 530 $\mu \mathrm{molCO}{ }_{2} \cdot \mathrm{mol}^{-1}$ em 2050 (Casella et al., 1996). Com este aumento da concentração de dióxido de carbono a temperatura global pode aumentar $4^{\circ} \mathrm{C}$ até o ano de 2100 . Modelos recentemente desenvolvidos mostram que o aumento de temperatura pode ser menor, em torno de $0,2^{\circ} \mathrm{C}$ por década, devido à ação de resfriamento provocada por aerosóis sulfatados (Mitchell et al., 1995).

Atualmente, o dióxido de carbono emitido através da atividade humana é da ordem de 8,5 bilhões de toneladas anuais, sendo que apenas metade desse total permanece na atmosfera. A outra metade acredita-se que seja incorporada pelo solo, florestas (Vitousek, 1991) e oceanos, cujos mecanismos ainda não são completamente esclarecidos (Aiken et al., 1991).

A modernização da produção agrícola tem na adoção de tecnologia instrumento para minimizar os efeitos dos fatores que limitam o processo fisiológico das culturas, aumentar a produtividade, reduzir os custos de produção e melhorar a qualidade do produto obtido. Entre as novas técnicas uma promissora é o uso de dióxido de carbono misturado à água de irrigação está sendo adotado em culturas intensivas, com maior adensamento de plantas por área.

O melão (Cucumis melo L.) é uma das importantes culturas do país, ocupando lugar de destaque na olericultura brasileira, sendo produto de exportação. No Brasil, a 
cultura do melão expandiu-se por várias regiões a partir dos anos 60 e ganhou importância considerável devido ao aumento das áreas plantadas e à alta tecnologia empregada. O cultivo de melão concentra-se na Região Nordeste com $84 \%$ da produção e $57 \%$ da área plantada. Os principais estados produtores são Bahia, Ceará, Pernambuco e Rio Grande do Norte que, a partir de 1989, tornou-se o principal produtor (CODEVASF, 1989).

Parte da produção da região Nordeste destina-se ao mercado interno. O maior consumo está na região Sudeste, obrigando a exportação de frutos para os centros consumidores. Devido ao custo de produção e à qualidade do fruto, outros mercados vêm sendo conquistados, como o europeu e o americano. Os frutos brasileiros chegam à Inglaterra na entressafra espanhola e ocupam até $70 \%$ do mercado. As exportações brasileiras passaram de 2,2 mil toneladas em 1982 para 20,1 mil toneladas em 1989. Duas regiões destacam-se como responsáveis por esse desempenho: o vale do São Francisco e o vale do Açu, ambas no nordeste do país. A maior proximidade do Nordeste com o hemisfério norte (Europa e América do Norte) coloca a região numa posição vantajosa em relação aos demais estados brasileiros, pois reduz os custos de transporte para o escoamento da produção para o mercado consumidor (Dusi, 1992).

Aroma, sabor e aspecto visual são fatores determinantes na qualidade dos frutos de melão, portanto, decisivos na comercialização. A qualidade do melão está também correlacionada ao conteúdo de açúcares. Um bom fruto deve apresentar sabor característico, que é função dos compostos orgânicos produzidos durante o processo de formação e amadurecimento. As condições de cultivo do meloeiro constituem-se num dos fatores de maior influência na qualidade dos frutos. A coloração e as características químicas dependem da adubação, do solo e das condições ambientais do local de produção (Menezes et al., 1995).

A aplicação de gás carbônico nas culturas melhora o metabolismo e o equilíbrio hormonal nas plantas, aumenta a fotossíntese e absorção de nutrientes resultando em plantas mais produtivas, mais resistentes a doenças e ao ataque de pragas, gerando frutos de melhor qualidade (Kimball et al., 1994). 
A técnica de aplicação de gás carbônico já é praticada por agricultores europeus há mais de cem anos. Inicialmente, eles costumavam queimar querosene e propano nas estufas para aumentar a concentração de dióxido de carbono, mas as impurezas produzidas no processo contaminavam as plantas. Atualmente, o dióxido de carbono é ainda obtido por combustão, mas é purificado e engarrafado por indústrias. Além disso, foram desenvolvidos equipamentos e técnicas adequadas para sua aplicação em diversas condições climáticas e de plantio. Na Europa, o gás carbônico é aplicado dentro de estufas. $\mathrm{O}$ dióxido de carbônico pode, também, ser dissolvido na água e levado às plantas por irrigação (Kimball, 1983).

No final dos anos 80 , empresas norte americanas que comercializavam gás carbônico para indústrias, interessaram-se pelo processo na atividade agrícola e iniciaram trabalhos com injeção de gás carbônico na água utilizada para irrigação, em culturas a céu aberto, visando aumentar a sua produtividade com resultados promissores (Idso \& Idso, 1994).

No Brasil, a aplicação de dióxido de carbono via água de irrigação é de uso recente e pouco são os estudos ecofisiológicos referentes às trocas de $\mathrm{CO}_{2}$ em plantas. Existem, ainda, muitos aspectos a esclarecer com relação aos efeitos sobre as plantas, influência na produtividade e na melhoria da qualidade de frutos, doses a serem usadas e períodos de aplicação mais adequados para os diferentes tipos de cultivo, para alcançar uma relação beneficio custo máxima.

Considerou-se como hipótese principal que a aplicação de dióxido de carbono via água de irrigação, ao longo do ciclo da cultura do melão, aumenta a taxa de assimilação de $\mathrm{CO}_{2}$ influindo nos componentes de produção, aumentando a produtividade e melhorando a qualidade dos frutos do meloeiro. Assim, os objetivos deste trabalho foram: determinar o ponto de saturação da taxa de assimilação de $\mathrm{CO}_{2}$ e lumínica para a cultura do melão; quantificar a taxa de assimilação de $\mathrm{CO}_{2}$ e a produtividade e avaliar as características químicas ( $\mathrm{pH}$, acidez total e teor de sólidos solúveis, ${ }^{\circ} \mathrm{Brix}$ ) dos frutos de melão na colheita e, durante o armazenamento, dez, vinte e trinta dias após a colheita em decorrência da aplicação de dióxido de carbono via água de irrigação. 


\section{2- REVISÃO DE LITERATURA}

A produção agrícola é o resultado da ação integrada da planta e meio ambiente. Cabe ao solo fornecer as condições necessárias ao desenvolvimento das plantas incluindo água e nutrientes. À planta cabe contribuir com o potencial genético, enquanto a atmosfera provê a luz, o calor, o $\mathrm{O}_{2}$ e o $\mathrm{CO}_{2}$ entre outros.

Estudos relacionados aos efeitos causados pelo aumento da concentração de dióxido de carbono sobre as plantas, segundo Mudrik et al. (1997) são interessantes por dois aspectos. Primeiro, cultivar plantas em casa de vegetação, com aumento artificial da concentração de dióxido de carbono, está sendo usado para obtenção de produtos em maior quantidade e melhor qualidade; segundo, estudar o comportamento das plantas em ambientes com elevada concentração de dióxido de carbono, uma vez que a concentração atmosférica está aumentando, possibilitando conhecer a capacidade das plantas de adaptarem-se a esses ambientes. No entanto, o efeito do aumento da concentração de dióxido de carbono na atmosfera difere das condições de casa de vegetação em escala de tempo e desenvolvimento. $\mathrm{Na}$ atmosfera a elevação é ínfima e lenta, o que permite às plantas alterações de comportamento e, até adaptações genéticas para altas produções em tais ambientes (Chmora \& Mokronosov, 1994).

O papel da hidrosfera no mecanismo de absorção de dióxido de carbono atmosférico é de vital importância, pois esta cobre sete décimos da superficie da terra. As águas oceânicas superficiais estão tendo um incremento de $1 \mu \mathrm{mol} \cdot \mathrm{kg}^{-1}$.ano ${ }^{-1}$ em relação ao dióxido de carbono total (Guimarães, 1995).

Um dos primeiros trabalhos sobre aplicação de dióxido de carbono na Agricultura foi publicado em 1918 com o interessante título "Fertilização da antena das plantas com 
dióxido de carbono", por Cummings \& Jones ${ }^{1}$, citado por Moore (1990). A aplicação de dióxido de carbono vem sendo utilizada em casa de vegetação há vários anos para acelerar o crescimento e incrementar a produtividade das culturas.

Em condições de campo, a aplicação de dióxido de carbono pode ser viável em culturas com sistema de irrigação em implantado e em funcionamento, em cultivos de alto valor econômico, porte baixo e culturas com intensa densidade foliar. Irrigação com aplicação de $\mathrm{CO}_{2}$ aumenta a sua concentração tanto no micro-ambiente das plantas quanto no ar do solo, na zona do sistema radicular e aumenta, também, a concentração de bicarbonato na solução do solo, alterando as atividades microbiológicas e o pH, influindo na absorção de nutrientes pelas raizes das plantas (Moore, 1990).

Diferentes espécies de plantas reagem de forma distinta em ambientes com alta concentração de dióxido de carbono. $\mathrm{O}$ teor de nitrogênio e o conteúdo de tanino nas folhas variam e o ataque de insetos é alterado. Larvas desenvolvem-se menos em ambientes com maior concentração de dióxido de carbono, as fêmeas são mais afetadas que os machos (Traw et al., 1996).

O efeito do dióxido de carbono foi maior no verão que no inverno. No verão verificou-se ocorrência de déficit hídrico antes que no inverno. Além de que, microrganismos da rizosfera das plantas segregam ácidos orgânicos que aceleram a degradação química dos minerais do solo, especialmente fósforo, tornando-os disponiveis para as plantas. Como "feedback", os microrganismos também produzem hormônios que estimulam o crescimento das raízes, induzindo a produção de mais raizes laterais (Babenko et al., 1985; Casella et al., 1996).

O enriquecimento da atmosfera com dióxido de carbono fez com que certas plantas fossem capazes de absorver nutrientes escassos com mais eficiência (Norby et al., 1986). Como a absorção desses nutrientes requer dispêndio de energia, o aumento de carboidratos disponiveis proporcionados pela elevada concentração de dióxido de carbono melhora o processo de absorção de nutrientes (Rufty et al., 1989).

\footnotetext{
${ }^{1}$ CUMMINGS, M. B.; JONES, C. H. The Aerial fertilization of with carbon dioxide. (s.1.):Vermont Station, 1918. 56p. (Agriculture Experimental Station. Bulletin, 211).
} 


\section{1- Efeito do dióxido de carbono sobre as plantas}

Nos últimos 15 anos, estudos experimentais indicaram que a absorção de carbono para fotossintese aumentou em plantas cultivadas em ambientes com alta concentração de $\mathrm{CO}_{2}$. Algumas espécies florestais aumentaram a fotossíntese em $44 \%$. Houve, também, aumento da biomassa do sistema radicular. Com maior desenvolvimento do sistema radicular, aumenta o volume de solo para extração de água e nutrientes, reduzindo as limitações de nutrição das plantas. $\mathrm{O}$ incremento da biomassa do sistema radicular pode induzir maior expiração de dióxido de carbono e exudação de substâncias, estimulando as atividades microbiológicas no solo (Luo et al., 1994). Segundo Mudrik et al. (1997) em experimentos com curtos períodos de tempo de aplicação de dióxido de carbono, 0 aumento da concentração aumentou a fotossintese em até $52 \%$ em plantas $C_{3}$ e $29 \%$ na produção. Entretanto, períodos prolongados de exposição de plantas em altas concentrações de dióxido de carbono podem causar fechamento de estômatos, maior produção de etileno e desenvolvimento de doenças (Cure \& Acock, 1986).

Há variação entre espécies de plantas $C_{3}$ em relação à fotossíntese, crescimento vegetativo, massa foliar e desenvolvimento do sistema radicular quando desenvolvidas em ambientes enriquecidos com dióxido de carbono. Efeitos comumente observados são: redução da concentração de nitrogênio nos tecidos das folhas devido à baixa taxa de transpiração; aumento de carboidratos; modificação da distribuição de proteínas e compostos nitrogenados e aumento da massa fresca das folhas (Vessey et al., 1990). Gao \& Zhang (1997) observaram aumento variando de 13 a 32\% em algumas espécies florestais quando dobraram a concentração de $\mathrm{CO}_{2}$. Plantas $\mathrm{C}_{3}$ aumentaram seu desenvolvimento vegetativo em $41 \%$, as $\mathrm{C}_{4}$ em $22 \%$ e as CAM em 5\%, quando a concentração de $\mathrm{CO}_{2}$ foi de aproximadamente $700 \mu \mathrm{molCO}_{2} \cdot \mathrm{mol}^{-1}$ (Wong, 1979; Poorter, 1993; Fischer et al., 1997; Soussana et al., 1996). Variando a concentração de $\mathrm{CO}_{2}$ e intensidade luminosa, Ghannoum et al. (1997) encontraram variação no peso seco de $71 \%$ para plantas $\mathrm{C}_{3}$ e $28 \%$ em plantas $\mathrm{C}_{4}$. A magnitude do incremento depende da temperatura. Quanto menor a temperatura menor o efeito. O aumento da velocidade de assimilação pode atingir $80 \%$ ao ativar a enzima ribulose 1,5 bisfosfato carboxilase- 
oxigenase (Rubisco), reduzindo a fotorrespiração, melhorando o metabolismo, o crescimento e a produção. A temperatura ótima para fotossíntese varia com o estádio de desenvolvimento das plantas, estando na faixa de 20 a $30^{\circ} \mathrm{C}$ para a maioria das plantas, sendo menor na fase de maturação (Acock et al., 1990).

A concentração de nitrogênio por unidade de massa nos tecidos vegetais sempre decresce em ambiente com elevada concentração de dióxido de carbono de 2 a 57\%, dependendo da espécie, conseqüência do aumento de carboidratos e diminuição de Rubisco e de proteínas (Luo et al., 1996).

Vários estudos conduzidos com o enriquecimento de dióxido de carbono em ambientes controlados e em condições de campo mostram o aumento na fotossíntese, no desenvolvimento dos vegetais e resistência ao estresse hídrico, o que pode ser explicado pela absorção de dióxido de carbono pelas raízes e conseqüente aumento na assimilação pelo metabolismo das plantas (Arteca et al., 1979; Baron \& Gorsky, 1986; Cooker \& Schubert, 1981; Guinn, 1974). Entretanto, Arteca \& Poovaiah, (1982) observaram que apenas $0,1 \%$ do carbono total fixado pela fotossíntese é absorvido pelas raízes. Outra explicação é que a absorção de dióxido de carbono pelas raizes influencia o equilíbrio hormonal afetando os processos fisiológicos. Combinações equilibradas de etileno e dióxido de carbono no ar do solo podem reduzir os efeitos prejudiciais do etileno no desenvolvimento das raízes e, também, aumentam a concentração de bicarbonatos na solução do solo (Finn \& Brun, 1982).

A sensibilidade das trocas do $\mathrm{CO}_{2}$ à deficiência hídrica é uma característica da espécie, sendo porém adaptável. Esta sensibilidade depende ainda da idade da planta, da posição de ramos e folhas na copa da árvore e da umidade do solo (Larcher, 1995). Plantas submetidas à estresses hídricos freqüentes respondem melhor à maiores concentrações de dióxido de carbono (Ham et al., 1995). O aumento da concentração de dióxido de carbono causa fechamento parcial dos estômatos, causando, como conseqüência, redução na transpiração (Faquhar et al., 1978; Kimball, 1983; Kimball \& Idso, 1983; Morison, 1985; Cure \& Acock, 1986). Nesta situação há aumento da taxa de crescimento, com produção de maior quantidade de matéria vegetativa e aumento na área foliar (Morison \& Gifford, 1984). Mesmo em condições de luminosidade inadequada e 
deficiência hídrica, a taxa de crescimento das plantas é aumentada em ambientes com alta concentração de dióxido de carbono, que ocorre devido ao fechamento dos estômatos e maior expansão do sistema radicular, possibilitando a exploração de um maior volume de solo (Curtis et al., 1990).

A produtividade das culturas diminui com decréscimo de luminosidade (Moore, 1991). Aumentos na taxa de crescimento causados pelo aumento da concentração de $\mathrm{CO}_{2}$ são menores em ambientes com baixa luminosidade. Entretanto, o comportamento das plantas pode variar, 50\% têm seu crescimento acelerado em ambientes enriquecidos com dióxido de carbono e baixa luminosidade, enquanto $40 \%$ reduzem o crescimento quando a concentração de dióxido de carbono aproxima-se de $700 \mu \mathrm{molCO}_{2} \cdot \mathrm{mol}^{-1}$, ocorrendo, também, atraso no período de colheita (Idso \& Brazel, 1984; Putkhal'skaya, 1997).

Folhas expostas por determinado período a elevada concentração de dióxido de carbono sofrem mudanças químicas em sua composição. A concentração total de carboidratos geralmente aumenta a concentração de nitrogênio e a capacidade fotossintética diminuem (Körner \& Würth, 1996).

A simbiose de fungos em ambientes enriquecidos com dióxido de carbono pode prolongar a vida dos pêlos absorventes por alguns dias, aumentando a área de absorção de nutrientes das raízes (Tinker, 1984).

$\mathrm{O}$ uso de $\mathrm{CO}_{2}$, sob a forma de gás ou misturado à água de irrigação, melhora a qualidade das flores e frutos. $\mathrm{O} \mathrm{CO}_{2}$ reage com os cations da solução do solo produzindo bicarbonatos, os quais são absorvidos pelas plantas (Smith et al., 1991). O CO CO $_{2}$ provoca, ainda, redução do $\mathrm{pH}$ do solo, aumenta a disponibilidade de fósforo e cálcio na solução do solo e favorece a absorção de zinco e manganês. No algodão aumentou o crescimento vegetativo e o tamanho do capulho (Mauney \& Hendrix, 1988). Todavia, o $\mathrm{pH}$ tende a retornar aos valores anteriores 24 horas após a aplicação (Basile et al., 1993). Mesmo em solo com limitação nutricional pode ocorrer maior desenvolvimento do sistema radicular, o que permite maior absorção de nutrientes e intensifica a translocação de produtos fotossintetizados das folhas para as raízes (Norby et al., 1992). Ghannoum et al. (1997) constataram maior número de sementes em ambiente enriquecido com $\mathrm{CO}_{2}$, em Panicum laxum e Panicum antidotale. D'Andria et al. (1990) observaram aumento na produção de 
tomates, não com maior número de frutos e sim frutos maiores, em cultivos com solo coberto por plástico e irrigado por gotejamento.

A elevação da concentração de dióxido de carbono para aproximadamente 1000 $\mu \mathrm{molCO} 2 \cdot \mathrm{mol}^{-1}$ em Digitalis lanata, cultivada em estufa, produziu aumento de duas vezes mais biomassa em comparação ao cultivo em condições de campo, sem aplicação de dióxido de carbono. $\mathrm{O}$ aumento da concentração de dióxido de carbono estimulou o metabolismo primário de duas maneiras: estimulação da carboxilação da ribulosebifosfato e redução da fotorrespiração. Entretanto, (Stuhlfauth \& Fock, 1990) advertem que a manutenção da concentração de dióxido de carbono em casa de vegetação deve superar duas dificuldades: elevadas temperaturas, que afetam a fotossíntese e a perda de dióxido de carbono com a abertura da estufa para resfriamento.

\section{2- Outras aplicações do dióxido de carbono na Agricultura}

A atmosfera controlada também pode ser benéfica na conservação de frutos após a colheita, embora existam poucas pesquisas com melão. Resultados obtidos por Stewart (1979), em Cantaloupe 'PMR 45', indicaram que atmosfera enriquecida com dióxido de carbono a $20 \%$ reduziu a severidade de ataque fúngico, danos superficiais e degradação da polpa quando comparada com atmosfera comum. $\mathrm{O}$ efeito foi mais benéfico ocorreu após a manutenção dos frutos por 14 dias a $5^{\circ} \mathrm{C}$, seguido de três dias em ambiente a $20^{\circ} \mathrm{C}$. O armazenamento dos frutos em atmosfera com $40 \%$ na concentração de $\mathrm{CO}_{2}$ provocou danos fisiológicos, com alteração de sabor e liberação de odor desagradável.

Estudos realizados por Aharoni et al. (1993), com atmosfera controlada em melão 'Galia', indicaram que o dióxido de carbono a $20 \%$ mostrou-se mais efetivo do que as concentrações a $5 \%$ ou $10 \%$, no entanto, provocou mudanças de sabor e aroma. A combinação de $10 \%$ de dióxido de carbono e $10 \%$ de $\mathrm{O}_{2}$ prolongou a armazenabilidade do fruto sem causar prejuízos de sabor e aroma. Todavia, atmosfera enriquecida com $10 \%$ de $\mathrm{CO}_{2}$ e $10 \%$ de $\mathrm{O}_{2}$, com aplicação de etileno, é a condição propícia para 
armazenamento de melão, sem problemas de amolecimento dos frutos e incidência de ataque de fungos, ou mesmo, sem mudanças do sabor e aroma.

\section{3- Aspetos gerais da cultura do melão}

O melão (Cucumis melo L.) é uma planta poliformórfica, da família Cucurbitácea, do gênero Cucumis e espécie Cucumis melo L, cujas formas botânicas diferenciam-se quanto: aspectos de sensibilidade ao frio; atividade metabólica; forma e tamanho de fruto; estrutura da casca e polpa de acordo com a variedade cultivada (Menezes, 1996). Nagai (1987) afirma que o melão é originário da África. Para Sampaio e Yamashiro ${ }^{2}$, citados por Araújo (1979), o melão tem origem incerta, podendo ter sido originário da Ásia (China ou Índia). O gênero Cucumis, assim como Cucumis melo tem origem africana. Os grupos mais importantes de melão são: reticulatus, cantalupensis e inodorus, no qual está incluído o melão amarelo. Os frutos têm a polpa suculenta e adocicada e são consumidos frescos (Casali et al., 1982). Araújo (1979), informa que o melão foi introduzido na Itália, 300 anos após a Era Cristã, na França no século XV e na América na época do descobrimento por Cristóvão Colombo.

Originário de regiões tropicais, a qualidade e a produtividade do meloeiro são afetadas pelo clima. Em altas temperaturas e baixa umidade relativa do ar, o fruto de melão contém: maior teor de açúcar; sabor e aroma mais agradáveis; maior consistência e melhor conservação (Filgueira, 1981). O m eloeiro é uma planta exigente em temperaturas diurnas e noturnas altas, tanto do ar como do solo. A faixa de temperatura ideal está entre 25 e $32^{\circ} \mathrm{C}$ durante todo o ciclo da cultura. Temperatura abaixo de $18^{\circ} \mathrm{C}$ dificulta a abertura das flores. Todavia, essa é a temperatura do solo mais favorável à germinação das sementes. Com temperatura do ar abaixo de $15^{\circ} \mathrm{C}$ e do solo inferior a $18^{\circ} \mathrm{C}$, a planta pode ter seu desenvolvimento paralisado. Temperatura elevada estimula o aparecimento de maior número de flores masculinas mas, se acompanhada de ventos quentes, provoca distúrbios fisiológicos que resultam em rachadura da casca do fruto. Temperatura acima de $35^{\circ} \mathrm{C}$ pode afetar a floração e a frutificação (Silva, 1982). 
Aumento de temperatura do solo de 25 para $35^{\circ} \mathrm{C}$ estimulou o crescimento dos frutos de melão e acelerou o desenvolvimento da planta (Souza, 1993). Frutos de melão colhidos e mantidos em altas temperaturas amadurecem rapidamente e ocorre perda do conteúdo de açúcar, diminuindo seu valor comercial. Entretanto, em temperaturas entre 1,1 a $4,4^{\circ} \mathrm{C}$ reduzem sua taxa de amadurecimento e perdas de açúcar, aumentando a qualidade e a resistência ao transporte (Ermland Junior, 1986; Fuentes, 1988).

A densidade de plantas tem influência no número e tamanho de frutos do meloeiro (Davis \& Meinert, 1965). O sistema de condução e o desbaste na cultura do melão influem na qualidade e na uniformidade dos frutos. Recomenda-se deixar três ramos por planta e um fruto por ramo. Deve-se eliminar as flores, desbrotar os ramos secundários até o quinto nó e escolher frutos formados entre o quinto e oitavo nó. Entretanto, poda de ramos e desbaste de frutos são operações que acarretam aumento no custo de produção, contudo, pode ser compensado pela melhor qualidade do fruto e conseqüentemente maior aceitação pelo consumidor (Filgueira, 1981). Deve-se lembrar que em áreas de plantio comercial nem sempre é possível realizar esta prática, principalmente em grandes áreas, pois o período de tempo propício para sua realização é curto.

Além dos fatores climáticos, tipo de solo, espaçamento entre plantas, densidade de plantio e tratos culturais, o número de flores masculinas e femininas e sua polinização respondem pela produção de frutos. A polinização depende da presença de abelhas. A produção é reduzida quando o número de abelhas em atividades é pequeno. A polinização deficiente das flores produz frutos deformados, ou provoca queda desses logo após o início do seu desenvolvimento. Em cultura conduzida em estufa pode ser necessário fazer polinização artificial, que deve ser realizada pela manhã quando as flores encontram-se totalmente abertas (Souza, 1993).

A absorção de nutrientes acompanha a produção de matéria seca, conforme atestam Tyler \& Lorenz (1964). As quantidades extraídas de nitrogênio e potássio foram quatro vezes maiores do que fósforo e cálcio e duas vezes o magnésio. A produção de matéria seca e a absorção de nutrientes foram mais rápidas no período compreendido 
entre o início da floração e a colheita. Os valores extraídos por hectare foram: $135 \mathrm{~kg}$ de nitrogênio, $20 \mathrm{~kg}$ de fósforo, $158 \mathrm{~kg}$ de potássio, $27 \mathrm{~kg}$ de cálcio e $38 \mathrm{~kg}$ de magnésio.

A disponibilidade de nutrientes é fator decisivo na produção e qualidade de frutos de melão. A absorção de nitrogênio e potássio foi cinco vezes maior que a de fósforo e cálcio e três vezes a do magnésio. Embora aumento da quantidade de nitrogênio implique em maior concentração de nitrogênio, zinco e manganês no tecido, faz com que diminua a concentração de cálcio, magnésio e boro (Bhella \& Wilcox, 1986).

A adubação potássica tem importância na produção, principalmente na qualidade de frutos, melhorando o teor de sólidos solúveis. $\mathrm{O}$ aumento na produção é devido ao aumento do tamanho dos frutos (Prabhakar et al., 1985).

A absorção de nitrato e de cálcio ocorre na fase inicial de crescimento da cultura do meloeiro, enquanto que a absorção de potássio é maior durante a frutificação e amadurecimento dos frutos (Souza, 1993; Hughes \& Yamaguchi, 1983).

O melão caracteriza-se como uma cultura de sistema radicular superficial, com profundidade efetiva, em solos arenosos, em torno de 0,25 m (Macgilivrai, 1951; Souza, 1993; Pinto et al., 1996), próximo dos valores encontrados por Hernandez (1995) que foram de 78,18 a $84,03 \%$ na camada de 0 a $0,10 \mathrm{~m} ; 9,10$ a $15,11 \%$ na camada de 0,10 a $0,20 \mathrm{~m}$ e 3,20 a $9,66 \%$ na camada de 0,20 a $0,30 \mathrm{~m}$, porém, diferentes dos resultados encontrados por Marouelli et al. (1989) compreendidos entre 0,50 e 1,20 m. A concentração das raízes na camada superficial do solo deve-se provavelmente ao tipo de sistema de irrigação e a compactação do solo. Se a cultura for irrigada por aspersão, provavelmente o perfil de distribuição será outro..

A cultura do melão adapta-se bem ao método de irrigação por gotejamento, que não molha a parte aérea das plantas. As irrigações devem ser realizadas diariamente ou até duas vezes ao dia, dependendo da capacidade de retenção de água pelo solo (Goldberg \& Shmueli, 1970).

O manejo da irrigação pode ser realizado através do controle da tensão de água no solo, necessitando assim, conhecer a tensão ideal para cada fase da cultura durante seu ciclo de desenvolvimento. No caso do meloeiro a tensão de água no solo pode variar entre 50,7 e 60,6 kPa, sem causar perdas consideráveis na produção e alta eficiência de 
uso de água (Battikhi \& Hill, 1988). Para as condições da região do sub-médio do São Francisco, Choudhury \& Faria (1982) não encontraram redução na produção trabalhando com tensão de água no solo variando de 30 a $60 \mathrm{kPa}$. A eficiência do uso de água é um parâmetro de rendimento total da colheita por unidade de água utilizada. Tanto a produção biológica ou a de frutos e a quantidade evapotranspirada são dependentes do balanço de energia e a eficiência do uso da água, que por sua vez é dependente da energia na cultura (Begg \& Turner 1976).

A tensão de água no solo deve ser monitorada a uma profundidade de $0,15 \mathrm{~m}$, através de tensiômetros (Ells et al., 1989). Para uma unidade de irrigação deve-se instalar os medidores de tensão em pelo menos três pontos representativos da área, sendo o controle da irrigação realizado pela média das leituras (Marouelli et al., 1989). A quantidade de água a ser aplicada por irrigação pode ser calculada considerando-se os seguintes valores de coeficiente de cultivo $(\mathrm{kc}): 1^{\mathrm{a}}$ quinzena $\mathrm{kc}=0,75 ; 2^{\mathrm{a}}$ quinzena $\mathrm{kc}=$ 0,$85 ; 3^{\mathrm{a}}$ e $4^{\mathrm{a}}$ quinzenas $\mathrm{kc}=1,15$, após a primeira colheita $\mathrm{kc}=0,75$ (Pinto et al. 1994). Doorenbos \& Pruit (1976) sugerem, para a cultura do melão os seguintes kc: fase inicial 0,5 ; desenvolvimento vegetativo - 1,1; florescimento e frutificação - 1,2; colheita - 0,7.

Deve-se evitar o contato da água com o caule da planta, prevenindo, dessa maneira, a formação de microclimas úmidos, que favorecem o aparecimento de doenças, principalmente a micosferela e o cancro das hastes. $O$ efeito de irrigação excessiva possibilita a disseminação de doenças e perda na qualidade dos frutos, afeta, também a resistência ao transporte (Ferreira et al., 1982).

Em estudo realizado em Israel, comparando os métodos de gotejamento, sulco e aspersão em melão, obteve-se produtividades iguais a 43,0, 24,2 e 23,8 th. ha ${ }^{-1}$, respectivamente. $\mathrm{O}$ crescimento vegetativo foi mais rápido no melão irrigado por gotejamento (Halevy et al., 1973).

Em melão cultivado com irrigação por gotejamento, observou-se o efeito de diferentes intervalos entre irrigações de cinco, três e um dia. Verificou-se produtividade, 34 t.ha ${ }^{-1}$ com irrigação diária, contra 29 t.ha $^{-1}$ com irrigação a cada cinco dias. Há precocidade de produção do melão irrigado por gotejamento. Em comparação com os demais métodos de irrigação, a colheita do melão irrigado por gotejamento foi realizada 
duas semanas antes que nas áreas irrigadas por aspersão e uma semana antes que nas áreas irrigadas por sulco (Goldberg et al., 1976).

A eficiência da irrigação localizada, combinada com a fertirrigação, promove a melhoria da eficiência do uso dos fertilizantes, reduzindo perdas dos nutrientes por lixiviação, condicionando a um melhor controle da concentração de nutrientes no solo e economizando mão-de-obra e energia, quando comparado com outros sistemas de fornecimento de água e fertilizantes às plantas (Pizarro, 1990). Miller et al. (1981) comentam que a aplicação de fertilizantes por gotejamento é apropriada devido ao fornecimento de água com alta freqüência e diretamente na zona radicular das plantas.

A condição de cultivo do meloeiro constitui fator de grande influência na qualidade dos frutos. A coloração e as características organolépticas são dependentes da adubação, do solo, do clima e da disponibilidade hídrica, o que melhora a qualidade dos frutos e conseqüentemente seu valor comercial, como também sua resistência ao transporte e armazenamento (Costa, 1987).

A qualidade de frutos está correlacionada com o conteúdo de açúcares. Um fruto bom deve apresentar sabor característico, que é função dos compostos orgânicos produzidos durante o amadurecimento. Alguns desses compostos foram identificados e muitos deles são álcoois e ésteres de ácidos (Vieira, 1984).

Em melão, o termo qualidade tem sido relacionado a diferentes fatores. Uma das características mais estudadas é o conteúdo de sólidos solúveis. O conteúdo de sólidos solúveis, definido como a percentagem de sólidos solúveis no suco da polpa, é um fator usado para determinar a qualidade de frutos (Bosland et al., 1979). O conteúdo de sólidos solúveis nem sempre é um bom indicador de qualidade, o aroma e o sabor deveriam ser fatores de qualidade complementares para avaliação da qualidade de frutos (Aulenbach \& Worthington, 1974).

A qualidade do melão é influenciada por fatores de pré-colheita, como práticas de irrigação e aplicação de nitrogênio (Flocker et al., 1965), método de plantio (Bhella \& Wilcox, 1989), umidade do solo (Wells \& Nugent, 1980), propriedades fisicas do solo (Davis Jr. \& Schweers, 1971) e insolação (Forney, 1990). A presença de microorganismos que atacam frutos e folhas, reduz a área foliar e possibilita a queima do 
fruto pela radiação solar. Frutos provenientes dessas plantas amadurecem prematuramente e apresentam baixa qualidade quando comparados com aqueles provenientes de plantas sadias (Menezes, 1996).

A densidade de plantio e a qualidade da água de irrigação são fatores que afetam a qualidade do fruto do meloeiro. Aumento da densidade de plantio diminuiu a percentagem de sólidos solúveis, enquanto aumento da salinidade correlacionou-se positivamente com teor de sólidos solúveis (Mendlinger, 1994).

Fatores ligados diretamente à colheita, como danos mecânicos, horário de colheita, permanência dos frutos no campo após a colheita durante o dia, em regiões de temperaturas altas, ou durante a noite quando a umidade relativa é alta, são aspectos a serem considerados na obtenção de frutos de boa qualidade (Foster et al., 1979).

O principal fator ambiental que influencia a qualidade pós-colheita do melão é a estação de cultivo. Os melões cultivados em Israel durante o inverno são susceptíveis à degradação da polpa, caracterizada pelo amolecimento dos tecidos, começando na cavidade das sementes e resultando na degradação do fruto como um todo. Os frutos cultivados no outono não apresentam sintomas dessa desordem, cujos fatores não são, ainda, conhecidos (Mizrach et al., 1994). 


\section{3- MATERIAL E MÉTODOS}

A pesquisa foi realizada em três etapas. A primeira etapa foi conduzida na Seção de Fisiologia, no Centro Experimental de Campinas, do Instituto Agronômico de Campinas - IAC em Campinas, SP, onde foram determinadas curvas de resposta da taxa de assimilação de $\mathrm{CO}_{2}$ em função do fluxo de fotons fotossinticamente ativos (PAR) e da concentração de $\mathrm{CO}_{2}$.

A segunda etapa, conduzida em condições de campo, e a terceira, em condições de casa de vegetação coberta com plástico transparente e laterais confeccionada com tela de nylon, sem controle de temperatura e umidade relativa (ambiente protegido), foram realizadas na área experimental de agricultura irrigada da Fazenda Areão, pertencente à Escola Superior de Agricultura 'Luiz de Queiroz", unidade da USP, em Piracicaba, SP, com a cultura do melão para avaliar os efeitos da aplicação de $\mathrm{CO}_{2}$ via água de irrigação na produtividade e qualidade dos frutos.

\section{1- Curvas de respostas da taxa de assimilação de $\mathrm{CO}_{2}$ à concentração de dióxido de carbono e ao PAR}

Um conjunto de plantas foi utilizado para determinar as curvas de resposta da fotossíntese à concentração de $\mathrm{CO}_{2}$ e ao PAR em meloeiro, crescido em condições de casa de vegetação, no IAC. 
A semeadura foi feita em vinte vasos de 2,5 litros de volume, preenchidos com uma mistura de dois terços de solo e um terço de areia, colocada sobre uma camada de cinco centímetros de brita zero. Colocou-se três sementes por vaso em semeadura realizada em 21/01/96. Uma semana após a germinação foi feito desbaste, deixando uma planta por vaso. Realizou-se, no Laboratório de Nutrição Mineral de Plantas da ESALQ, análise química do solo cujos resultados são apresentados na Tabela 1.

Tabela 1. Análise química do solo utilizado no experimento em vasos.

\begin{tabular}{cccccccccc}
\hline $\mathrm{pH}$ & $\mathrm{M} . \mathrm{O}$ & $\mathrm{P}$ & $\mathrm{K}$ & $\mathrm{Ca}$ & $\mathrm{Mg}$ & $\mathrm{H}+\mathrm{Al}$ & $\mathrm{S}$ & $\mathrm{T}$ & $\mathrm{V}$ \\
\hdashline $\mathrm{CaCl}$ & $\mathrm{g} \cdot \mathrm{kg}^{-1}$ & $\mathrm{mg} \cdot \mathrm{kg}^{-1}$ & $\ldots \ldots \ldots \ldots \ldots \ldots \ldots \ldots$ & $\mathrm{mmol}_{\mathrm{c}} \mathrm{L}^{-1}$ & $\ldots \ldots \ldots \ldots \ldots \ldots \ldots \ldots \ldots$ & $\%$ \\
\hline 5,4 & 19,4 & 164,9 & 2,3 & 57,1 & 8,4 & 30,8 & 68 & 99 & 68,8 \\
\hline
\end{tabular}

A adubação de plantio, efetuada conforme recomendação baseada na análise química do solo, constituiu-se de seis gramas de $\mathrm{P}_{2} \mathrm{O}_{5}$, seis gramas de nitrogênio e dezoito gramas de potássio por vaso. No início do florescimento foi feita uma adubação de cobertura aplicando-se cinco gramas de nitrogênio em cada vaso.

No início do estádio de frutificação foram realizadas as determinações da taxa de assimilação de $\mathrm{CO}_{2}$ em folhas individuais. As plantas intactas eram transportadas para o laboratório e colocadas sob um sistema de iluminação, cujos detalhes são apresentados na Figura 1. A taxa de assimilação de $\mathrm{CO}_{2}$, a radiação e a concentração interna e externa de $\mathrm{CO}_{2}$ da folha foram determinadas com um analisador portátil e fotossíntese por radiação infravermelha, LI 6200 da Licor, IRGA (Figuras 2 e 3). Neste equipamento a fotossíntese foi determinada num sistema fechado. Para determinação da curva de resposta de fotossíntese seguiu-se o método descrito por McDermitt et al. (1989). Colocou-se a folha na câmara do aparelho e injetou-se $\mathrm{CO}_{2}$ até o valor de aproximadamente 1200 $\mu \mathrm{molCO}_{2} \cdot \mathrm{mol}^{-1}$ por meio de uma seringa de injeção e mediu-se sucessivamente a fotossíntese a cada decréscimo de $5 \mu \mathrm{molCO}_{2} \cdot \mathrm{mol}^{-1}$ até seu valor aproximar-se de zero. 
As medidas foram realizadas num periodo de três dias. Os dados foram coletados em três niveis de PAR, ou seja: 850,550 e $300 \mu \mathrm{mol} \cdot \mathrm{m}^{-2} \cdot \mathrm{s}^{-1}$.

Para quantificação do ponto de saturação luminica, a variação do PAR recebido pelas folhas foi obtida fazendo-se variar a posição do vaso em relação à fonte de luz, constituída por um sistema formado por um conjunto de lâmpadas de mercúrio (Figura 1). A luz atravessava uma lâmina de água circulante para absorver a radiação infravermelha, evitando o aumento excessivo de temperatura no ambiente das plantas.

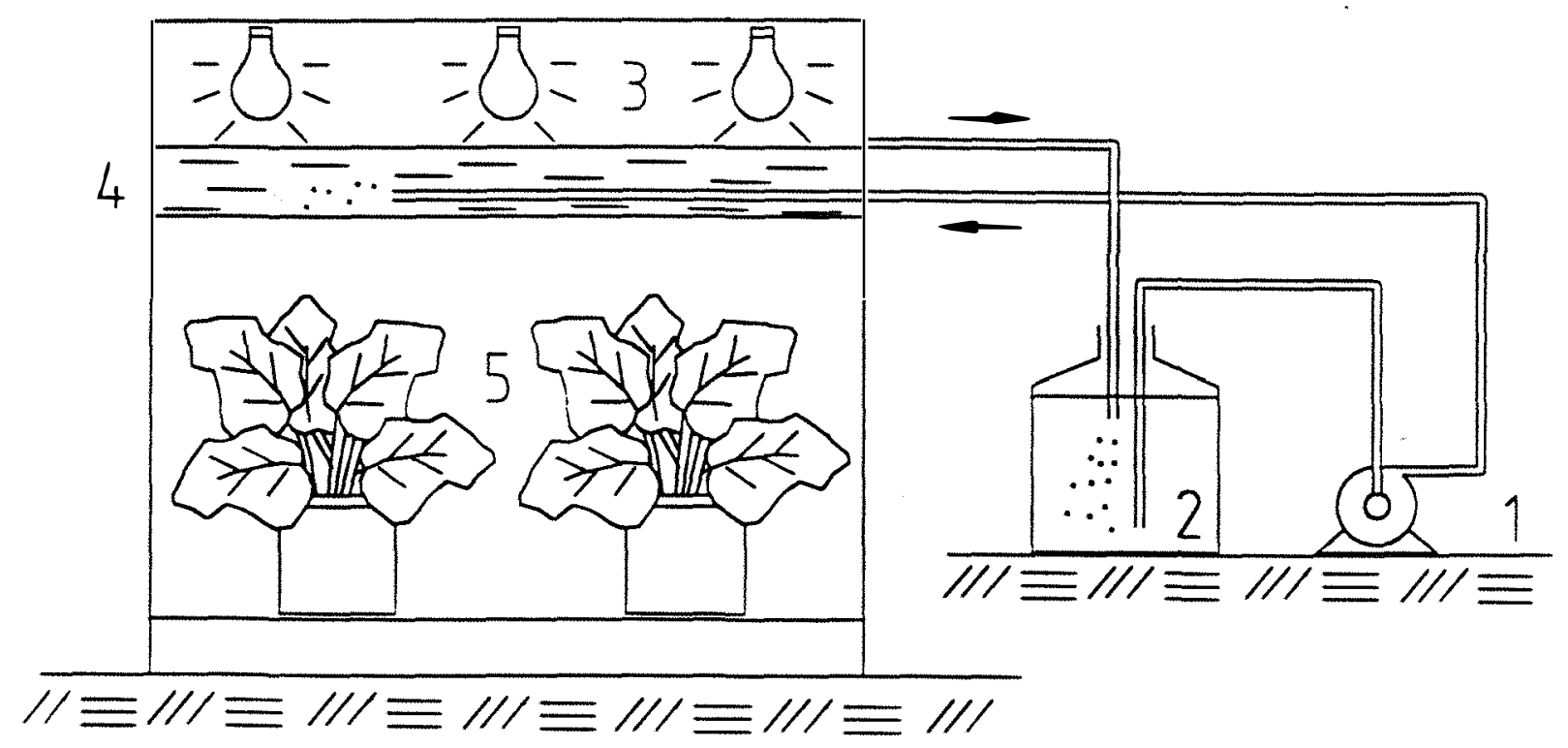

Figura 1 - Esquema do sistema utilizado para controlar a intensidade de radiação fotossinteticamente ativa.

1. Bomba de água; 2. recipiente de água; 3 . sistema de iluminação; 4. filtro de água para atenuação da radiação infravermelha; 5 . planta.

Todas as determinações foram feitas em quatro plantas, sorteadas dos vintes vasos cultivados. Selecionou-se uma folha recém-madura de cada planta, localizada após a primeira flor masculina, sendo que todas as determinações foram realizadas sempre na mesma folha de cada planta. 


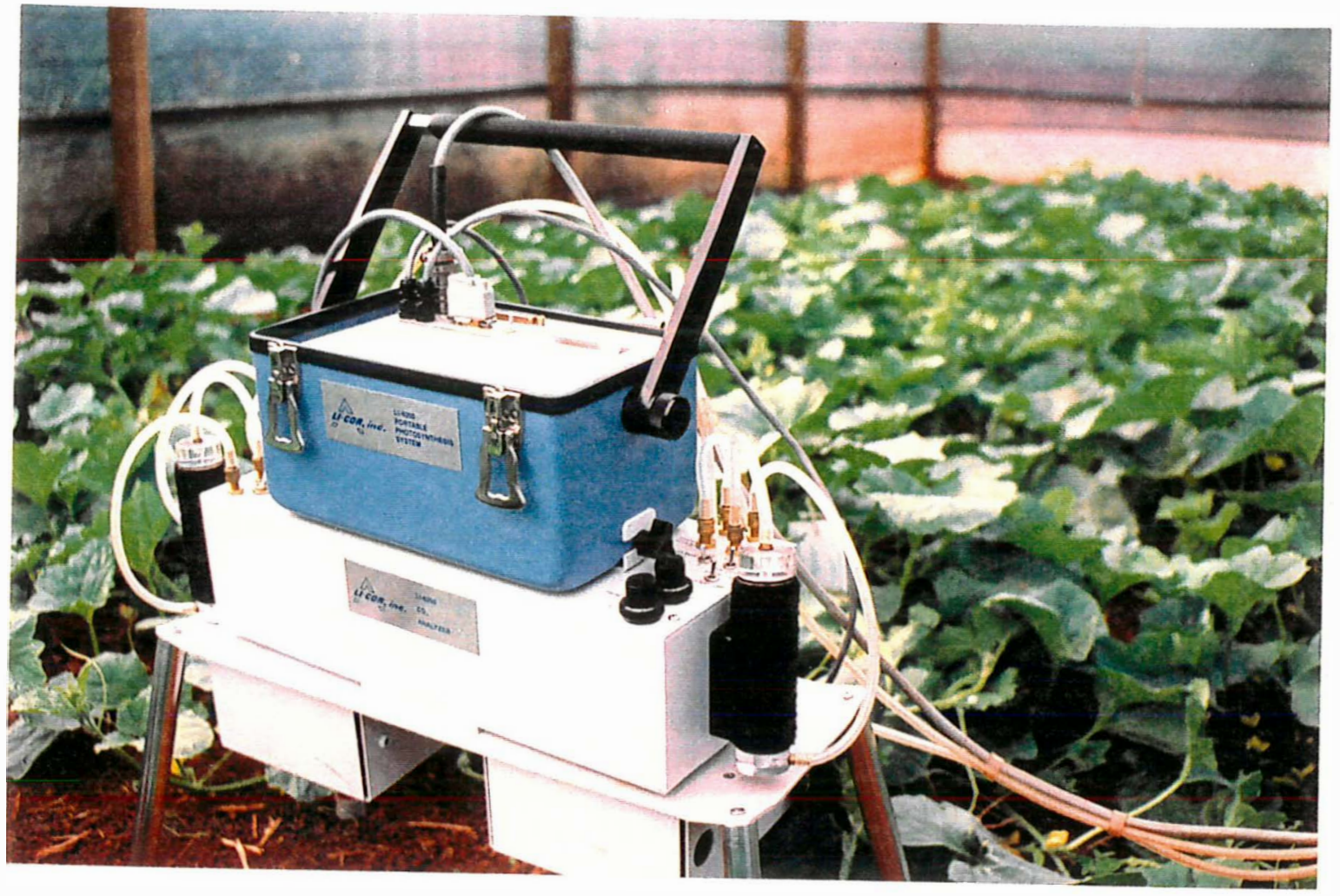

Figura 2 - Aparelho da Licor 6200, IRGA, usado para medir fotossíntese.

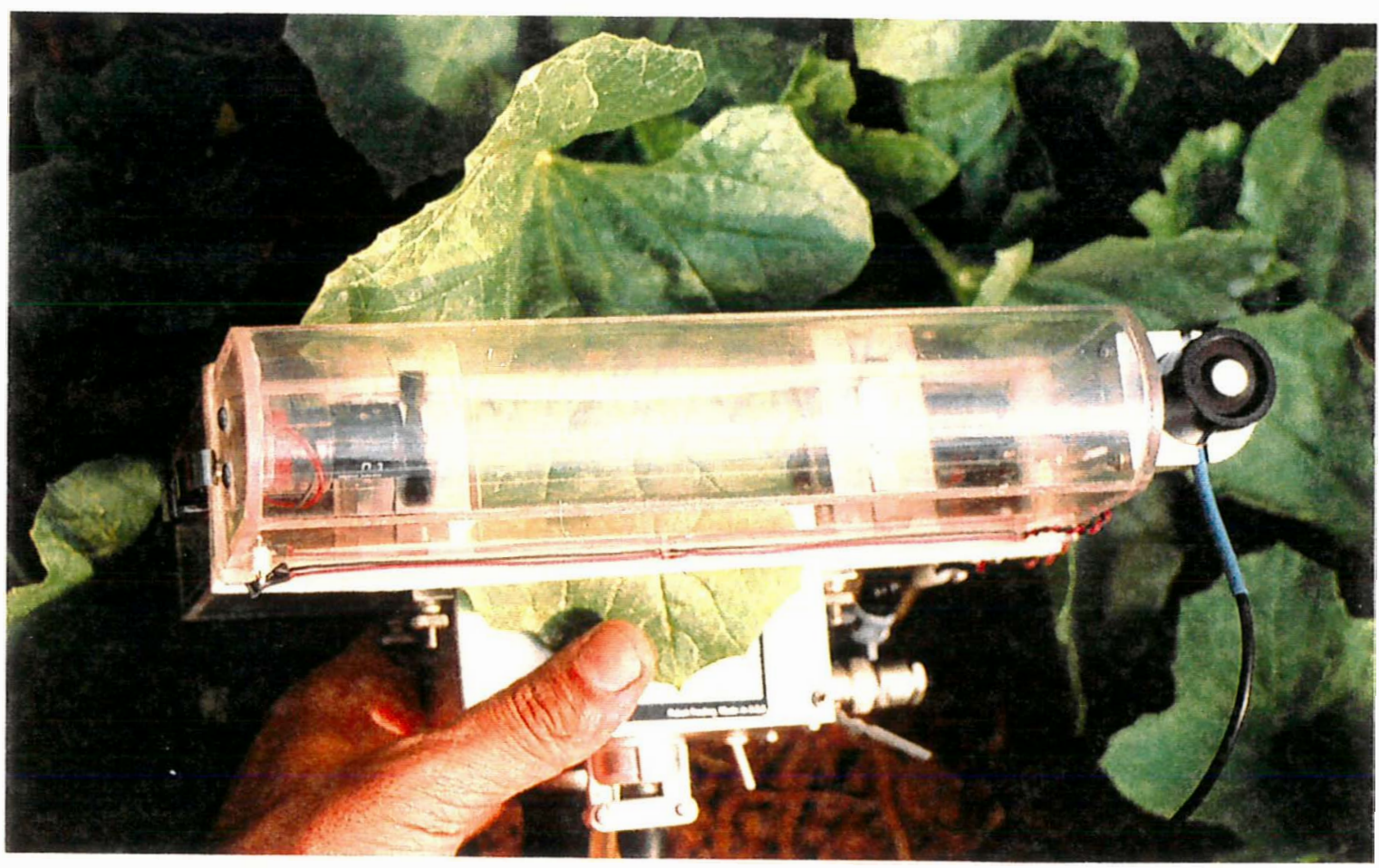

Figura 3 - Detalhe da medida de fotossíntese. 


\section{2- Aplicação de dióxido de carbono via água de irrigação}

\subsection{1- Localização do experimento}

As coordenadas geográficas do local são $22^{\circ} 42^{\prime} 30^{\prime \prime}$ de latitude sul, $47^{\circ} 38^{\prime}$ de longitude oeste e altitude de $580 \mathrm{~m}$. O clima da região, segundo classificação de Köpper, é do tipo mesotérmico CWA, subtropical úmido com estiagem no inverno. A precipitação pluvial média anual é de $1250 \mathrm{~mm}$, sendo que a maior parte ocorre no verão (novembro a fevereiro). A temperatura média do ar é de $20,8^{\circ} \mathrm{C}$, com mínima da ordem de $10^{\circ} \mathrm{C}$ em julho e máxima em torno de $30^{\circ} \mathrm{C}$ em janeiro e umidade relativa do ar média de aproximadamente 69\% (Ometto, 1989).

Sparovek et al. (1993) classificaram o solo onde foi instalado o experimento como sendo Terra Roxa Estruturada eutrófica, identificado pela classificação americana como Kandiudalfic Eutrudox, cujo material de origem é constituído por rochas básicas.

Para caracterização química do solo, realizou-se pelo Laboratório de Nutrição Mineral de Plantas da ESALQ, análise química do solo da camada $0-0,20 \mathrm{~m}$ para quantificação da adubação a ser utilizada. $O$ fósforo foi aplicado em sulcos contínuos por ocasião do plantio; o potássio e o nitrogênio foram aplicados três vezes por semana via água de irrigação. Os resultados das análises dos solos são mostrados na (Tabela 2).

Tabela 2. Análises químicas dos solos utilizados nos experimentos.

\begin{tabular}{|c|c|c|c|c|c|c|c|c|c|c|}
\hline Experimento & $\mathrm{pH}$ & M.O. & $P$ & K & $\mathrm{Ca}$ & $\mathrm{Mg}$ & $\mathrm{H}+\mathrm{Al}$ & $S$ & $\mathrm{~T}$ & V \\
\hline & $\mathrm{CaCl}$ & g. $\mathrm{kg}^{-1}$ & $\mathrm{mg} \cdot \mathrm{kg}^{-1}$ & & & .....mr & ${ }^{10 l_{c}} \cdot \mathrm{L}^{-1}$ & & & $\%$ \\
\hline A. proteg. 1 & 5,00 & 18,0 & 3,5 & 1,6 & 14,4 & 4,9 & 34,3 & 21 & 55 & 37,9 \\
\hline A. proteg. 2 & 4,85 & 20,0 & 3,6 & 1,0 & 20,6 & 3,7 & 44,6 & 15 & 60 & 25,5 \\
\hline Campo & 5,15 & 21,5 & 5,4 & 3,0 & 27,1 & 10,9 & 40,1 & 41 & 81 & 50,6 \\
\hline
\end{tabular}


Com relação à caracterização física do solo, na camada de $0-0,20 \mathrm{~m}$, retirou-se amostras indeformadas para determinação de densidade, granulometria (Tabela 3 ) e curva de retenção de água do solo (Figura 4), realizadas no Laboratório de Física de Solos do Departamento de Engenharia Rural, utilizando-se o método de membrana de pressão, descrito por Richards (1947).

Tabela 3. Características físicas do solo usado no experimento de campo, na camada 0 a $0,20 \mathrm{~m}$.

\begin{tabular}{ccccc}
\hline $\begin{array}{c}\text { Densidade } \\
\mathrm{kg} \cdot \mathrm{m}^{-3}\end{array}$ & Granulometria (\%) & Classe \\
& Areia & Silte & Argila & Textura \\
\hline 1500 & $18,9 \ldots \ldots \ldots \ldots \ldots \ldots \ldots \ldots \ldots \ldots \ldots \ldots \ldots \ldots$ & & argila \\
\hline
\end{tabular}

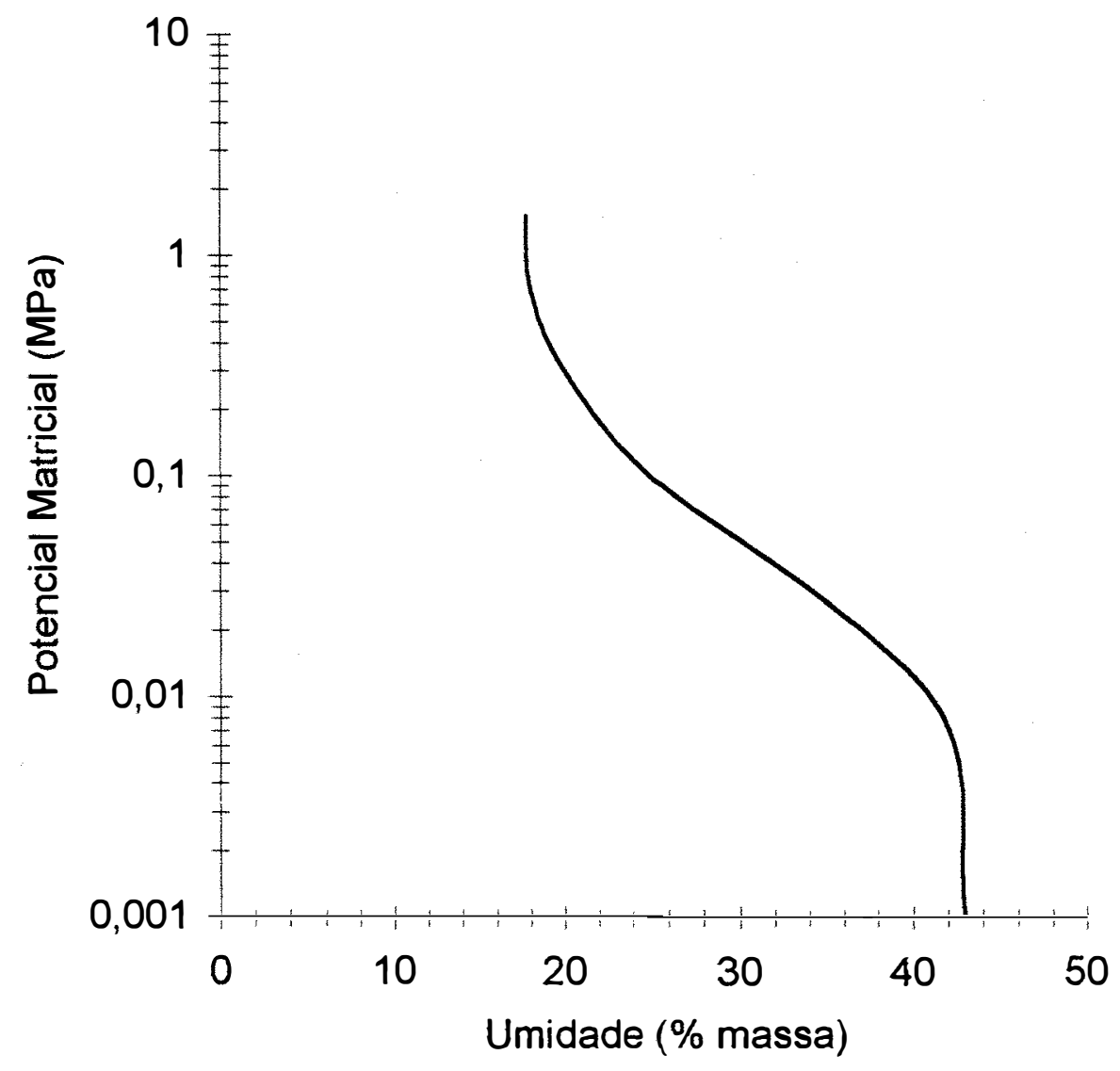

Figura 4 - Curva de retenção da água no solo do experimento de campo. 


\subsection{2- Plantio e tratos culturais}

Utilizou-se o cultivar de melão Valenciano Amarelo. As mudas foram preparadas em bandejas de isopor preenchidas com substrato de nome comercial Eucatex Plantimax ${ }^{2}$. As sementes foram tratadas com Rhodiauram - 70. Colocou-se duas sementes por célula, em semeadura realizada em 18/02/96, para o experimento de campo e em 12/03/97 para o experimento em ambiente protegido. Três dias após a germinação fez-se o desbaste, deixando uma planta por célula. A formação de mudas foi conduzida em casa de vegetação localizada no Setor de Horticultura da ESALQ. Durante a formação das mudas as irrigações foram realizadas quatro vezes ao dia, por períodos de dez minutos, através de nebulizadores, com acionamento automático, visando satisfazer as necessidades hídricas da cultura e a refrigeração do viveiro.

Para o plantio no local do experimento em condições de campo o solo foi arado e gradeado. Incorporou-se através de gradagem 2,4 t.ha ${ }^{-1}$ de calcário no solo 45 dias antes do transplantio. A adubação com fósforo (150 kg.ha $\left.{ }^{-1}\right)$ na forma de superfosfato simples e aplicação de esterco de curral curtido $\left(5\right.$ t.ha $\left.^{-1}\right)$ foram realizadas em sulcos uma semana antes do transplantio.

Os solos dos locais com ambientes protegidos foram arados. Incorporou-se 3,5 t.ha ${ }^{-1}$ de calcário no solo 35 dias antes do transplantio. A adubação com fósforo (180 $\left.\mathrm{kg} \cdot \mathrm{ha}^{-1}\right)$ na forma de superfosfato simples e aplicação de esterco de curral $\left(5 \mathrm{t}^{-\mathrm{ha}^{-1}}\right)$ foram realizadas em sulcos uma semana antes do transplantio.

$\mathrm{O}$ transplantio foi realizado quando as plantas emitiram a terceira folha, 20 dias após a semeadura. $O$ espaçamento foi de dois metros entre linhas e 0,6 metro entre plantas na linha, com uma planta por cova. A cultura foi conduzida de forma natural, sem desbastes e sem desbrotas no experimento em condições de campo enquanto que nos ambientes protegidos eliminaram-se ramos laterais até a $5^{\text {a }}$ folha. Nos ambientes protegidos a polinização foi realizada artificialmente, sempre pela manhã (Souza, 1993).

\footnotetext{
${ }^{2}$ A citação durante o texto de marcas ou produtos comerciais não configura recomendação do autor.
} 
As adubações de cobertura foram feitas três vezes por semana, aplicando-se nitrogênio e potássio via água de irrigação, utilizando-se um tanque de fertilizantes. A dose total de nitrogênio foi de $130 \mathrm{~kg} \cdot \mathrm{ha}^{-1}$ e a de potássio foi $180 \mathrm{~kg} \cdot \mathrm{ha}^{-1}$, na forma de nitrato de potássio. Após o transplantio iniciou-se a fertirrigação que se estendeu por 60 dias, uma semana antes da primeira colheita.

Utilizou-se o método de pressão diferencial para injetar fertilizantes na água de irrigação, empregando-se um tanque de derivação de fluxo de concentração variável, com capacidade de 50 litros. $O$ equipamento foi calibrado para um tempo de injeção de 30 minutos e concentração final de $2 \%$. Para calibrar o equipamento adotou-se o método proposto pela FAO e simplificado por Shani (1981), que consiste em passar pelo tanque de fertilizantes um volume de água igual a quatro vezes o seu volume.

O controle fitossanitário foi realizado de acordo com as recomendações técnicas, com o cuidado de não se pulverizar o experimento no período da manhã, para não causar morte das abelhas polinizadoras. Procurou-se prevenir principalmente o míldio (Pseudoperonospora cubensis), micosferela (Mycosphaerella melonis), oídio (Erysiphe chicoracearum), antracnose (Colletotrichum gloeosporioides), pulgão (Aphis gosypii), e vaquinha (Diabrota speciosa) com pulverizações com Benomyl, Macozeb, Benlate e Mevinphos, Cerconil e Decis. Para evitar o ataque da broca das cucurbitáceas ensacaramse os frutos.

\subsection{3- Irrigação e aplicação de dióxido de carbono}

O experimento foi irrigado pelo método de irrigação localizada, utilizando-se tubo gotejador Rain-Tape TPC, fabricado pela Rain-Bird, constituído de polietileno linear de baixa densidade com espessura de parede de 225 microns. Os gotejadores eram autocompensáveis, do tipo labirinto, fluxo turbulento e espaçamentos entre emissores de $0,30 \mathrm{~m}$ e vazão de $1 \mathrm{~L} \cdot \mathrm{h}^{-1} \cdot \mathrm{m}^{-1}$ para pressão de serviço de $49 \mathrm{kPa}$, cujas características hidráulicas foram estudas por Vieira (1996). As linha laterais, com comprimento de seis metros foram dispostas próximas às fileiras de plantas, espaçadas de dois metros. 
O sistema de irrigação foi composto por um conjunto moto-bomba, com cabeçal de controle formado por um filtro de areia e um filtro de tela, próximo ao local de bombeamento. Junto ao experimento, instalou-se um tanque de derivação de fluxo para injeção de nutrientes na água de irrigação, além de dois filtros de tela de 200 mesh, sendo um antes e outro depois do tanque, hidrômetro, válvula de controle de pressão e registros para controle de irrigação.

As irrigações foram feitas diariamente, com início às 11,00 horas da manhã, calculadas com base no coeficiente de cultivo $(\mathrm{Kc})$ determinado por Doorenbos \& Pruit (1976), e fator de correção devido a cobertura do solo (Kr) determinado pela relação das dimensões dos ramos no sentido transversal às linhas de plantio e espaçamento entre linhas, utilizados por Hemandez (1995). E evaporação do tanque classe A.

O valor da evapotranspiração, utilizada no cálculo do tempo de irrigação, foi obtido por:

$$
\mathrm{ETc}=\mathrm{Ev} \cdot \mathrm{Kc} \cdot \mathrm{Kp} \cdot \mathrm{Kr}
$$

em que:

ETc $=$ evapotranspiração cultural, $m m \cdot d i a^{-1}$;

$\mathrm{Ev}=$ evaporação do tanque classe $\mathrm{A}, \mathrm{mm} \cdot \mathrm{dia}^{-1}$;

$\mathrm{Kc}=$ coeficiente de cultura (adimensional);

$\mathrm{Kp}=$ coeficiente de instalação do tanque classe $\mathrm{A}$, valof-de 0,75 (adimensional);

$\mathrm{Kr}=$ fator de correção devido a cobertura do solo (adimensional).

O tempo de irrigação foi calculado pela expressão:

$$
\mathrm{TI}=\mathrm{E} \cdot \mathrm{e} \cdot \mathrm{ETc} \cdot \mathrm{q}^{-1} \varepsilon^{-1}
$$

em que:

$\mathrm{TI}=$ tempo de irrigação, horas;

$\mathrm{E}=$ espaçamento entre linhas, $\mathrm{m}$;

$\mathrm{e}=$ espaçamento entre plantas, $\mathrm{m}$;

$q=$ vazão do emissor, $L \cdot h^{-1}$;

$\varepsilon=$ eficiência de irrigação, adotou-seovator de 0,9 . 
Os coeficientes de cultura $(\mathrm{kc})$ foram:

fase inicial - até 10 dias após o transplantio, 0,5;

desenvolvimento vegetativo $-11^{\circ}$ dia ao início do florescimento, 1,1 ;

florescimento e frutificação - início do florescimento à primeira colheita, 1,2;

colheita - após a primeira colheita, 0,7

E os fatores de correção devido a cobertura do solo foram:

fase inicial: 0,30 ;

desenvolvimento vegetativo: 0,60 ;

florescimento e frutificação: 1 ;

colheita: 1 .

$\mathrm{O}$ sistema de aplicação de $\mathrm{CO}_{2}$ foi composto de um conteiner (cilindro de dióxido de carbono de alta pressão) para armazenar dióxido de carbono, equipado com uma válvula para quantificar a dose de dióxido de carbono a ser liberada do cilindro, manômetro e um injetor para introduzir o $\mathrm{CO}_{2}$ na água de irrigação (Figuras 5, 6 e 7).

A aplicação de dióxido de carbono foi iniciada no dia seguinte ao transplantio, estendendo-se até a primeira colheita. $\mathrm{O}$ tempo de cada aplicação foi de 30 minutos, com início às 11:00 horas e a dose aplicada foi de $50 \mathrm{~kg} \mathrm{ha}^{-1}$ do transplantio à colheita.

No ambiente protegido, com aplicação de dióxido de carbono, instalou-se uma estação meteorológica automática, com sensores de temperatura e umidade relativa do ar, radiação solar global e radiação líquida, densidade de fluxo de calor no solo e um tanque classe A modificado, com dimensões de $0,6 \mathrm{~m}$ de diâmetro e $0,25 \mathrm{~m}$ de altura. Medeiros et al. (1997) determinou uma equação de regressão para correlacionar a evaporação do tanque classe A com a evaporação do tanque modificado, instalado em estufa:

$$
\mathrm{Y}=1,14 \mathrm{X}+0,03\left(\mathrm{R}^{2}=0,935\right)
$$

em que:

$\mathrm{Y}$ - evaporação do tanque modificado, dentro da estufa, $\mathrm{mm} \cdot \operatorname{dia}^{-1}$;

$\mathrm{X}$ - evaporação do tanque classe $\mathrm{A}$, fora da estufa, $\mathrm{mm} \cdot \mathrm{dia}^{-1}$. 


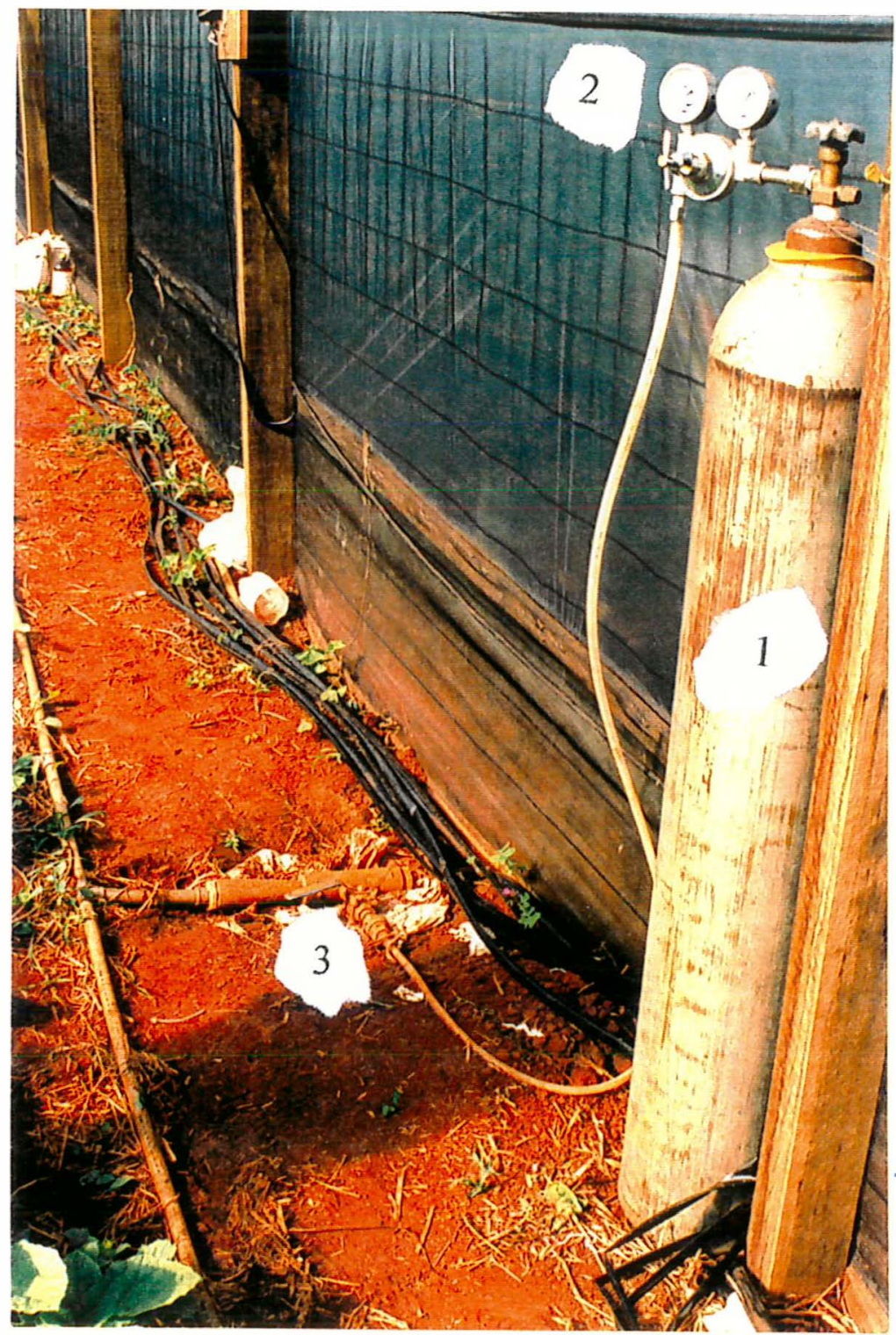

Figura 5 - Dispositivo usado para injetar $\mathrm{CO}_{2}$ na água de irrigação.

1. Cilindro de gás carbônico; 2. manômetro e válvula de controle da taxa de injeção de $\mathrm{CO}_{2} ; 3$. injetor de $\mathrm{CO}_{2}$. 


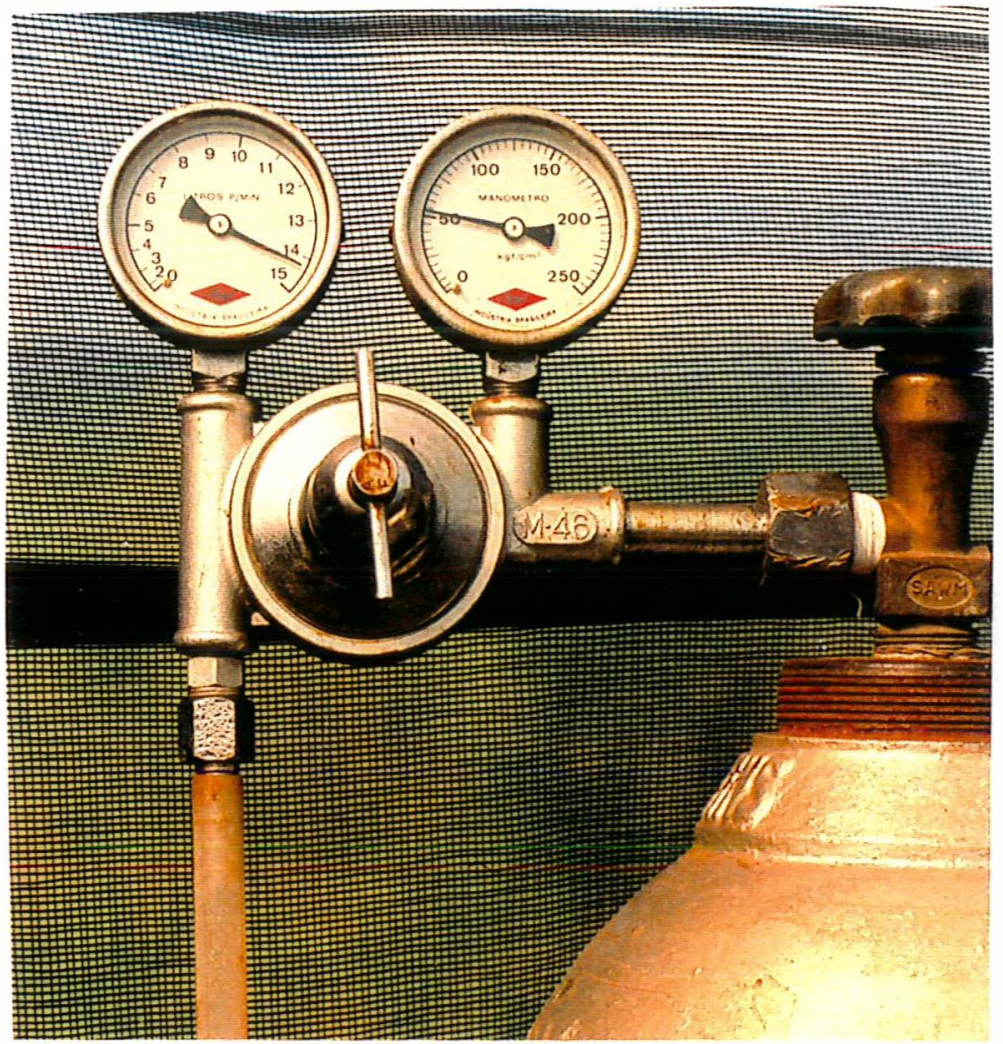

Figura 6 - Detalhe do sistema de controle da taxa de injeção de $\mathrm{CO}_{2}$.

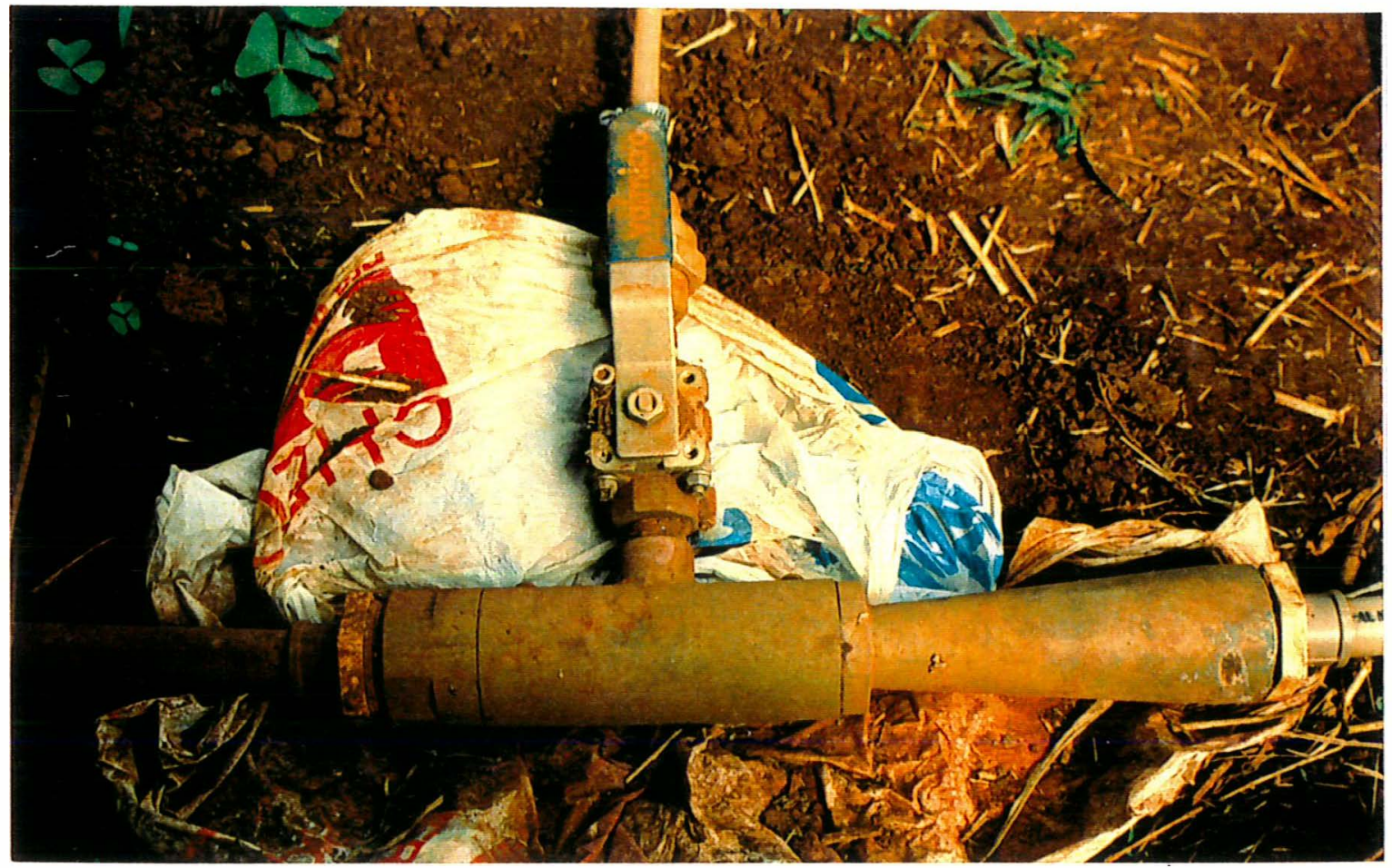

Figura 7 - Detalhe do injetor de $\mathrm{CO}_{2}$. 


\section{3- Tratamentos e análise estatística}

\subsection{1- Aplicação de dióxido de carbono em condições de campo}

A aplicação de dióxido de carbono via água de irrigação foi realizada diariamente, três vezes por semana e sem aplicação de $\mathrm{CO}_{2}$ (testemunha) em três maneiras de condução da cultura: a primeira, com proteção lateral; a segunda, solo coberto com plástico (mulch) e a terceira, solo sem nenhuma proteção, em um delineamento estatístico em blocos ao acaso, com quatro repetições, totalizando 36 parcelas experimentais (Figura 8). Cada unidade experimental foi constituída por uma linha de plantas com seis metros de comprimento, espaçadas de dois metros. Como bordadura considerou-se meio metro no início e no final de cada parcela. Cada tratamento ficou formado por dez plantas úteis.

Os tratamentos foram:

$\mathrm{T}_{1}$ - Proteção lateral com aplicação diária de $\mathrm{CO}_{2}$;

$\mathrm{T}_{2}$ - Proteção lateral com aplicação de $\mathrm{CO}_{2}$ três vezes por semana;

$\mathrm{T}_{3}$ - Proteção lateral sem aplicação de $\mathrm{CO}_{2}$;

$\mathrm{T}_{4}$ - Solo coberto com plástico com aplicação diária de $\mathrm{CO}_{2}$;

$\mathrm{T}_{5}$ - Solo coberto com plástico com aplicação de $\mathrm{CO}_{2}$ três vezes por semana;

$\mathrm{T}_{6}$ - Solo coberto com plástico sem aplicação de $\mathrm{CO}_{2}$;

$\mathrm{T}_{7}$ - Solo nu com aplicação diária de $\mathrm{CO}_{2}$;

$\mathrm{T}_{8}$ - Solo nu com aplicação de $\mathrm{CO}_{2}$ três vezes por semana;

$\mathrm{T}_{9}$ - Solo nu sem aplicação de $\mathrm{CO}_{2}$.

A proteção lateral consistiu-se de plástico transparente colocado perpendicular à superficie do solo, cercando cada parcela em toda sua volta, com seis metros de comprimento, dois metros de largura e altura de aproximadamente $1,30 \mathrm{~m}$, sem cobertura em sua parte superior, ou seja uma casa de vegetação com laterais de plástico sem a cobertura. A finalidade da proteção lateral foi minimizar o arraste do $\mathrm{CO}_{2}$ pelo vento. 
Nos tratamentos com solo coberto utilizou-se plástico preto, cobrindo uma faixa de solo de aproximadamente $1,2 \mathrm{~m}$ de largura.

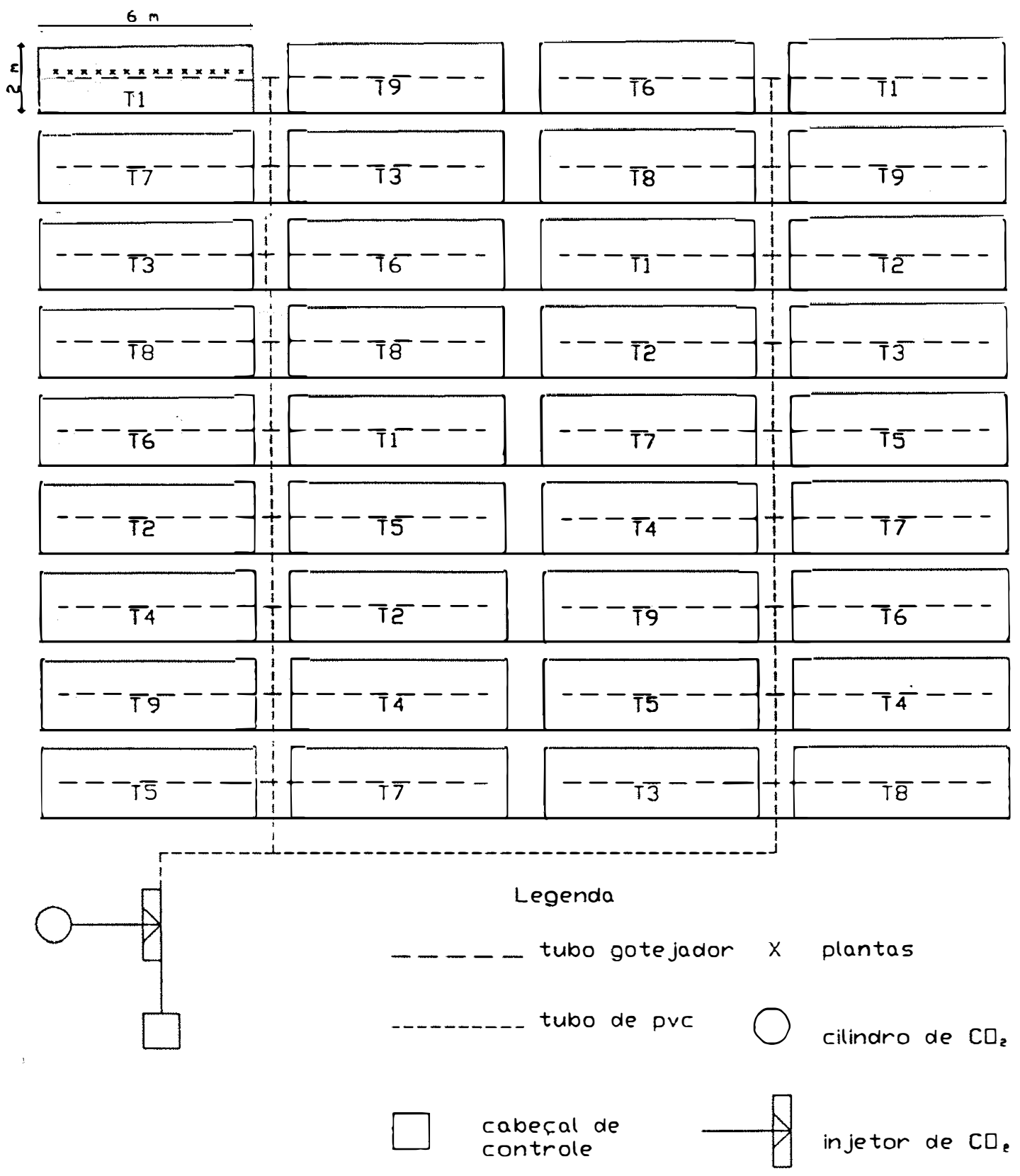

Figura 8 - Esquema da disposição dos tratamentos no campo. 


\subsection{2- Aplicação de dióxido de carbono em ambiente protegido}

Utilizou-se dois ambientes protegidos, com $20 \mathrm{~m}$ de comprimento e oito metros de largura cada, sendo um com aplicação de $\mathrm{CO}_{2}$ realizada às 11:00 horas e outro sem aplicação de $\mathrm{CO}_{2}$. Em cada ambientes protegidos instalaram-se dez linhas de plantas, sendo que duas de cada lado constituíram-se na bordadura e a parcela útil foi formada pelas seis linhas centrais. Em cada fileira de plantas úteis selecionou-se uma planta para as medições de fotossintese. A dose de $\mathrm{CO}_{2}$ foi de $50 \mathrm{~kg}$.ha ${ }^{-1}$ do transplantio à colheita.

A produção, as características químicas e a fotossíntese foram analisadas estatisticamente através de análise de variância pelo teste $\mathrm{F}$ e as médias comparadas pelo teste de Tukey a $5 \%$ de probabilidade.

\section{4- Parâmetros avaliados nos experimentos de campo e ambiente protegido}

\subsection{1- Produção de frutos}

Os frutos foram pesados individualmente e estimada a produtividade em $\mathrm{kg} \cdot \mathrm{ha}^{-1}$ obtida em cada tratamento.

\subsection{2- Peso médio dos frutos}

$O$ valor apresentado corresponde ao valor médio de cada tratamento calculado pela somatória dos valores obtidos em cada colheita dividido pelo número total de frutos.

\subsection{3- Teor de sólidos solúveis, acidez total e pH}

Na colheita foram amostrados quatro frutos por parcela para avaliação do teor de sólidos solúveis, acidez total e $\mathrm{pH}$. As analises foram realizadas no dia da colheita e, 
armazenamento aos dez, vinte e trinta dias após a colheita, conservado em sacos de ráfia armazenado em ambiente coberto. $\mathrm{O}$ teor de sólidos solúveis foi medido pelo método do refratômetro de mesa, e o pH utilizando-se um peagâmetro. A determinação da acidez foi feita pela titulação de suco com solução de $\mathrm{NaOH} 0,01 \mathrm{~N}$, segundo método descrito pelo Instituto Adolfo Lutz (1985). As análises químicas dos frutos foram realizadas na Seção de Fruticultura do Centro de Energia Nuclear na Agricultura - CENA. Calculou-se, também, a relação teor de sólidos solúveis e acidez total, que é usada para avaliar tanto o estado de maturação, quanto a palatabilidade dos frutos. Se essa relação estiver acima de 24 e a acidez total estiver abaixo de $0,5 \%$, o fruto terá bom sabor e boa coloração (Salomão et al., 1988).

\subsection{4- Análise química de folhas}

Em cada parcela, após medir a fotossintese, coletou-se, na época da frutificação, amostras de folhas para análise química. As folhas coletadas foram as maduras, localizadas imediatamente após os frutos no sentido do ápice. No experimento em condições de campo coletou-se uma amostra por parcela e no experimento em ambiente protegido uma amostra composta em cada ambiente protegido. As análise de folhas foram realizadas no Laboratório de Nutrição Mineral de Plantas da ESALQ.

\subsection{5- Taxa de assimilação de $\mathrm{CO}_{2}$ pelas plantas}

A taxa de assimilação de $\mathrm{CO}_{2}$, determinada apenas no experimento em ambiente protegido, foi medida às $10,11,12$ e às 14 horas no período entre 11 e 19 de maio de 1997, na época do florescimento e frutificação. Selecionou-se, através de sorteio, uma planta de cada parcela e desta planta escolheu-se uma folha madura imediatamente após o primeiro fruto. Para medir a taxa de assimilação de $\mathrm{CO}_{2}$ utilizou-se um analisador portátil para fotossíntese, por infravermelho, IRGA LI 6200 da Licor, mostrado nas Figuras 2 e 3. As medidas foram sempre efetuadas na mesma folha da planta selecionada. 


\subsection{6- Eficiência do uso de água}

A determinação da eficiência do uso de água, realizada segundo metodologia proposta por Doorenbos \& Kassan (1988) para produção final, foi feita através da relação entre o peso total de frutos $\left(\mathrm{kg} \cdot \mathrm{ha}^{-1}\right)$ e consumo de água $\left(\mathrm{m}^{3} \cdot \mathrm{ha}^{-1}\right)$ durante o ciclo da cultura.

\subsection{7- Índice de aproveitamento comercial da produção}

Calculou-se o índice de aproveitamento comercial da produção dividindo-se a produção comercial pela produção total. 


\section{4- RESULTADOS E DISCUSSÃO}

\section{1- Taxa de assimilaçảo de $\mathrm{CO}_{2} \mathrm{em}$ funçảo da concentração de dióxido de carbono}

A taxa de assimilação e a concentração interna de dióxido de carbono foram medidas considerando uma variação de $5 \mu \mathrm{molCO}_{2} \cdot \mathrm{mol}^{-1}$ na concentração de $\mathrm{CO}_{2}$ na câmara de fotossíntese, com medidas sucessivas até que a taxa de assimilação de $\mathrm{CO}_{2}$ atingisse valores próximos a zero, ou seja ponto de compensação de $\mathrm{CO}_{2}$. Os resultados são mostrados na Figura 9.

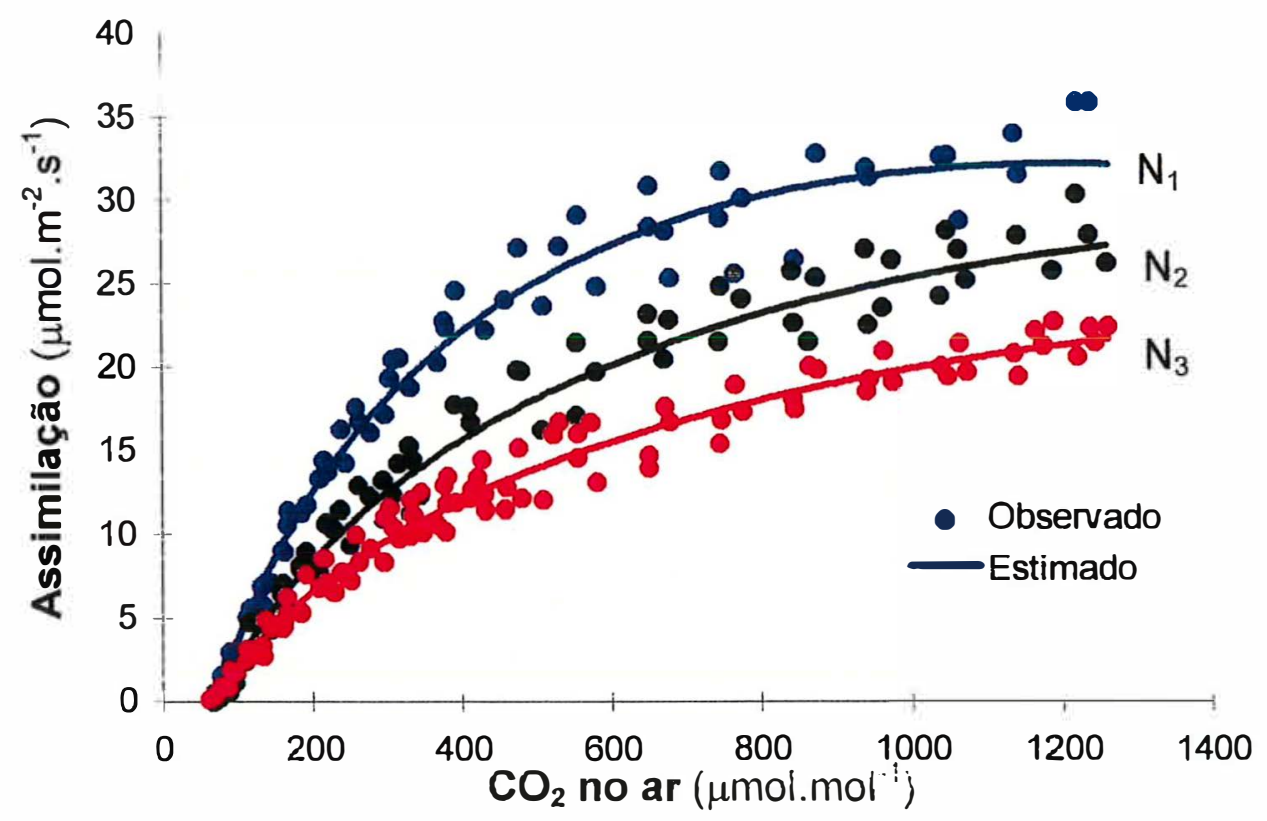

Figura $\hat{9}$ - Taxa de assimilaçào de $\mathrm{CO}_{2}$ em meioeiro, em funçào da concentraçào de $\mathrm{CO}_{2}$ para vaiores de PAR de $850\left(\hat{N} N_{1}\right), 550\left(\mathrm{~N}_{2}\right)$ e $300\left(\mathrm{~N}_{3}\right) \mu$ moi.m. $\mathrm{m}^{-2} \cdot \mathrm{s}^{-1}$, medida em laboratório entre 9:00 e 16:00h e temperatura variando entre 26 e $28^{\circ} \mathrm{C}$ 
Para cada valor de PAR ajustou-se, pela análise de regressão, uma equação descrevendo a variação da taxa de assimilação de $\mathrm{CO}_{2}$ em função da concentração de dióxido de carbono. As equações ajustadas seguiram o modelo raiz quadrada, para os três valores de PAR, 850,550 e $300 \mu \mathrm{mol} \cdot \mathrm{m}^{-2} . \mathrm{s}^{-1}$, respectivamente:

$\mathrm{Y}=-23,3369+3,1966 \mathrm{X}^{0,5}-4,6074 \cdot 10^{-2} \mathrm{X}\left(\mathrm{R}^{2}=0,9810\right)$

$\mathrm{Y}=-15,1131+1,9799 \mathrm{X}^{0,5}-2,2008 \cdot 10^{-2} \mathrm{X}\left(\mathrm{R}^{2}=0,9709\right)$

$\mathrm{Y}=-10,2147+1,3927 \mathrm{X}^{0,5}-1,3939 \cdot 10^{-2} \mathrm{X}\left(\mathrm{R}^{2}=0,9788\right)$

em que:

$\mathrm{Y}$ - taxa de assimilação de $\mathrm{CO}_{2}, \mu \mathrm{mol} \cdot \mathrm{m}^{-2} \cdot \mathrm{s}^{-1}$;

$\mathrm{X}$ - concentração de $\mathrm{CO}_{2}, \mu \mathrm{molCO}_{2} \cdot \mathrm{mol}^{-1}$.

Observa-se, pela Figura 9, que, para baixa concentração de dióxido de carbono, pequenos incrementos correspondem a maiores variações na taxa de assimilação de $\mathrm{CO}_{2}$. A magnitude da variação da taxa de assimilação de $\mathrm{CO}_{2}$ diminui até aproximar-se de zero. Para a concentração de dióxido de carbono de $365 \mu \mathrm{molCO}_{2} \cdot \mathrm{mol}^{-1}$, que é aproximadamente a concentração encontrada na atmosfera, a taxa de assimilação de $\mathrm{CO}_{2}$ determinada pelas equações 4,5 e 6 são: 20,9; 14,7 e 11,3 $\mu \mathrm{mol} \cdot \mathrm{m}^{-2} \cdot \mathrm{s}^{-1}$, respectivamente. Aumentando $100 \mu \mathrm{molCO}_{2} \cdot \mathrm{mol}^{-1}$ na concentração de dióxido de carbono, esses valores tornam-se: 24,$2 ; 17,4$ e 13,3 $\mu$ mol.m ${ }^{-2} . s^{-1}$. Aumento este, de 15,79\%, 18,37\%, 17,70\%, para os valores de concentração de $\mathrm{CO}_{2}$ iguais a 850,550 e $300 \mu \mathrm{molCO}_{2} \cdot \mathrm{mol}^{-1}$, respectivamente. A taxa de assimilação de $\mathrm{CO}_{2}$ tende a cessar seu aumento quando a concentração de dióxido de carbono atinge o valor de $1000 \mu \mathrm{molCO}_{2} \cdot \mathrm{mol}^{-1}$ para PAR de $850 \mu \mathrm{mol} \cdot \mathrm{m}^{-2} \cdot \mathrm{s}^{-1}$. Para valor do PAR de 550 e $300 \mu \mathrm{mol} \cdot \mathrm{m}^{-2} \cdot \mathrm{s}^{-1}$ a taxa de assimilação de $\mathrm{CO}_{2}$ aumentou, embora com incrementos menores, para valores concentração de $\mathrm{CO}_{2}$ acima de $1000 \mu \mathrm{molCO}_{2} \cdot \mathrm{mol}^{-1}$.

A temperatura ótima para o desenvolvimento das plantas aumenta em ambiente com maior concentração de dióxido de carbono, podendo atingir valores próximo de $40^{\circ} \mathrm{C}$. Temperaturas acima de $40^{\circ} \mathrm{C}$ podem causar redução na taxa fotossintética (Jurik et 
al., 1984). Maior concentração de dióxido de carbono, implica em aumento da taxa de assimilação de $\mathrm{CO}_{2}$, com acréscimo na produção de fotoassimilados, que podem ser utilizados para produção de massa vegetal e expansão da área foliar, durante o desenvolvimento vegetativo e, em maior parte para formação de frutos, na fase de frutificação.

\section{2- Taxa de assimilação de $\mathrm{CO}_{2} \mathrm{em}$ função da radiação fotossinteticamente ativa}

A variação da taxa de assimilação de $\mathrm{CO}_{2}$ em função do PAR (Figura 10), foi descrita pela equação raiz quadrada seguinte:

$\mathrm{Y}=-4,5221+0,8242 \cdot \mathrm{Z}^{0,5}-6,6852 \cdot 10^{-3} \cdot \mathrm{Z}\left(\mathrm{R}^{2}=0,9535\right)$

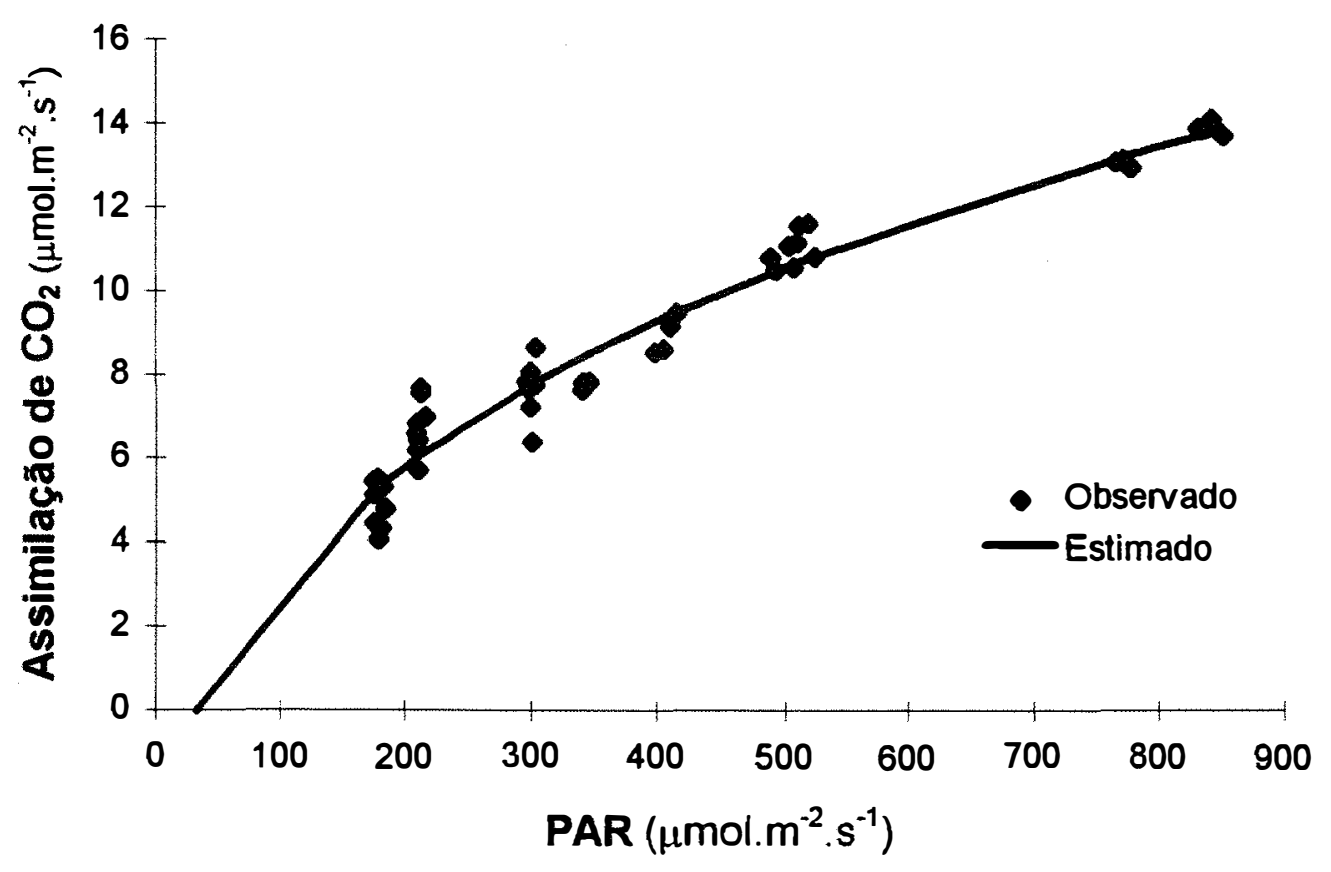

Figura 10 - Taxa de assimilação de $\mathrm{CO}_{2}$ em meloeiro, em função do PAR medida em concentração de $\mathrm{CO}_{2}$ ambiente de laboratório, entre 9:00 e 16:00h e temperatura compreendida entre 26 e $28^{\circ} \mathrm{C}$. 
em que:

$\mathrm{Y}$ - taxa de assimilação, $\mu \mathrm{mol} \cdot \mathrm{m}^{-2} \cdot \mathrm{s}^{-1}$;

$\mathrm{Z}$ - radiação fotossintecamente ativa, $\mu \mathrm{mol} \cdot \mathrm{m}^{-2} \cdot \mathrm{s}^{-1}$.

Embora, pela análise de variância, os parâmetros da equação tenham sido significativos a $1 \%$ de probabilidade, o ponto de saturação lumínica não foi determinado com nitidez. Verifica-se (Figura 10) que a curva não atingiu a forma de uma assíndota, apresentando tendência de crescimento na taxa de assimilação. Este fato pode ser atribuído à limitações do sistema de iluminação, que não permitiu maior amplitude do limite superior do PAR.

Através da equação ajustada da taxa de assimilação de $\mathrm{CO}_{2}$ versus radiação pôdese estimar o ponto de compensação luminoso, $33,1 \mu \mathrm{mol} \cdot \mathrm{m}^{-2} \cdot \mathrm{s}^{-1}$, valor do PAR para taxa de assimilação igual a zero, superior ao encontrado por Prado et al. (1994) igual a 16,0 $\mu \mathrm{mol} \cdot \mathrm{m}^{-2} \cdot \mathrm{s}^{-1}$, em Copaifera langsdorffi, planta de cerrado, com seis meses de idade, mas inferior ao valor $\left(59,0 \mu \mathrm{mol} \cdot \mathrm{m}^{-2} \cdot \mathrm{s}^{-1}\right)$ obtido por Rocha \& Moraes (1997) em plantas de seis meses de idade de Stryphnodendron adstringens (Mat.) Coville nativa em cerrado.

\section{3- Aplicação de dióxido de carbono via água de irrigação em meloeiro em condições de campo}

\subsection{1- Desenvolvimento da cultura}

O ciclo fenológico da cultura foi de 105 dias. Foram realizadas duas colheitas: 85 e 105 dias após o plantio. Souza (1993) em Botucatu e Hernandez (1995), Ilha Solteira, regiões edafo-climáticas distintas em São Paulo, observaram um ciclo da cultura de 109 e 108 dias, respectivamente, adotando o sistema de formação de mudas e transplantio para o campo. A utilização do sistema de formação de mudas provoca atraso no ciclo da cultura, entretanto, o manejo da cultura, no periodo em que as mudas estão no viveiro é 
facilitado, pois não se faz capinas e pulverizações, reduzindo-se os custos de produção. Todavia, Belfort et al. (1986)m Presidente Wenceslau, SP, e Buzetti et al. (1993), em Ilha Solteira, SP, obtiveram ciclos de 75 e 85 dias. Na região Nordeste do Brasil a primeira colheita pode ser realizada 60 dias após a semeadura, com o ciclo da cultura estendendo-se ao redor de 100 dias (Dusi, 1992).

A aplicação de $\mathrm{CO}_{2}$ via água de irrigação não modificou o ciclo da cultura, discordando de resultados encontrados na literatura para outras culturas. Vessey et al. (1990) e Stuhlfauth \& Fock (1990) observaram que a aplicação de $\mathrm{CO}_{2}$ no ambiente das culturas reduziu o ciclo da cultura. Ghannoum et al. (1997) observaram antecipação de cinco dias no florescimento e uma semana na colheita em cultivo em condições de casa de vegetação, em ambiente enriquecido $\operatorname{com} \mathrm{CO}_{2}$.

\subsection{2- Aspectos produtivos}

Verificou-se, pela análise de variância, que as diferenças na produção total, produção comercial, número e peso médio de frutos comerciais foram significativos à $1 \%$ de probabilidade. As diferenças na produção de frutos não comerciais e no número de frutos comerciais foram significativas à $5 \%$ de probabilidade, enquanto que no número de frutos não comerciais não houve diferença significativa.

A aplicação de dióxido de carbono via água de irrigação influenciou positivamente a produtividade do meloeiro. Nos tratamentos com aplicação de $\mathrm{CO}_{2}$ houve maior produtividade do que nos tratamentos sem aplicação de $\mathrm{CO}_{2}$, para o mesmo tipo de manejo. As maiores produtividades obtidas nos tratamentos $T_{1}$ e $T_{2}$, com aplicação de $\mathrm{CO}_{2}$ diariamente e três vezes por semana, em relação ao tratamento $T_{3}$, foi devido ao maior número de frutos comerciais e os frutos com maior peso médio. Em ambiente sem nenhuma proteção e sem aplicação de $\mathrm{CO}_{2}$ verificou-se menor produtividade, 25,64 t.ha ${ }^{-1}$, enquanto que no ambiente com proteção lateral e aplicação diária de $\mathrm{CO}_{2}$ a produtividade foi de 38,59 tha ${ }^{-1}$ (Tabela 4). Sendo o $\mathrm{CO}_{2}$ mais denso que o ar e as plantas de melão de porte baixo, com folhas que cobrem a superficie do solo, é 
possível que o arraste de $\mathrm{CO}_{2}$ pelo vento seja menos intenso, permanecendo no ambiente da cultura por mais tempo e sendo absorvido pelas folhas das plantas.

Tabela 4. Produtividade total $(\mathrm{Pt})$, produtividade comercial $(\mathrm{Pc})$, produtividade não comercial (Pnc), peso médio de frutos comerciais (Pemf), número total de frutos $(\mathrm{Ntf})$ e número de frutos comerciais $(\mathrm{Nfc})$ em meloeiro cultivado em condições de campo.

\begin{tabular}{|c|c|c|c|c|c|c|}
\hline Trat. & $\mathrm{Pt}^{*}\left(\mathrm{t} \cdot \mathrm{ha}^{-1}\right)$ & $\mathrm{Pc}^{*}\left(\mathrm{t} \cdot \mathrm{ha}^{-1}\right)$ & $\operatorname{Pnc}^{*}\left(\right.$ t.ha $\left.^{-1}\right)$ & Pemf* (kg) & Ntf.ha ${ }^{-1}$ & Nfc.ha ${ }^{-1}$ \\
\hline $\mathrm{T}_{1}$ & $38,59 \mathrm{~A}=$ & $34,77 \mathrm{~A}$ & $3,82 \mathrm{AB}$ & $1,11 \mathrm{~A}$ & $37000 \mathrm{~A}$ & $34765 A$ \\
\hline $\mathrm{T}_{2}$ & $37,08 \mathrm{AB}$ & $32,69 \mathrm{AB}$ & $4,39 \mathrm{AB}$ & $1,04 \mathrm{AB}$ & $33500 \mathrm{ABC}$ & $32685 \mathrm{AB}$ \\
\hline $\mathrm{T}_{3}$ & $31,39 \mathrm{CD}$ & $28,42 \mathrm{BCD}$ & $2,97 \mathrm{AB}$ & $0,89 \mathrm{C}$ & $35500 \mathrm{AB}$ & $28417 \mathrm{ABC}$ \\
\hline $\mathrm{T}_{4}$ & $34,03 \mathrm{BC}$ & $31,78 \mathrm{AB}$ & $2,24 \mathrm{~B}$ & $1,00 \mathrm{ABC}$ & $32500 \mathrm{ABC}$ & $31777 \mathrm{AB}$ \\
\hline$T_{5}$ & $32,67 \mathrm{CD}$ & $29,56 \mathrm{ABC}$ & $3,11 \mathrm{AB}$ & $1,02 \mathrm{AB}$ & $33250 \mathrm{ABC}$ & $29560 \mathrm{ABC}$ \\
\hline $\mathrm{T}_{6}$ & $29,67 \mathrm{DE}$ & $23,36 \mathrm{DE}$ & $6,31 \mathrm{~A}$ & $0,97 \mathrm{~B}$ & $30500 \mathrm{BC}$ & $23558 \mathrm{DC}$ \\
\hline$T_{7}$ & $32,17 \mathrm{CD}$ & $28,35 \mathrm{BCD}$ & $3,82 \mathrm{AB}$ & $1,01 \mathrm{ABC}$ & $31750 \mathrm{BC}$ & $28352 \mathrm{ABC}$ \\
\hline$T_{8}$ & $29,69 \mathrm{DE}$ & $25,92 \mathrm{CDE}$ & $3,77 \mathrm{AB}$ & $0,93 \mathrm{BC}$ & $32250 \mathrm{ABC}$ & $25917 \mathrm{BCD}$ \\
\hline $\mathrm{T}_{9}$ & $25,64 \mathrm{E}$ & $20,40 \mathrm{E}$ & $5,24 \mathrm{AB}$ & $0,88 \mathrm{C}$ & $29000 \mathrm{C}$ & 20400D \\
\hline$\overline{C V}(\%)$ & $\overline{5,52}$ & 8,53 & $\overline{39,72}$ & 5,35 & $\overline{6,93}$ & 7,09 \\
\hline
\end{tabular}

* Para cada coluna, as médias seguidas pela mesma letra não diferiram entre si, à $5 \%$ de probabilidade, pelo teste de Tukey.

Verificou-se, também, que a produtividade total do tratamento $T_{1}$ (com aplicação diariamente de $\mathrm{CO}_{2}$ ) foi $22,9 \%$ maior que o tratamento $\mathrm{T}_{3}$ (sem aplicação de $\mathrm{CO}_{2}$ ) em cultivo com proteção lateral. Fazendo a mesma comparação para os tratamentos $T_{4}$ e $T_{6}$ (solo coberto com plástico) e, para $T_{7}$ e $T_{9}$, (solo sem nenhuma proteção) verificou-se aumento de 14,7 e $25,5 \%$, respectivamente.

A produtividade total em cultivo com proteção lateral e aplicação diária de $\mathrm{CO}_{2}$ $\left(\mathrm{T}_{1}\right)$ foi $50,9 \%$ maior em relação ao cultivo sem nenhuma proteção e sem aplicação de $\mathrm{CO}_{2}\left(\mathrm{~T}_{9}\right)$ (Tabela 4$)$. 
Comparando a produtividade comercial do tratamento $T_{1}$ com a do tratamento $T_{9}$ observou-se que o aumento foi $70,4 \%$. Tal fato está relacionado com o aumento de $37 \%$ no número de frutos e de $26 \%$ no peso individual dos frutos no tratamento $T_{1}$ em relação ao $\mathrm{T}_{9}$.

Considerando-se a produtividade comercial o incremento de $T_{1}$ em relação ao tratamento $T_{3}$ foi de $22,3 \%$, de $T_{4}$ em relação a $T_{6}$ foi de $36,0 \%$ e de $T_{7}$ em relação a $T_{9}$ foi de $39,0 \%$. Para número total de frutos, o incremento de $T_{1}$ em relação a $T_{3}$ foi de $4,2 \%$, de $T_{4}$ para $T_{6}$ o aumento foi de $6,7 \%$ e de $T_{7}$ em relação a $T_{9}$ foi de $9,9 \%$. O peso médio dos frutos também foi afetado pelos tratamentos, constatando-se incremento de $24,7 \%$ para o tratamento $T_{1}$ em relação ao $T_{3}, 3,1 \%$ para $T_{4}$ comparado ao $T_{6}, 14,8 \%$ para $T_{7}$ em relação ao $T_{9}$. A aplicação do $\mathrm{CO}_{2}$, mesmo a céu aberto, foi benéfica para a produção da cultura, o que pode ser comprovado comparando as produtividade dos tratamentos $\mathrm{T}_{7}, \mathrm{~T}_{8}$ e $\mathrm{T}_{9}$. Além do efeito do $\mathrm{CO}_{2}$, em ambiente protegido as plantas sofrem menor influência do vento, e, possivelmente, menor variação da temperatura no dossel vegetativo. Também, quando da ocorrência de precipitações pluviométricas intensas, a cultura fica protegida de águas de escoamento superficial, que além de danificar as folhas, flores e frutos em fase inicial de desenvolvimento, impregnam-nas com terra, prejudicando o desenvolvimento normal das plantas e reduzindo a produtividade. A cobertura do solo com plástico possivelmente contribuiu para evitar a difusão do $\mathrm{CO}_{2}$, porém não protege a cultura dos efeitos de fortes chuvas, pois o solo arrastado pelas águas de chuva afetavam as plantas. Contudo, protege as folhas e flores do arraste de partículas de solo.

A produtividade total e comercial do tratamento $T_{3}$ (com proteção lateral e sem aplicação de $\left.\mathrm{CO}_{2}\right)$ foi superior à produtividade da testemunha $\left(\mathrm{T}_{9}\right.$, sem nenhuma proteção e sem aplicação de $\mathrm{CO}_{2}$ ). $\mathrm{O}$ incremento na produtividade total foi de $22,42 \%$ e na produtividade comercial foi de 39,31\%. Observou-se (Tabela 4) maior número de frutos comerciais, confirmando a eficácia da proteção lateral em evitar danos e desbaste natural de flores e frutos em sua fase inicial de desenvolvimento.

$\mathrm{O}$ índice de aproveitamento comercial da produção para os tratamentos $T_{1}, T_{2}$, $\mathrm{T}_{3}, \mathrm{~T}_{4}, \mathrm{~T}_{5}, \mathrm{~T}_{6}, \mathrm{~T}_{7}, \mathrm{~T}_{8}$ e $\mathrm{T}_{9}$ foram: 0,$90 ; 0,88 ; 0,90 ; 0,93 ; 0,90 ; 0,79 ; 0,88 ; 0,87$ e 0,80 , 
respectivamente. A ocorrência de maiores índice de colheita nos tratamentos com aplicação de dióxido de carbono deveu-se ao maior número e maior peso médio de frutos comerciais, exceto no tratamento $\mathrm{T}_{3}$, sem aplicação de $\mathrm{CO}_{2}$, no qual observou-se menor peso médio de frutos, porém maior número de frutos comerciais e, conseqüentemente, menor produção de frutos não comerciais.

As plantas respondem à atmosfera enriquecida com $\mathrm{CO}_{2}$ devido ao incremento da taxa de assimilação de $\mathrm{CO}_{2}$ ao aumentar a atividade de carboxilação da enzima Ribulose bisfosfato carboxilase-oxigenose, reduzindo a fotorrespiração e, conseqüentemente aumentando a produção de fotoassimilados, o crescimento e a produção. Também, o incremento do dióxido de carbono na atmosfera do solo induz a redução do $\mathrm{pH}$ do solo permitindo maior mobilidade de elementos nutritivos (Basile et al., 1993). O dióxido de carbono possui comportamento de quelato, podendo associar-se a elementos do solo como cálcio, cobre, ferro, magnésio manganês e cobalto, formando complexos facilmente carreáveis até as raízes das plantas para absorção (Moore, 1990).

Sendo a aplicação dióxido de carbono uma prática relativamente simples, torna-se mais uma opção para uso intensivo do sistema de irrigação, permitindo diluir seus custos de implantação com redução dos custos de produção.

Não houve efeitos significativos para as características químicas como $\mathrm{pH}$, acidez total e teor de sólidos solúveis, constatado pela análise de variância.

Os aspectos qualitativos dos frutos de melão foram analisados através do teor de sólidos solúveis ( ${ }^{\circ} \mathrm{Brix}$ ), acidez total e pH. Para Yamaguch et al. (1977) o teor de sólidos solúveis é o principal fator que determina a qualidade dos frutos. $\mathrm{O}$ teor de sólidos solúveis mínimo para exportação é $9^{\circ} \mathrm{Brix}$, com o valor ideal de $13^{\circ} \mathrm{Brix}$ (Bleinroth, 1994). Aulenbauch \& Worthington (1974) questionam o teor de sólidos solúveis como único critério para definir a qualidade dos frutos, contudo sugerem a faixa considerada ideal entre 8 e $13^{\circ}$ Brix. O valor médio do teor de sólidos solúveis na colheita foi de $11,87^{\circ}$ Brix e, $11,84,11,92$ e $12,14^{\circ}$ Brix, durante o armazenamento aos 10,20 e 30 dias após a colheita, respectivamente. $\mathrm{O}$ teor de sólidos solúveis varia em conseqüência do conteúdo de açúcares totais durante o armazenamento (Sheillie \& Saltveit Jr., 1993). 
Os valores de teor de sólidos solúveis obtidos foram superiores aos encontrados por Buzetti et al. (1993), Souza (1993), todavia, o teor de sólidos solúveis varia tanto com as condições de clima e solo do local de plantio, quanto de fruto para fruto em diferentes plantas (Davis \& Schweers, 1971).

A acidez total foi de $0,19,0,17,0,16$ e $0,17 \%$, na colheita e, no armazenamento, aos 10,20 e 30 dias após a colheita, respectivamente. Esses valores atendem às exigências do mercado externo. $\mathrm{E} \circ \mathrm{pH}$ foi de 5,63, 5,69, 5,73 e 5,83, na colheita e, armazenamento as 10,20 e 30 dias após a colheita respectivamente. Estes valores assemelham-se àqueles obtidos por Micollis \& Saltveit Jr. (1991) e Lester \& Shellie (1992), para melão amarelo. O tempo de vida útil de pós-colheita superior a 30 dias é suficiente para a comercialização do produto nos mercados interno e externo. $O$ índice de maturidade utilizado é recomendado por Menezes et al. (1995) e os resultados encontrados são consistentes com os obtidos em trabalhos com melão amarelo (Ryall \& Lipton, 1972; Silva, 1992 e Gonçalves, 1994).

A relação teor de sólidos solúveis/acidez total é usada para avaliar tanto o estado de maturação quanto a palatabilidade dos frutos. Se essa relação estiver acima de 25 e a acidez total estiver abaixo de $0,5 \%$, o fruto terá bom sabor e boa coloração. Os valores encontrados satisfazem as preferências dos consumidores brasileiros, que preferem frutos mais adocicados e menos ácidos (Salomão et al., 1988).

\subsection{3- Análise química das folhas}

As concentrações de nutrientes são variáveis em diferentes partes da planta. Mas como a maioria dos processos fisiológicos para a produção são realizados nas folhas, a avaliação do seu conteúdo em nutrientes reflete o estado nutricional das plantas (Malavolta et al., 1989; Raij, 1991).

Verificou-se (Tabela 5) que os tratamentos utilizados não causaram diferenças significativas entre os elementos nutricionais analisados, exceto o boro, o qual foi superior para o tratamento com solo nu e sem aplicação de dióxido de carbono. 
Tabela 5. Teores de nutrientes em folhas de meloeiro, na época da frutificação, média de quatro repetições.

\begin{tabular}{|c|c|c|c|c|c|c|c|c|c|c|c|}
\hline \multirow[t]{2}{*}{ Trat. } & $\mathbf{N}$ & $P$ & $\mathrm{~K}$ & $\mathrm{Ca}$ & $\mathrm{Mg}$ & $\mathrm{S}$ & B & $\mathrm{Cu}$ & $\mathrm{Fe}$ & Mn & $\mathrm{Zn}$ \\
\hline & \multicolumn{6}{|c|}{ 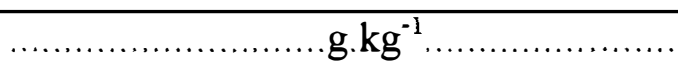 } & \multicolumn{5}{|c|}{$\mathrm{mg} \cdot \mathrm{kg}^{-1}$} \\
\hline T1 & 35,5 & 4,6 & 51,7 & 38,4 & 15,4 & 4,5 & $18,5 \mathrm{~B}$ & 16,0 & 945,5 & 360,0 & 36,75 \\
\hline $\mathrm{T} 2$ & 32,2 & 4,3 & 44,2 & 35,3 & 15,1 & 4,1 & $20,7 \mathrm{~B}$ & 16,2 & 887,7 & 347,0 & 36,75 \\
\hline T3 & 30,0 & 4,5 & 46,7 & 38,0 & 16,4 & 4,8 & $21,7 \mathrm{~B}$ & 15,7 & 900,5 & 442,2 & 36,50 \\
\hline $\mathrm{T} 4$ & 31,0 & 4,5 & 45,1 & 37,4 & 15,2 & 4,7 & $25,2 \mathrm{AB}$ & 14,7 & 1198,7 & 387,5 & 36,50 \\
\hline T5 & 30,6 & 4,2 & 45,6 & 34,5 & 15,3 & 4,6 & $19,5 \mathrm{~B}$ & 16,7 & 837,0 & 344,8 & 36,50 \\
\hline T6 & 32,6 & 4,0 & 44,4 & 37,6 & 16,8 & 4,3 & $24,2 \mathrm{AB}$ & 16,2 & 909,2 & 369,8 & 36,25 \\
\hline $\mathrm{T} 7$ & 29,9 & 4,7 & 44,0 & 38,5 & 17,0 & 4,6 & $28,2 \mathrm{AB}$ & 15,5 & 990,5 & 332,8 & 38,25 \\
\hline T8 & 29,5 & 4,8 & 42,8 & 35,6 & 15,2 & 4,4 & $28,7 \mathrm{AB}$ & 16,2 & 760,2 & 335,8 & 37,25 \\
\hline T9 & 33,0 & 5,0 & 46,7 & 38,1 & 15,8 & 4,0 & $32,2 \mathrm{~A}$ & 15,5 & 863,0 & 304,8 & 36,75 \\
\hline$\overline{\mathrm{CV}(\%)}$ & 8,59 & 11,40 & 12,70 & 4,89 & 0,19 & 13,61 & 17,60 & 10,05 & 21,67 & 18,46 & 5,48 \\
\hline
\end{tabular}

* Para cada coluna, as médias seguidas pela mesma letra não diferiram entre si, à $5 \%$ de probabilidade, pelo teste de Tukey.

Belfort (1985) observou aos 60 dias, em folhas localizada na mesma posição, os seguintes valores: $\mathrm{N}\left(29,5 \mathrm{~g} \cdot \mathrm{kg}^{-1}\right), \mathrm{P}\left(3,3 \mathrm{~g} \cdot \mathrm{kg}^{-1}\right)$ e $\mathrm{K}\left(32,5 \mathrm{~g} \cdot \mathrm{kg}^{-1}\right)$. Verificou-se que os valores das concentrações de $\mathrm{N}$ determinadas neste estudo, da ordem de $30 \mathrm{~g} . \mathrm{kg}^{-1} \mathrm{MS}$, concordando com o resultado obtido por Belfort (1985), as concentrações de fósforo $\left(4,5 \mathrm{~g} \cdot \mathrm{kg}^{-1}\right)$ e de potássio $\left(45,6 \mathrm{~g} \cdot \mathrm{kg}^{-1}\right)$ foram maiores. Os valores das concentrações de $\mathrm{Ca}$ $\left(37,1 \mathrm{~g} \cdot \mathrm{kg}^{-1}\right), \mathrm{S}\left(2,6 \mathrm{~g} \cdot \mathrm{kg}^{-1}\right)$ e $\mathrm{Mg}\left(10,5 \mathrm{~g} \cdot \mathrm{kg}^{-1}\right)$, encontrados por Belfort (1985) foram inferiores na média em $17 \%, 50 \%$ e $30 \%$, respectivamente, em relação aos valores obtidos neste estudo (Tabela 5).

Para os elementos N, P e K, Malavolta et al. (1989), sugeriram que os teores ideais desses elementos nas folhas do meloeiro sejam equivalentes a $30 \mathrm{~g} \cdot \mathrm{kg}^{-1}, 3,5 \mathrm{~g} \cdot \mathrm{kg}^{-1} \mathrm{e}$ 50 g. $\mathrm{kg}^{-1}$, respectivamente. Dessa forma, os teores de $\mathrm{N}$ aqui obtidos, foram próximos ou 
superiores àqueles considerados ideais, os teores de $\mathrm{P}$ superiores e os teores de $\mathrm{K}$ menores, concordando com os resultados obtidos por Souza (1993).

Tyler \& Lorenz (1964) obtiveram maiores valores para concentração de N no início da frutificação, decrescendo até a colheita. $O$ teor de nitrogênio em folhas novas é mais elevado do que nas folhas adultas (Belfort, 1985), que observou tendência linear de queda na concentração de $\mathrm{N}$. Maiores acúmulos foram verificados no período entre $30 \mathrm{e}$ 45 dias.

A concentração de $\mathrm{P}$, superior à considerada ideal, deve-se, provavelmente, à influência da irrigação freqüente na solubilidade e mobilidade desse elemento no sistema solo-planta. Belfort (1985) constatou redução no teor de P a partir do início da frutificação. Para Tyler \& Lorenz (1964) a concentração foi mais elevada aos 51 dias (6,2 g. $\left.\mathrm{kg}^{-1}\right)$, caindo até $3,2{\mathrm{~g} . \mathrm{kg}^{-1}}^{1}$ aos 107 dias.

A concentração de potássio encontrada foi inferior à considerada ideal. Tyler \& Lorenz (1964) verificaram que a concentração do $\mathrm{K}$ na folha eleva-se até aos 51 dias atingindo cerca de 3,09\%, reduzindo-se até o final do ciclo.

Para os demais elementos químicos analisados não foi possivel encontrar na literatura referências relativas a teores ideais ou críticos para o meloeiro. Os valores encontrados para o cálcio (valores entre 34,5 e $38,5 \mathrm{~g} \cdot \mathrm{kg}^{-1}$, para os diferentes tratamentos) estão próximos, enquanto que os valores do magnésio (variando de 15,2 a $17 \mathrm{~g}^{\mathrm{kg}}{ }^{-1}$ ) são o dobro dos obtidos por Souza (1993), 35,8 e 7,1 g. $\mathrm{kg}^{-1}$ para o cálcio e magnésio, respectivamente. Belfort (1985) observou aumento progressivo no teor de cálcio com a idade da planta, atingindo valor da ordem de 30 g. $\mathrm{kg}^{-1}$. Tyler \& Lorenz (1964) encontraram uma tendência semelhante para o comportamento do cálcio, entretanto, os valores obtidos foram muito menores ficando em torno de $5 \mathrm{~g} \cdot \mathrm{kg}^{-1}$. Para o magnésio Belfort (1985) encontrou valores da ordem de $10 \mathrm{~g}_{\mathrm{kg}}{ }^{-1}$, mantendo-se constante durante todo ciclo da cultura.

Belfort (1985) verificou tendência de acúmulo de enxofre após o período de frutificação, nessa fase a concentração de enxofre nas folhas foi de $2 \mathrm{~g}^{\mathrm{kg}} \mathrm{kg}^{-1}$, valor esse que corresponde à metade do valor aqui encontrado $\left(4,4 \mathrm{~g} \cdot \mathrm{kg}^{-1}\right)$. 
Valores de boro encontrados por Belfort (1985) foram da ordem de $55 \mathrm{mg} . \mathrm{kg}^{-1} \mathrm{na}$ floração, chegando a $77 \mathrm{mg} \cdot \mathrm{kg}^{-1}$ na frutificação. O boro foi o único elemento que apresentou diferenças significativas entre os tratamentos, com valores variando de 18,5 $\mathrm{mg} \cdot \mathrm{kg}^{-1}$ (com aplicação diária de $\mathrm{CO}_{2}$ e proteção lateral) a $32,25 \mathrm{mg} \cdot \mathrm{kg}^{-1}$ (solo nu e sem aplicação $\mathrm{CO}_{2}$ ), inferiores aos valores obtidos por Belfort (1985).

Comparativamente os teores de $\mathrm{Cu}\left(17,3 \mathrm{mg} \cdot \mathrm{kg}^{-1}\right), \mathrm{Fe}\left(581,3 \mathrm{mg} \cdot \mathrm{kg}^{-1}\right), \mathrm{Mn}(271,0$ mg.kg $\left.{ }^{-1}\right)$ e $\mathrm{Zn}\left(42,8 \mathrm{mg} \cdot \mathrm{kg}^{-1}\right)$ observados por Belfort (1985) foram semelhantes aos aqui obtidos para o $\mathrm{Cu}\left(16,0 \mathrm{mg} \cdot \mathrm{kg}^{-1}\right)$ e diferentes em relação ao $\mathrm{Fe}\left(921,4 \mathrm{mg} \cdot \mathrm{kg}^{-1}\right), \mathrm{Mn}$ (358,3 mg.kg-1) e $\mathrm{Zn}\left(36,8 \mathrm{mg} \cdot \mathrm{kg}^{-1}\right)$.

Tyler \& Lorenz (1964) determinaram as concentrações de N, P, K, Ca, e Mg em folhas do meloeiro em quatro variedades. Não houve diferença significativa entre os elementos analisados, sendo os valores médios encontrados: N 46,1; P 5,9; K 26; Ca 5,1 e $\mathrm{Mg} 7,1$, em g. $\mathrm{kg}^{-1} \mathrm{MS}$. Bella (1985) também em folhas de meloeiro encontrou os seguintes valores: N 28; P 2,6; K 35,4 Ca 53,9 e Mg 4,5, em g. $\mathrm{kg}^{-1} \mathrm{MS}$ e, para os micronutrientes: Mn 574; Fe 174; Zn 48 B 22 e Cu 9, em mg.kg-1.

Segundo Belfort (1985), a planta aloca expressiva quantidade de nutrientes no processo de frutificação. Este autor determinou as quantidades totais de $\mathrm{N}, \mathrm{P}, \mathrm{K}, \mathrm{Ca}, \mathrm{Mg}$ e S exportados pelos frutos: $302,2 \mathrm{~g} \cdot \mathrm{kg}^{-1}, 370,5 \mathrm{~g} \cdot \mathrm{kg}^{-1}, 337,8 \mathrm{~g} \cdot \mathrm{kg}^{-1}, 44,4 \mathrm{~g} \cdot \mathrm{kg}^{-1}, 150,5$ g. $\mathrm{kg}^{-1}$ e 223,8 g. $\mathrm{kg}^{-1}$, respectivamente. Ainda, de acordo com Belfort (1985), os micronutrientes também devem merecer atenção, principalmente zinco e ferro, em vista das quantidades exportadas $\left(49,20\right.$ e 53,60 g.ha $\left.{ }^{-1}\right)$. Na colheita foram removidos pelos frutos $14 \mathrm{~g} \cdot \mathrm{kg}^{-1}$ de B, 24,2 g. $\mathrm{kg}^{-1}$ de $\mathrm{Cu}, 58,1 \mathrm{~g} \cdot \mathrm{kg}^{-1}$ de Fe, 43,8 g.kg-1 de Mn e 255,4 g. $\mathrm{kg}^{-1}$ de $\mathrm{Zn}$.

Ghannoum et al. (1997) não verificaram diferenças na concentração de N para Panicum loxum e Panicum antidotale cultivadas em ambiente com baixa e alta concentração de $\mathrm{CO}_{2}$. Ocorrendo concordância com os resultados obtidos por Conroy (1992). Todavia, verifica-se diferenças de resultados na literatura, dependendo da espécie e das condições de cultivo. Wong (1990) encontrou redução na concentração $\mathrm{N}$ total por unidade de área foliar, Sage et al. (1989) não verificaram diferenças para espécies $C_{3}$. Enquanto Roger et al. (1996) observaram aumento na concentração de nitrogênio. 


\subsection{4- Eficiência no uso de água para as condições de campo}

A lâmina total de água aplicada através da irrigação, no período do transplantio até a colheita foi de $201,8 \mathrm{~mm}$. A evaporação da água, neste período, foi de $329,8 \mathrm{~mm}$, medida no tanque classe A. Houve um total de $94,7 \mathrm{~mm}$ de precipitação pluvial, ocorrida com maior frequeência na época do transplantio. Os valores dos parâmetros climáticos ocorridos durante a realização do experimento são mostrado na Tabela 9 (Anexo). Na Figura 11 pode-se visualizar o comportamento da evapotranspiação cultural (ETc) e na Figura 12 os valores de água aplicada por dia durante o período de duração do experimento.

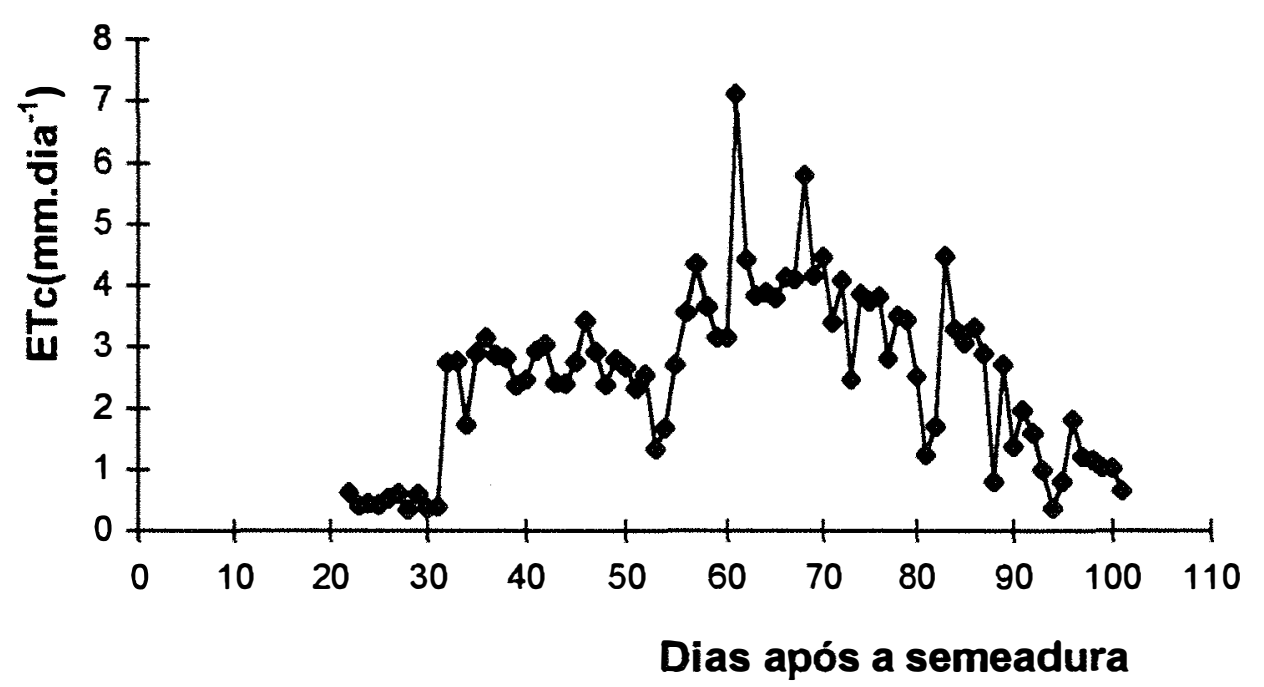

Figura 11. Evapotranspiração da cultura estimada pelo Tanque Classe A, para a cultura do meloeiro. Piracicaba, no período entre 11/03 e 31/05/1996.

Os valores encontrados para eficiência no uso de água $\left(\mathrm{kg} \cdot \mathrm{m}^{-3}\right)$ foram: 13,01 ; 12,$50 ; 10,58 ; 11,48 ; 11,02 ; 10,01 ; 10,85 ; 10,01$ e 8,65 para os tratamentos $T_{1}, T_{2}, T_{3}, T_{4}$, $\mathrm{T}_{5}, \mathrm{~T}_{6}, \mathrm{~T}_{7}, \mathrm{~T}_{8}$ e $\mathrm{T}_{9}$, respectivamente. Hernandez (1995) encontrou valores variando de 17,23 a 19,82, portanto, acima dos valores obtidos e Ritschel et al. (1994) obteve valores 
de eficiência de uso de água variando entre 5,50 e $19,82 \mathrm{~kg} \cdot \mathrm{m}^{-3}$ para a cultura do melão. Esta variação na eficiência do uso de água, os autores atribuíram à diferenças na demanda evaporativa, devido a plantio em épocas distintas e, conseqüentemente, aumento na necessidade de aplicação de maiores quantidades de água.

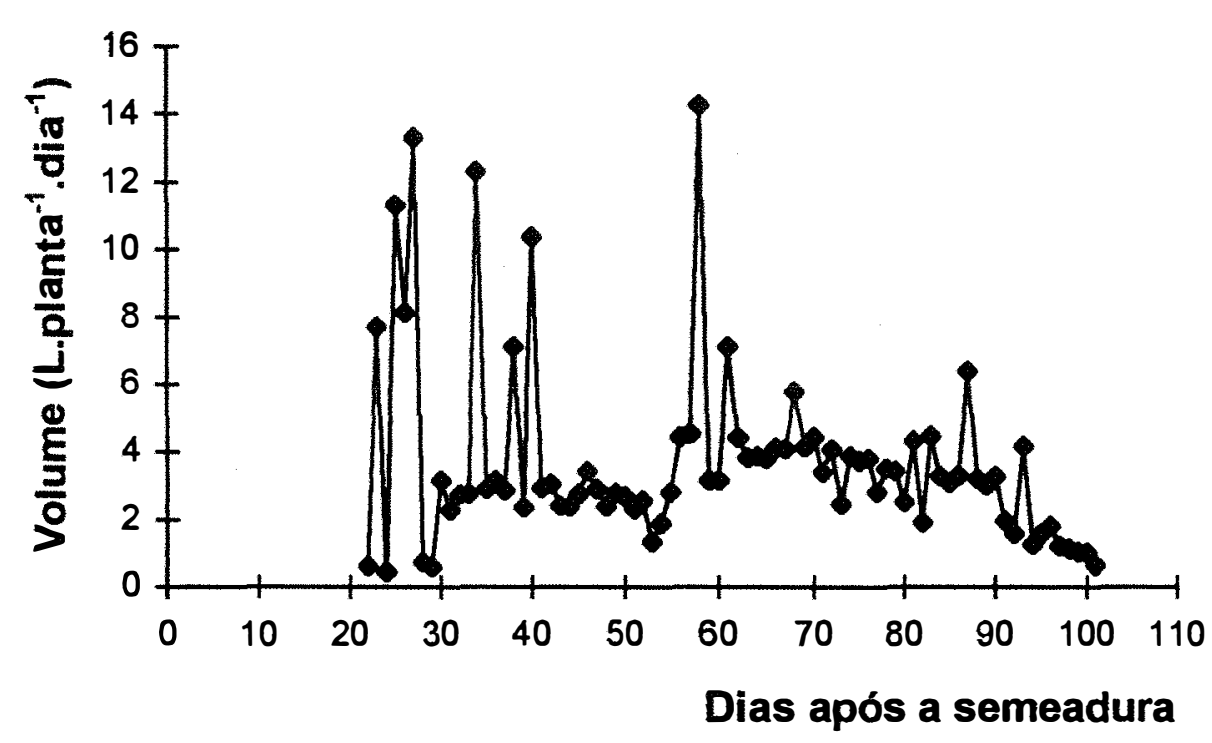

Figura 12- Volume de água aplicado em meloeiro cultivado em condições de campo durante o experimento. Piracicaba, no período entre 11/03 e 31/05/1996.

4.4- Aplicação de dióxido de carbono via água de irrigação em meloeiro em condições de ambiente protegido

\subsection{1- Desenvolvimento da cultura}

O ciclo fenológico da cultura foi de 115 dias. Foram realizadas duas colheitas: 101 e 115 dias após a semeadura. No experimento realizado em condições de campo o ciclo fenológico da cultura foi de 105 dias. Hernandez (1995), em Ilha Solteira, utilizando o sistema de formação de mudas, com posterior transplantio para o campo, encontrou 
ciclo de cultura variando de 101 e 108 dias, com três colheitas. Houve períodos com ocorrência de baixas temperaturas durante o período de florescimento e frutificação (Tabela 10, Anexo) que podem ter contribuído para prolongar o ciclo da cultura.

\subsection{2- Aspectos produtivos}

Verificou-se, pela análise de variância, que as diferenças na produtividade total, produtividade comercial, número de frutos comerciais e não comerciais foram significativas a $1 \%$ de probabilidade. As diferenças na produtividade não comercial e no peso médio de frutos comerciais foram significativos a $5 \%$ de probabilidade, enquanto número de frutos total não o foi.

A aplicação $\mathrm{CO}_{2}$ via água de irrigação influenciou positivamente a produtividade do meloeiro. O tratamento com aplicação de dióxido de carbono proporcionou maior produtividade de frutos (total, comercial e não comercial) em comparação com $o$ tratamento sem aplicação de dióxido de carbono (Tabela 6).

Tabela 6. Produtividade total $(\mathrm{Pt})$, produtividade comercial $(\mathrm{Pc})$, produtividade não comercial (Pnc), peso médio de frutos comerciais (Pemf), número total de frutos (Ntf) e número de frutos comerciais $(\mathrm{Nfc})$, em meloeiro cultivado em ambiente protegido com e sem aplicação de $\mathrm{CO}_{2}$ na água de irrigação.

\begin{tabular}{ccccccc}
\hline Trat. & $\mathrm{Pt}^{*}\left(\mathrm{t} \cdot \mathrm{ha}^{-1}\right)$ & $\mathrm{Pc}^{*}\left(\mathrm{t} \cdot \mathrm{ha}^{-1}\right)$ & $\mathrm{Pnc}^{*}\left(\mathrm{t} \cdot \mathrm{ha}^{-1}\right)$ & $\mathrm{Pemf}^{*}(\mathrm{~kg})$ & $\mathrm{Ntc}^{*} \cdot \mathrm{ha}^{-1}$ & $\mathrm{Nfc}^{*} \cdot \mathrm{ha}^{-1}$ \\
\hline $\mathrm{Com} \mathrm{CO}_{2}$ & $28,68 \mathrm{~A}$ & $23,68 \mathrm{~A}$ & $5,00 \mathrm{~A}$ & $0,875 \mathrm{~A}$ & $42330 \mathrm{~A}$ & $34500 \mathrm{~A}$ \\
$\mathrm{Sem} \mathrm{CO}$ & $22,53 \mathrm{~B}$ & $19,67 \mathrm{~B}$ & $2,86 \mathrm{~B}$ & 0,800 & $36310 \mathrm{~B}$ & $30170 \mathrm{~B}$ \\
\hline C.V. (\%) & 5,05 & 4,90 & 34,75 & 5,20 & 5,99 & 6,13
\end{tabular}

* Para cada coluna, as médias seguidas pela mesma letra não diferiram entre si, à $5 \%$ de probabilidade, pelo teste de Tukey. 
A maior produtividade do tratamento com aplicação de $\mathrm{CO}_{2}$ deveu-se ao maior número e peso médio de frutos comerciais. No tratamento com aplicação de $\mathrm{CO}_{2}$ via água de irrigação a taxa de assimilação de $\mathrm{CO}_{2}$ foi maior no horário de aplicação de $\mathrm{CO}_{2}$ e iguais no demais horários (Tabela 7).

Tabela 7. Taxa de assimilação de $\mathrm{CO}_{2}$ média $\left(\mu \mathrm{mol} \cdot \mathrm{m}^{-2} \cdot \mathrm{s}^{-1}\right)$ em meloeiro nos diferentes horários, cultivado em ambiente protegido com e sem $\mathrm{CO}_{2}$ via água de irrigação.

\begin{tabular}{cccccc}
\hline Trat. & $10 \mathrm{~h}$ & $11 \mathrm{~h}^{*}$ & $12 \mathrm{~h}$ & $14 \mathrm{~h}$ & Geral* \\
\hline $\mathrm{Com} \mathrm{CO}_{2}$ & 10,81 & $16,55 \mathrm{~A}$ & 13,91 & 10,93 & $13,56 \mathrm{~A}$ \\
$\mathrm{Sem} \mathrm{CO}_{2}$ & 11,68 & $13,54 \mathrm{~B}$ & 12,94 & 10,78 & $12,39 \mathrm{~B}$ \\
\hline C.V. (\%) & 14,90 & 13,08 & 16,62 & 17,05 & 20,89 \\
\hline
\end{tabular}

* Para cada coluna, as médias seguidas pela mesma letra não diferiram entre si, à $5 \%$ de probabilidade, pelo teste de Tukey.

Acock et al., (1990) observaram que a aplicação de dióxiodo de carbono em melão proporcionou aumento de área foliar, aumento de matéria seca da folha, produção de maior número de células paliçadicas nas folhas, com incremento da eficiência na fotossintese . Ghannoum et al. (1997) observaram que concentrações de $\mathrm{CO}_{2}$ acima de $700 \mu \mathrm{molCO}_{2} \cdot \mathrm{mol}^{-1}$ provocaram reduções de até $50 \%$ na condutância estomática.

Não houve efeitos significativos detectado pela análise de variância para $\mathrm{pH}$, acidez total e teor de sólidos solúveis nos frutos de melão cultivado em ambiente protegido com e sem aplicação de $\mathrm{CO}_{2}$ via água de irrigação.

O valor médio do teor de sólidos solúveis na colheita foi 10,26 com aplicação de $\mathrm{CO}_{2}$ e 9,87 sem aplicação de $\mathrm{CO}_{2}$, a acidez média foi de 0,20 e 0,19 , respectivamente e o pH médio foi de 5,92 e 5,76, respectivamente. Estes valores estão de acordo com os valores encontrados por Micollis \& Salveit Jr. (1991), Lester \& Shellie (1992). Também assemelham-se aos valores encontrados no experimento de campo com aplicação de $\mathrm{CO}_{2}$ via água de irrigação. 


\subsection{3- Análise química das folhas}

Coletou-se, na fase de frutificação, uma amostra composta em cada tratamento para análise química de folha. Os resultados são mostrados na Tabela 8. A concentração de potássio foi $94,2 \%$ maior com aplicação de $\mathrm{CO}_{2}$ via água de irrigação, estando, porém, próximo do valor encontrado por Tyler \& Lorenz (1964). Com a concentração do ferro ocorreu o contrário, ou seja, foi $64,9 \%$ menor com aplicação de $\mathrm{CO}_{2}$ via água de irrigação.

Tabela 8. Teores de nutrientes em folhas de meloeiro cultivado em ambiente protegido, com e sem aplicação de $\mathrm{CO}_{2}$ via água de irrigação.

\begin{tabular}{|c|c|c|c|c|c|c|c|c|c|c|c|}
\hline \multirow[t]{2}{*}{ Trat } & $\mathrm{N}$ & $P$ & K & $\mathrm{Ca}$ & $\mathrm{Mg}$ & $S$ & B & $\mathrm{Cu}$ & $\mathrm{Fe}$ & $\mathrm{Mn}$ & $\mathrm{Zn}$ \\
\hline & \multicolumn{6}{|c|}{$\ldots . . \mathrm{g} \cdot \mathrm{kg}^{-1}}$. & \multicolumn{5}{|c|}{$\mathrm{mg} \cdot \mathrm{kg}^{-1}$} \\
\hline $\mathrm{Com} \mathrm{CO} 2$ & 42,3 & 3,8 & 50,5 & 38,2 & 9,6 & 2,0 & 12 & 13 & 161 & 151 & 36 \\
\hline $\mathrm{Sem} \mathrm{CO}{ }_{2}$ & 35,7 & 4,2 & 26 & 41,6 & 10,2 & 1,6 & 14 & 14 & 248 & 166 & 33 \\
\hline
\end{tabular}

\subsection{4- Eficiência no uso de água para as condições de ambiente protegido}

A lâmina total de água aplicada através da irrigação, no período do transplantio à colheita foi de $236,1 \mathrm{~mm}$ e a evaporação medida em um tanque tipo classe A modificado foi de 206,9 mm. Na Figura 13 pode-se visualizar o comportamento da evapotranspiração da cultura (ETc) e na Figura 14 os valores de água aplicada por dia durante o período de duração do experimento. 


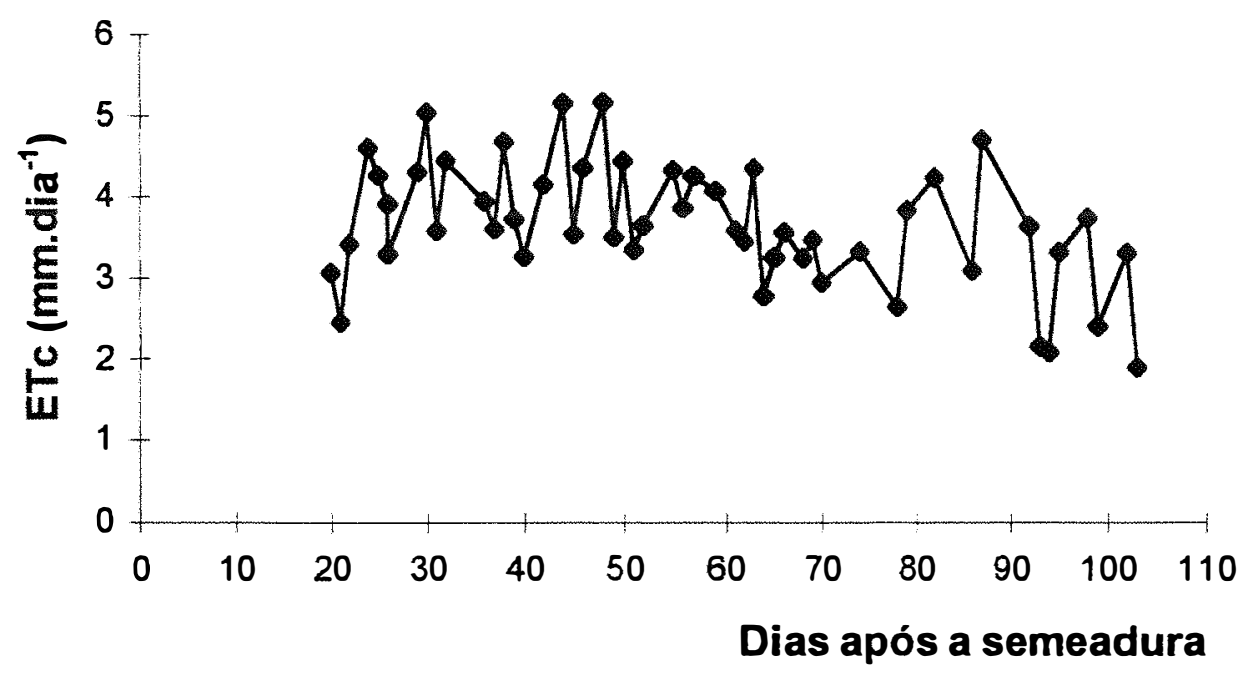

Figura 13. Evapotranspiração da cultura estimada pelo Tanque Classe A, para a cultura do meloeiro, em ambiente protegido. Piracicaba, no período entre 16/04 e 26/06/1997.

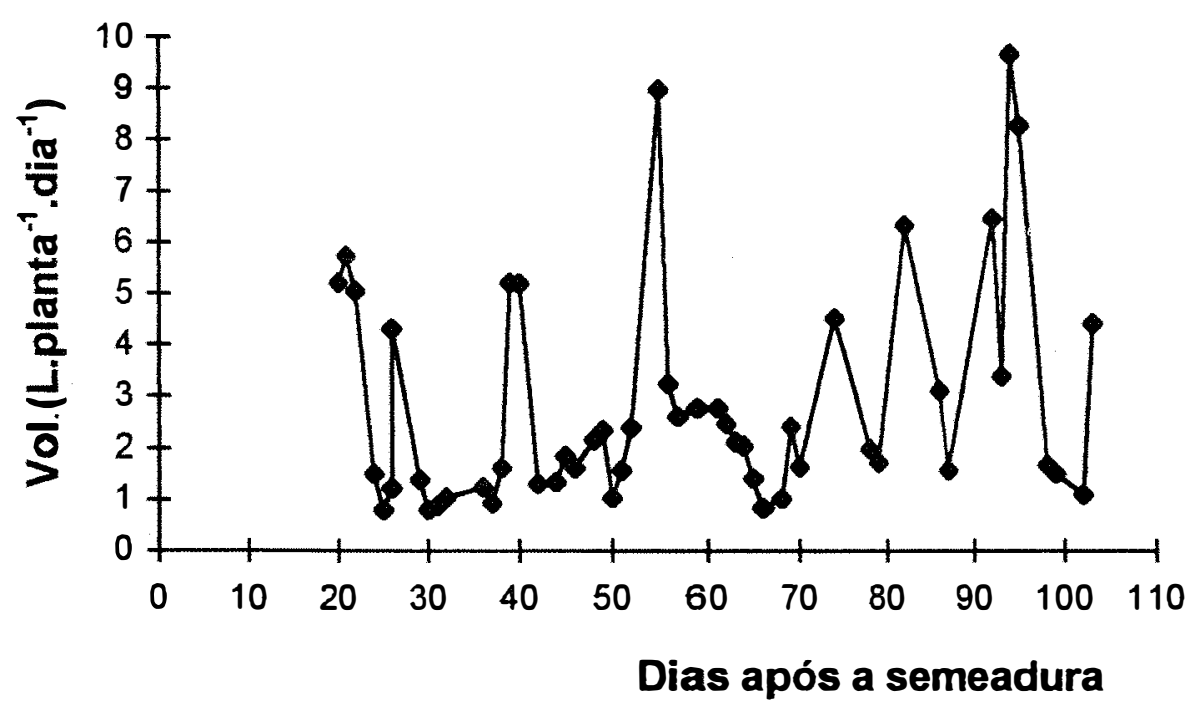

Figura 13. Volume de água aplicado em meloeiro cultivado em ambiente protegido com e sem aplicação de $\mathrm{CO}_{2}$ durante o experimento. Piracicaba, no período entre $16 / 04$ e 26/06/1997. 
Os valores encontrados para eficiência no uso de água $\left(\mathrm{kg} \cdot \mathrm{m}^{-3}\right)$ foram: $12,15 \mathrm{e}$ 9,54 com e sem aplicação de $\mathrm{CO}_{2}$, respectivamente. Estes valores estão próximo do valores encontrado no experimento em condições de campo que variou de 8,65 a 13,01 e menores que os valores encontrados por Hernandez (1995), valores compreendidos entre 17,53 e 19,82, porém maiores que alguns valores obtidos por Ritschel et al. (1994) com valores variado de 5,42 a 6,49 em um experimento e 15,49 a 19,82 em outro experimento. Segundo estes autores aumento do intervalo de irrigação pode reduzir a eficiência do uso de água, evidenciando que aplicações de água menos frequentes podem aumentar as perdas por percolação e distribuição da água na zona radicular da cultura.

\section{5- Considerações finais}

A taxa de assimilação de $\mathrm{CO}_{2}$ aumentou tanto em função do PAR, quanto da concentração de $\mathrm{CO}_{2}$. $\mathrm{O}$ aumento da taxa de assimilação de $\mathrm{CO}_{2}$ ocorreu até atingir o ponto de saturação lumínica, que é mais elevado em ambiente com maior concentração de $\mathrm{CO}_{2}$, notadamente em plantas $\mathrm{C}_{3}$. O ponto de compensação de $\mathrm{CO}_{2}$ determinado para a cultura meloeiro foi de $68,8 \mu \mathrm{molCO} 2 \cdot \mathrm{mol}^{-1}$, compreendido fora do intervalo proposto para plantas $C_{3}$ por Bauer \& Martha $^{3}$ Salisbury \& Ross (1991). E o ponto de compensação luminoso encontrado para o meloeiro foi $33,1 \mu \mathrm{mol} \cdot \mathrm{m}^{-2} \cdot \mathrm{s}^{-1}$.

No experimento de campo a produtividade atingiu $38,6 \mathrm{t}^{-h^{-1}}$ e o peso médio do fruto foi de $1,11 \mathrm{~kg}$ com aplicação diária de $\mathrm{CO}_{2}$ via água de irrigação, enquanto que na ambiente protegido a produção foi de 28,7 t ha $\mathrm{ha}^{-1}$ e o fruto com peso médio de frutos de $0,875 \mathrm{~kg}$. A menor produção em ambiente protegido pode estar relacionada com a ocorrência de frentes frias coincidentes com os períodos de florescimento e frutificação.

${ }^{3}$ BAUER, A.; MARATHA, P. The CO2 compensation point of $\mathrm{C} 3$ plants - a re-examination. I. Interspecific variability. Zeitschrift für Pftanzenphysiologie. v.103, p.445-450, 1981. 
O meloeiro é uma planta exigente em temperaturas, sendo a temperatura ideal compreendida entre 25 e $32^{\circ} \mathrm{C}$. Temperatura média abaixo de $18^{\circ} \mathrm{C}$ dificulta a abertura das flores. Com temperatura mínima abaixo de $15^{\circ} \mathrm{C}$ o desenvolvimento da planta pode ser paralisado (Silva, 1982). Verificou-se (Tabela 10, Anexo) que após o dia 24/4 a temperatura mínima foi inferior a $15^{\circ} \mathrm{C}$, atingindo valores menores que $10^{\circ} \mathrm{C}$ entre os dias 26/5 e 27/5; 30/5 e 3/6; 7/6 e 11/6 de 1997. Em 24/4/1997 a cultura estava com 43 dias após a semeadura. $\mathrm{O}$ início do florescimento ocorreu em torno de 40 dias e a frutificação iniciou-se aproximadamente uma semana após o florescimento, conseqüentemente houve prejuízo na formação e desenvolvimento dos frutos. A temperatura média esteve abaixo de $18^{\circ} \mathrm{C}$ entre os dias $24 / 5$ e $17 / 6$ de 1997.

Diferenças de fertilidade de solo podem também ter influenciado a produção. A área do experimento de campo pode conter resíduos de fertilizantes de cultivos anteriores. $\mathrm{O}$ solo do ambiente protegido não foi cultivado anteriormente. Observou-se (Tabela 2) que as características químicas do solo do experimento de campo são mais apropriados ao desenvolvimento das culturas. Em ambos experimentos não foi aplicado micronutrientes e o experimento em ambiente protegido pode ter sido prejudicado devido à carência destes elementos nutritivos no solo.

Também, pode ter contribuído para menor produção em ambiente protegido a polinização, que foi manual, perdendo em eficiência quando comparada com a polinização realizada por abelhas.

O plástico utilizado na cobertura dos ambiente protegido apresentou um coeficiente de transparência igual a 73,3\%, impedindo a passagem de parte da radiação fotossinteticamente ativa. No período entre 16/4 à 26/6 de 1997 o somatório da radiação global dentro do ambiente protegido foi de 17930,$6 ; 25240,6 ; 27135,7$ e $21422,7 \mathrm{~J} \cdot \mathrm{m}^{-2} \cdot \mathrm{s}^{-1}$ às $10,11,12$ e 14 horas, respectivamente e a radiação global fora da estufa neste período foi de 28395,$3 ; 35134 ; 36807,4$ e $30272,2 \mathrm{~J}_{\mathrm{m}} \mathrm{m}^{-2} \cdot \mathrm{s}^{-1}$ às $10,11,12$ e 14 horas, respectivamente. Enquanto que durante o experimento de campo, período de 11/3 a 31/5 de 1996 , o somatório da radiação global média diária foi de $27675,7 \mathrm{~J} \cdot \mathrm{m}^{-2} \cdot \mathrm{s}^{-1}$. Menor valores de PAR acarretam menor fotossintese, conforme observado na Figura 10. 
Há indícios de que a aplicação de $\mathrm{CO}_{2}$ contribui para maior desenvolvimento da parte aérea das plantas, com formação de maior número de folhas, com área foliar individual maior. Também, resistência da cultura é maior em épocas de menores temperaturas. Em decorrência de frentes frias ocorridas durante a realização do experimento, observou-se visualmente que as plantas dos tratamentos com ausência de aplicação de $\mathrm{CO}_{2}$ murchavam quando ocorria queda de temperatura. No final do ciclo as plantas das parcelas sem aplicação de $\mathrm{CO}_{2}$ recuperam-se lentamente após ocorrência de frente fria, com paralisação de crescimento dos frutos, o que pode explicar o maior número de frutos e, conseqüentemente maior produção das parcelas com aplicação de $\mathrm{CO}_{2}$.

D'Andria et al. (1990) constataram aumento na produção de tomate devido à aplicação de $\mathrm{CO}_{2}$ em decorrência do aumento do tamanho de frutos e não maior número de frutos. Neste estudo encontrou-se frutos comerciais com peso médio maior $(1,11 \mathrm{~kg}$ e $0,88 \mathrm{~kg}$, com e sem aplicação $\mathrm{CO}_{2}$, em campo. Em ambiente protegido, o peso médio de frutos comerciais foi 0,875 e $0,800 \mathrm{~kg}$, com e sem aplicação de $\mathrm{CO}_{2}$, respectivamente). $\mathrm{O}$ número total de frutos foi maior (37000 com aplicação diária de $\mathrm{CO}_{2}$ contra $29000 \mathrm{sem}$ aplicação de $\mathrm{CO}_{2}$, no campo e 34500 e 30200, com e sem aplicação de $\mathrm{CO}_{2}$, respectivamente, em ambiente protegido) o que provavelmente ocorreu devido ao prolongamento do ciclo da cultura quando houve aplicação de $\mathrm{CO}_{2}$, discordando, portanto, dos resultado obtidos por D'Andria et al. (1990).

$\mathrm{O}$ teor médio de sólidos solúveis para o experimento de campo foi de $11,87^{\circ} \mathrm{Brix}$ contra $10,26^{\circ} \mathrm{Brix}$ obtido em ambiente protegido. Embora o teor de sólidos solúveis do melão produzido em condições de campo tenha sido $1,6^{\circ}$ Brix maior que o melão em ambiente protegido, ambos satisfazem as exigências dos mercados e são semelhantes aos valores médios em melões produzidos no Brasil, em torno de 10,5³rix (Gayet, 1994).

A acidez total foi $0,19 \%$ no experimento de campo e $0,20 \%$ em ambiente protegido e o pH 5,63 e 5,92, respectivamente em campo e ambiente protegido.

Comparando os resultados de análise foliar dos experimentos realizados em campo e em ambiente protegido pode-se notar que os valores de S, B, Fe e Mn foram maiores no experimento realizado em campo. As concentrações de S e Mn das folhas do 
meloeiro em ambiente protegido foram aproximadamente a metade das concentrações encontradas no experimento em campo. A concentração de ferro das folhas do experimento em campo ficou acima $760 \mathrm{mg} \cdot \mathrm{kg}^{-1}$, chegando a $1198,7 \mathrm{mg} \cdot \mathrm{kg}^{-1}$, enquanto em ambiente protegido os valores foram 161 e $248 \mathrm{mg}^{-1} \mathrm{~kg}^{-1}$ com e sem aplicação de dióxido de carbono, respectivamente. Trabalhando com algodão, aplicando $\mathrm{CO}_{2}$ via água de irrigação, Mauney \& Hendrix (1988) observaram redução do $\mathrm{pH}$, aumento da disponibilidade de fósforo e cálcio na solução do solo e maior absorção de zinco e manganês.

Considerando os resultados obtidos, necessita-se de estudos relacionados com doses, épocas de aplicação durante o ciclo da cultura, freqüências de aplicação e tempo de cada aplicação. Houve efeito significativo na taxa de assimilação no horário de aplicação (Tabela 7). Possivelmente, aumentar o período de aplicação de $\mathrm{CO}_{2}$ manteria a fotossíntese maior por um período mais longo.

O custo de produção para o melão determinado por Hernandez (1995) foi de US\$ 2.202,96. ha ${ }^{-1}$. O custo do quilograma do $\mathrm{CO}_{2}$ aplicado foi de US\$ 0,40 , na dose usada, significando um aumento no custo de produção da ordem de US $\$ 20,00 \cdot \mathrm{ha}^{-1}$. Portanto, a aplicação de $\mathrm{CO}_{2}$ representou aproximadamente $0,90 \%$ do custo de total de produção. $\mathrm{O}$ menor incremento de produção proporcionado pelo $\mathrm{CO}_{2}$ foi de 2,22 t.ha ${ }^{-1}$, quando comparou-se os tratamentos $\mathrm{T}_{4}$ e $\mathrm{T}_{6}$ (aplicação diária de $\mathrm{CO}_{2}$ e sem aplicação de $\mathrm{CO}_{2} \mathrm{em}$ solo coberto com plástico, em condições de campo). Este acréscimo de produção corresponde a um aumento de receita de US\$ $666,00 \cdot \mathrm{ha}^{-1}$. O maior incremento de produção foi 7,95 t.ha ${ }^{-1}$, comparando-se os tratamentos $T_{7}$ e $T_{9}$, o que representou um aumento de receita igual a US $\$ 2.385,00 . \mathrm{ha}^{-1}$. O confronto entre o aumento no custo de produção e o aumento na receita devida a aplicação de $\mathrm{CO}_{2}$, mostra a viabilidade da utilização desta prática para fins agrícolas. 


\section{5- CONCLUSÕES}

Tanto no experimento de campo como em ambiente protegido a aplicação de $\mathrm{CO}_{2}$ vai água de irrigação proporcionou aumento na produtividade total e comercial, no número e no peso de frutos do meloeiro, sem alteração de qualidade.

- As maiores produtividades de melão (38,6 e 37,1 tha $\left.{ }^{-1}\right)$ foram obtidas nos tratamentos com aplicação de dióxido de carbono via água de irrigação.

- Houve incremento da ordem de $70 \%$ na produtividade comercial com uso de proteção lateral e aplicação de $\mathrm{CO}_{2}$.

- A proteção lateral provocou aumento na produtividade de frutos comerciais em torno de $39,3 \%$.

- A frequência diária de aplicação de $\mathrm{CO}_{2}$ proporcionou maiores produtividades.

- Não houve diferenças entre os teores de nutrientes nas folhas do meloeiro ocasionada pela aplicação de dióxido de carbono através da água de irrigação, em condições de campo, exceto para o boro.

- A fotossíntese foi maior no tratamento com aplicação de $\mathrm{CO}_{2}$ quando medida no horário de aplicação do dióxido de carbono e igual nos demais horários.

- A eficiência do uso de água foi maior nos tratamentos com aplicação de $\mathrm{CO}_{2}$ via água de irrigação.

- A aplicação de $\mathrm{CO}_{2}$ via água de irrigação não afetou as características químicas dos frutos por um período de trinta dias de armazenamento. 
ANEXOS 
Tabela 9. Parâmetros climáticos durante o experimento realizado em campo.

\begin{tabular}{|c|c|c|c|c|c|c|c|c|}
\hline \multirow[t]{2}{*}{ Data } & \multicolumn{3}{|c|}{$\mathrm{T}_{\mathrm{ar}}\left({ }^{\circ} \mathrm{C}\right)$} & \multirow{2}{*}{$\begin{array}{l}\text { Evap } \\
(\mathrm{mm})\end{array}$} & \multirow{2}{*}{$\begin{array}{l}\text { UR } \\
(\%)\end{array}$} & \multirow{2}{*}{$\begin{array}{l}\text { Prec } \\
(\mathrm{mm})\end{array}$} & \multirow{2}{*}{$\begin{array}{c}\text { Rad Global } \\
\mathrm{J} \cdot \mathrm{m}^{-2} \cdot \mathrm{s}^{-1}\end{array}$} & \multirow{2}{*}{$\begin{array}{c}\text { Insolação } \\
\text { h.d } \mathrm{d}^{-1}\end{array}$} \\
\hline & $\mathrm{T}_{\mathrm{Med}}$ & $\mathrm{T}_{\mathrm{Max}}$ & $\mathrm{T}_{\mathrm{Min}}$ & & & & & \\
\hline $11 / 03 / 96$ & 22,60 & 29,00 & 16,20 & 5,62 & 74,00 & 0,00 & 478,94 & 7,70 \\
\hline $12 / 03 / 96$ & 24,30 & 29,40 & 19,20 & 3,64 & 91,00 & 7,30 & 301,32 & 2,20 \\
\hline $13 / 03 / 96$ & 23,70 & 30,30 & 17,10 & 4,06 & 85,00 & 0,00 & 447,23 & 8,60 \\
\hline $14 / 03 / 96$ & 25,50 & 32,00 & 19,00 & 3,79 & 87,00 & 10,90 & 363,70 & 7,10 \\
\hline $15 / 03 / 96$ & 24,75 & 29,10 & 20,40 & 4,73 & 88,00 & 7,60 & 312,95 & 2,80 \\
\hline $16 / 03 / 96$ & 25,40 & 31,40 & 19,40 & 5,42 & 86,00 & 12,70 & 472,60 & 8,80 \\
\hline $17 / 03 / 96$ & 23,45 & 27,90 & 19,00 & 3,06 & 88,00 & 0,40 & 307,67 & 4,40 \\
\hline $18 / 03 / 96$ & 25,55 & 31,60 & 19,50 & 5,35 & 80,00 & 0,00 & 425,02 & 7,00 \\
\hline 19/03/96 & 25,50 & 31,80 & 19,20 & 3,23 & 90,00 & 2,80 & 341,50 & 5,80 \\
\hline 20/03/96 & 24,80 & 29,00 & 20,60 & 3,52 & 87,00 & 1,90 & & 2,60 \\
\hline $21 / 03 / 97$ & 24,35 & 29,50 & 19,20 & 5,54 & 82,00 & 0,00 & 398,59 & 4,70 \\
\hline $22 / 03 / 96$ & 24,65 & 30,30 & 19,00 & 5,60 & 82,00 & 0,00 & 437,71 & 8,80 \\
\hline $23 / 03 / 96$ & 24,90 & 30,20 & 19,60 & 3,49 & 89,00 & 10,60 & 415,51 & 7,00 \\
\hline $24 / 03 / 96$ & 25,40 & 31,50 & 19,30 & 5,87 & 83,00 & 0,00 & 475,77 & 8,50 \\
\hline $25 / 03 / 96$ & 25,20 & 30,30 & 20,10 & 6,38 & 80,00 & 0,00 & 503,26 & 10,20 \\
\hline $26 / 03 / 96$ & 25,60 & 33,20 & 18,00 & 5,79 & 77,00 & 0,00 & 452,51 & 10,10 \\
\hline $27 / 03 / 96$ & 26,95 & 33,50 & 20,40 & 5,71 & 83,00 & 4,30 & 405,99 & 9,00 \\
\hline 28/03/96 & 25,35 & 31,60 & 19,10 & 4,80 & 82,00 & 0,00 & 430,31 & 8,20 \\
\hline
\end{tabular}


Continuação

\begin{tabular}{|c|c|c|c|c|c|c|c|c|}
\hline \multirow[t]{2}{*}{ Data } & \multicolumn{3}{|c|}{$\mathrm{T}_{\mathrm{ar}}\left({ }^{0} \mathrm{C}\right)$} & \multirow{2}{*}{$\begin{array}{l}\text { Evap } \\
(\mathrm{mm})\end{array}$} & \multirow{2}{*}{$\begin{array}{l}\text { UR } \\
(\%)\end{array}$} & \multirow{2}{*}{$\begin{array}{l}\text { Prec } \\
(\mathrm{mm})\end{array}$} & \multirow{2}{*}{$\begin{array}{l}\text { Rad Global } \\
\text { J.m } \mathrm{m}^{-2} \cdot \mathrm{s}^{-1}\end{array}$} & \multirow{2}{*}{$\begin{array}{c}\text { Insolação } \\
\text { h.d } \mathrm{d}^{-1}\end{array}$} \\
\hline & $T_{\text {Med }}$ & $\mathrm{T}_{\text {Max }}$ & $T_{\text {Min }}$ & & & & & \\
\hline 29/03/96 & 26,50 & 33,00 & 20,00 & 5,00 & 82,00 & 7,90 & 428,20 & 7,60 \\
\hline $30 / 03 / 96$ & 27,00 & 33,40 & 20,60 & 5,92 & 76,00 & 0,00 & 471,54 & 8,90 \\
\hline $31 / 03 / 96$ & 27,15 & 34,30 & 20,00 & 6,16 & 75,00 & 0,00 & 458,86 & 9,10 \\
\hline $01 / 04 / 96$ & 27,00 & 34,20 & 19,80 & 4,89 & 81,00 & 0,00 & 431,37 & 9,10 \\
\hline 02/04/96 & 26,80 & 33,40 & 20,20 & 4,85 & 81,00 & 0,00 & 389,08 & 6,60 \\
\hline 03/04/96 & 26,35 & 33,80 & 18,90 & 5,56 & 72,00 & 0,00 & 425,02 & 9,90 \\
\hline 04/04/96 & 25,65 & 32,10 & 19,20 & 6,92 & 76,00 & 0,00 & 437,71 & 10,00 \\
\hline 05/04/96 & 25,70 & 32,20 & 19,20 & 5,90 & 73,00 & 0,00 & 465,20 & 10,20 \\
\hline 06/04/96 & 25,35 & 32,30 & 18,40 & 4,84 & 79,00 & 0,00 & 433,48 & 8,80 \\
\hline 07/04/96 & 25,60 & 32,60 & 18,60 & 5,65 & 77,00 & 0,00 & & 9,20 \\
\hline 08/04/96 & 25,95 & 32,90 & 19,00 & 5,41 & 77,00 & 0,00 & 420,79 & 9,30 \\
\hline 09/04/96 & 25,55 & 32,60 & 18,50 & 4,68 & 80,00 & 0,00 & 412,34 & 9,50 \\
\hline $10 / 04 / 96$ & 25,75 & 33,20 & 18,30 & 5,17 & 77,00 & 0,00 & 415,51 & 8,00 \\
\hline $11 / 04 / 96$ & 22,45 & 25,00 & 19,90 & 2,69 & 92,00 & 0,00 & 135,33 & 0,00 \\
\hline $12 / 04 / 96$ & 22,30 & 24,70 & 19,90 & 2,04 & 91,00 & 0,20 & 151,19 & 0,00 \\
\hline $13 / 04 / 96$ & 24,25 & 28,90 & 19,60 & 3,30 & 84,00 & 0,10 & 331,98 & 5,90 \\
\hline $14 / 04 / 96$ & 25,15 & 31,00 & 19,30 & 4,32 & 84,00 & 0,90 & 401,76 & 8,20 \\
\hline $15 / 04 / 96$ & 25,10 & 30,80 & 19,40 & 5,28 & 80,00 & 0,20 & 393,31 & 8,30 \\
\hline
\end{tabular}


.. Continuação

\begin{tabular}{|c|c|c|c|c|c|c|c|c|}
\hline \multirow[t]{2}{*}{ Data } & \multicolumn{3}{|c|}{$\mathrm{T}_{\mathrm{ar}}\left({ }^{\circ} \mathrm{C}\right)$} & \multirow{2}{*}{$\begin{array}{l}\text { Evap } \\
(\mathrm{mm})\end{array}$} & \multirow{2}{*}{$\begin{array}{l}\text { UR } \\
(\%)\end{array}$} & \multirow{2}{*}{$\begin{array}{l}\text { Prec } \\
(\mathrm{mm})\end{array}$} & \multirow{2}{*}{$\begin{array}{l}\text { Rad Global } \\
\mathrm{J} \cdot \mathrm{m}^{-2} \cdot \mathrm{s}^{-1}\end{array}$} & \multirow{2}{*}{$\begin{array}{l}\text { Insolaçãc } \\
\text { h. } \mathrm{d}^{-1}\end{array}$} \\
\hline & $\mathrm{T}_{\mathrm{Med}}$ & $T_{\operatorname{Max}}$ & $T_{\text {Min }}$ & & & & & \\
\hline $16 / 04 / 96$ & 25,15 & 30,40 & 19,90 & 4,06 & 88,00 & 10,60 & 328,81 & 5,30 \\
\hline $17 / 04 / 96$ & 22,90 & 26,20 & 19,60 & 3,51 & 88,00 & 0,00 & 246,34 & 2,70 \\
\hline $18 / 04 / 96$ & 19,10 & 24,60 & 13,60 & 3,51 & 75,00 & 0,00 & & 8,90 \\
\hline $19 / 04 / 96$ & 17,25 & 25,10 & 9,40 & 7,91 & 76,00 & 0,00 & & 10,10 \\
\hline $20 / 04 / 96$ & 19,65 & 26,20 & 13,10 & 4,92 & 76,00 & 0,00 & & 10,30 \\
\hline $21 / 04 / 96$ & 19,70 & 27,50 & 11,90 & 4,26 & 73,00 & 0,00 & 478,94 & 9,70 \\
\hline $22 / 04 / 96$ & 19,80 & 28,20 & 11,40 & 4,32 & 73,00 & 0,00 & & 10,30 \\
\hline $23 / 04 / 96$ & 20,55 & 28,90 & 12,20 & 4,22 & 75,00 & 0,00 & 433,48 & 10,00 \\
\hline 24/04/96 & 20,65 & 29,40 & 11,90 & 4,60 & 74,00 & 0,00 & 436,65 & 10,30 \\
\hline $25 / 04 / 96$ & 22,05 & 30,60 & 13,50 & 4,56 & 67,00 & 0,00 & 444,05 & 10,50 \\
\hline $26 / 06 / 96$ & 21,20 & 27,00 & 15,40 & 6,44 & 79,00 & 0,00 & 333,04 & 7,00 \\
\hline $27 / 04 / 96$ & 20,65 & 25,90 & 15,40 & 4,62 & 74,00 & 0,00 & 347,84 & 6,10 \\
\hline $28 / 04 / 96$ & 22,00 & 28,80 & 15,20 & 4,96 & 75,00 & 0,00 & 428,20 & 9,30 \\
\hline 29/04/96 & 21,60 & 29,10 & 14,10 & 3,78 & 77,00 & 0,00 & 379,56 & 9,10 \\
\hline $30 / 04 / 96$ & 20,95 & 27,30 & 14,60 & 4,54 & 79,00 & 0,00 & 367,93 & 8,50 \\
\hline $01 / 05 / 96$ & 19,05 & 24,00 & 14,10 & 2,74 & 81,00 & 0,00 & 304,49 & 4,30 \\
\hline $02 / 05 / 96$ & 20,75 & 26,50 & 15,00 & 4,30 & 79,00 & 0,00 & 319,30 & 5,40 \\
\hline $03 / 05 / 96$ & 19,05 & 25,10 & 13,00 & 4,16 & 79,00 & 0,00 & 312,95 & 7,30 \\
\hline
\end{tabular}


Continuação

\begin{tabular}{|c|c|c|c|c|c|c|c|c|}
\hline \multirow[t]{2}{*}{ Data } & \multicolumn{3}{|c|}{$\mathrm{T}_{\text {ar }}\left({ }^{\circ} \mathrm{C}\right)$} & \multirow{2}{*}{$\begin{array}{l}\text { Evap } \\
(\mathrm{mm})\end{array}$} & \multirow{2}{*}{$\begin{array}{l}\text { UR } \\
(\%)\end{array}$} & \multirow{2}{*}{$\begin{array}{l}\text { Prec } \\
(\mathrm{mm})\end{array}$} & \multirow{2}{*}{$\begin{array}{l}\text { Rad Global } \\
\mathrm{J} \cdot \mathrm{m}^{-2} \cdot \mathrm{s}^{-1}\end{array}$} & \multirow{2}{*}{$\begin{array}{c}\text { Insolação } \\
h \cdot d^{-1}\end{array}$} \\
\hline & $\mathrm{T}_{\text {Med }}$ & $\mathrm{T}_{\mathrm{Max}}$ & $\mathrm{T}_{\mathrm{Min}}$ & & & & & \\
\hline $04 / 05 / 96$ & 19,85 & 28,10 & 11,60 & 4,24 & 76,00 & 0,00 & 423,97 & 9,80 \\
\hline 05/05/96 & 20,20 & 28,10 & 12,30 & 3,12 & 74,00 & 0,00 & 367,93 & 7,70 \\
\hline $06 / 05 / 96$ & 20,45 & 29,00 & 11,90 & 3,90 & 76,00 & 0,00 & 414,45 & 9,30 \\
\hline $07 / 05 / 96$ & 20,75 & 29,50 & 12,00 & 3,82 & 75,00 & 0,00 & 393,31 & 8,40 \\
\hline 08/05/96 & 21,75 & 30,30 & 13,20 & 2,80 & 71,00 & 0,00 & 376,39 & 9,30 \\
\hline 09/05/96 & 18,80 & 24,50 & 13,10 & 1,38 & 84,00 & 3,10 & 186,08 & 4,30 \\
\hline $10 / 05 / 96$ & 20,10 & 24,40 & 15,80 & 1,90 & 92,00 & 0,20 & 208,28 & 1,80 \\
\hline $11 / 05 / 96$ & 18,20 & 24,60 & 11,80 & 4,98 & 76,00 & 0,00 & 396,48 & 9,60 \\
\hline $12 / 05 / 96$ & 18,45 & 27,70 & 9,20 & 3,66 & 75,00 & 0,00 & 405,99 & 9,70 \\
\hline $13 / 05 / 96$ & 20,20 & 30,10 & 10,30 & 3,42 & 74,00 & 0,00 & 382,73 & 9,80 \\
\hline $14 / 05 / 96$ & 22,30 & 29,20 & 15,40 & 3,69 & 80,00 & 0,00 & 335,16 & 7,80 \\
\hline $15 / 05 / 96$ & 22,10 & 29,00 & 15,20 & 3,21 & 87,00 & 3,50 & 304,49 & 6,40 \\
\hline $16 / 05 / 96$ & 20,90 & 24,00 & 17,80 & 0,90 & 91,00 & 2,40 & 198,77 & 2,70 \\
\hline $17 / 05 / 96$ & 19,90 & 25,60 & 14,20 & 3,02 & 81,00 & 0,30 & 355,24 & 9,50 \\
\hline $18 / 05 / 96$ & 18,60 & 21,80 & 15,40 & 1,53 & 96,00 & 1,90 & 116,30 & 0,00 \\
\hline $19 / 05 / 96$ & 19,60 & 26,00 & 13,20 & 2,18 & 87,00 & 0,00 & 291,81 & 5,20 \\
\hline $20 / 05 / 96$ & 18,80 & 25,50 & 12,10 & 1,77 & 85,00 & 0,00 & 282,29 & 5,10 \\
\hline $21 / 05 / 96$ & 20,10 & 26,20 & 14,00 & 2,70 & 82,00 & 3,20 & 284,41 & 4,70 \\
\hline
\end{tabular}


Continuação

\begin{tabular}{|c|c|c|c|c|c|c|c|c|}
\hline \multirow[t]{2}{*}{ Data } & \multicolumn{3}{|c|}{$\mathrm{T}_{\mathrm{ar}}\left({ }^{\circ} \mathrm{C}\right)$} & \multirow{2}{*}{$\begin{array}{l}\text { Evap } \\
(\mathrm{mm})\end{array}$} & \multirow{2}{*}{$\begin{array}{l}\text { UR } \\
(\%)\end{array}$} & \multirow{2}{*}{$\begin{array}{l}\text { Prec } \\
(\mathrm{mm})\end{array}$} & \multirow{2}{*}{$\begin{array}{l}\text { Rad Global } \\
\mathrm{J} \cdot \mathrm{m}^{-2} \cdot \mathrm{s}^{-1}\end{array}$} & \multirow{2}{*}{$\begin{array}{c}\text { Insolação } \\
h . d^{-1}\end{array}$} \\
\hline & $\mathrm{T}_{\text {Med }}$ & $\mathrm{T}_{\mathrm{Max}}$ & $T_{\text {Min }}$ & & & & & \\
\hline $22 / 05 / 96$ & 20,15 & 24,50 & 15,80 & 1,00 & 94,00 & 0,90 & 173,39 & 3,30 \\
\hline $23 / 05 / 96$ & 21,20 & 26,60 & 15,80 & 2,19 & 81,00 & 0,80 & 316,12 & 6,30 \\
\hline $24 / 05 / 96$ & 19,10 & 23,00 & 15,20 & 4,93 & 81,00 & 0,00 & 260,09 & 5,90 \\
\hline $25 / 05 / 96$ & 16,85 & 23,80 & 9,90 & 3,30 & 73,00 & 0,00 & 342,56 & 7,60 \\
\hline $26 / 05 / 96$ & 18,25 & 25,10 & 11,40 & 3,14 & 76,00 & 0,00 & 352,07 & 8,70 \\
\hline $27 / 05 / 96$ & 18,25 & 26,30 & 10,20 & 2,83 & 78,00 & 0,00 & 485,86 & 9,70 \\
\hline $28 / 05 / 96$ & 17,60 & 25,30 & 9,90 & 2,80 & 77,00 & 0,00 & 329,87 & 6,90 \\
\hline $29 / 05 / 96$ & 17,00 & 24,90 & 9,10 & 1,79 & 78,00 & 0,00 & 338,33 & 7,80 \\
\hline $30 / 05 / 96$ & 17,30 & 26,20 & 8,40 & 0,54 & 83,00 & 0,00 & 279,12 & 5,60 \\
\hline $31 / 05 / 96$ & 19,25 & 28,50 & 10,00 & 4,50 & 71,00 & 0,00 & 339,38 & 9,20 \\
\hline
\end{tabular}




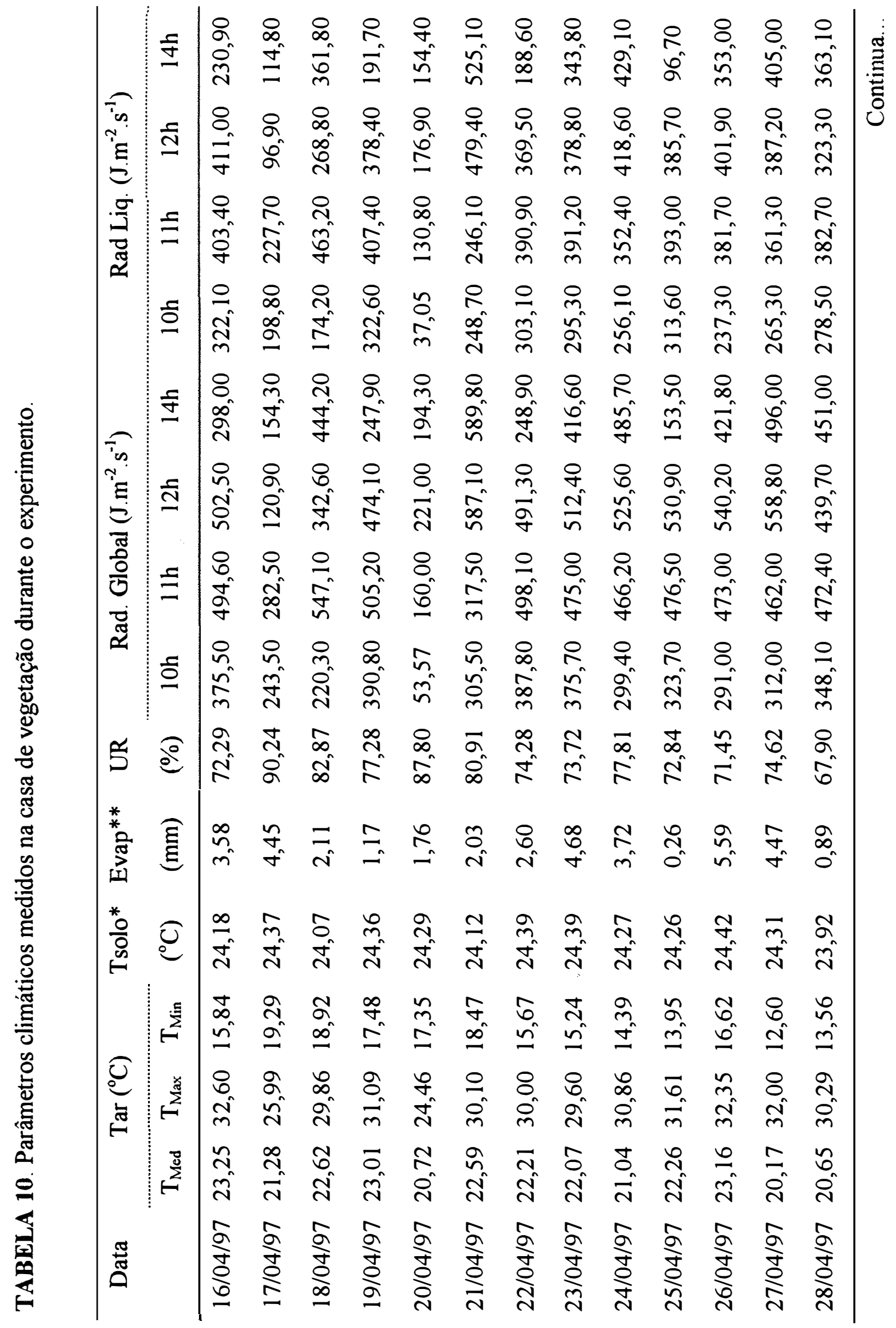




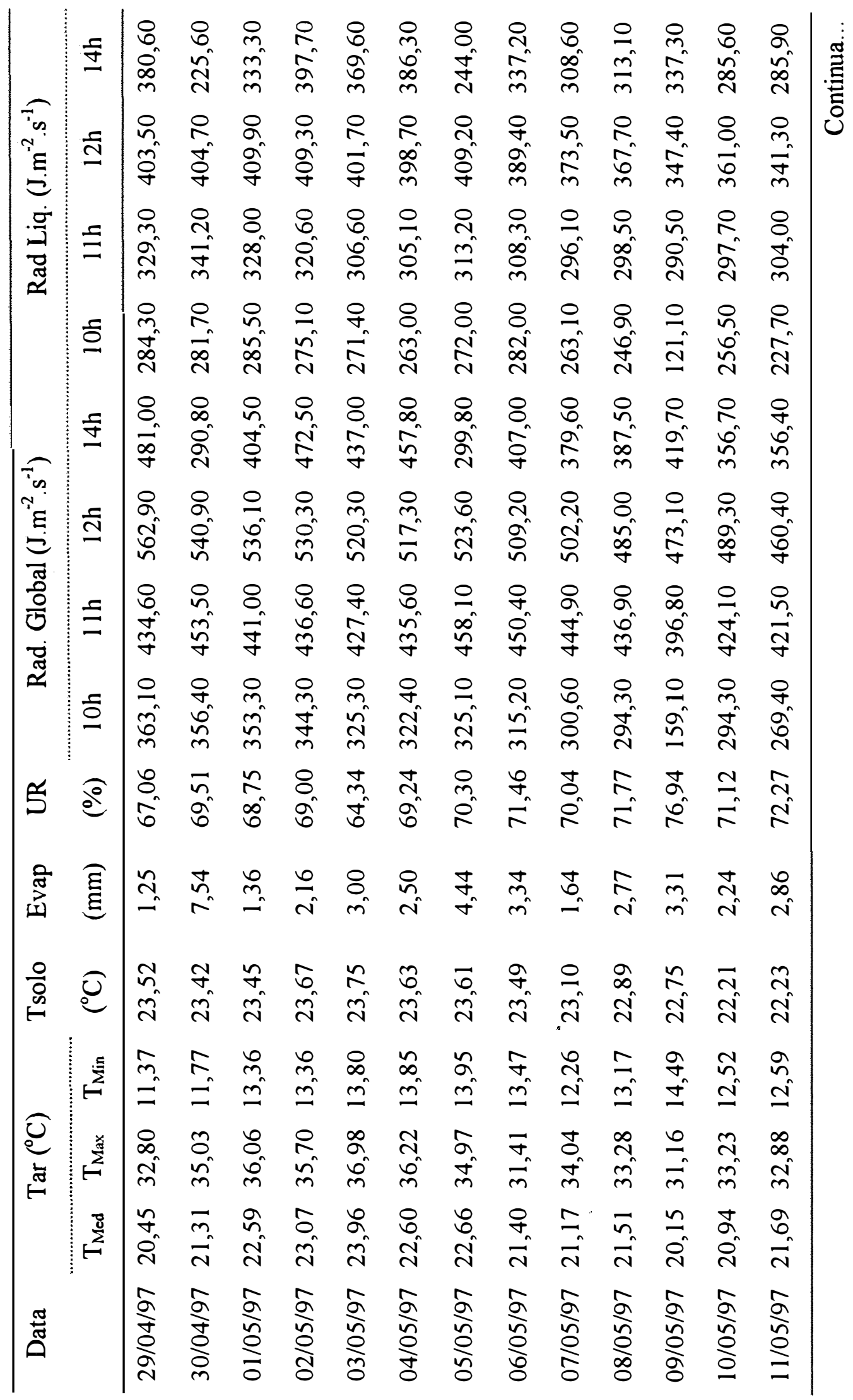




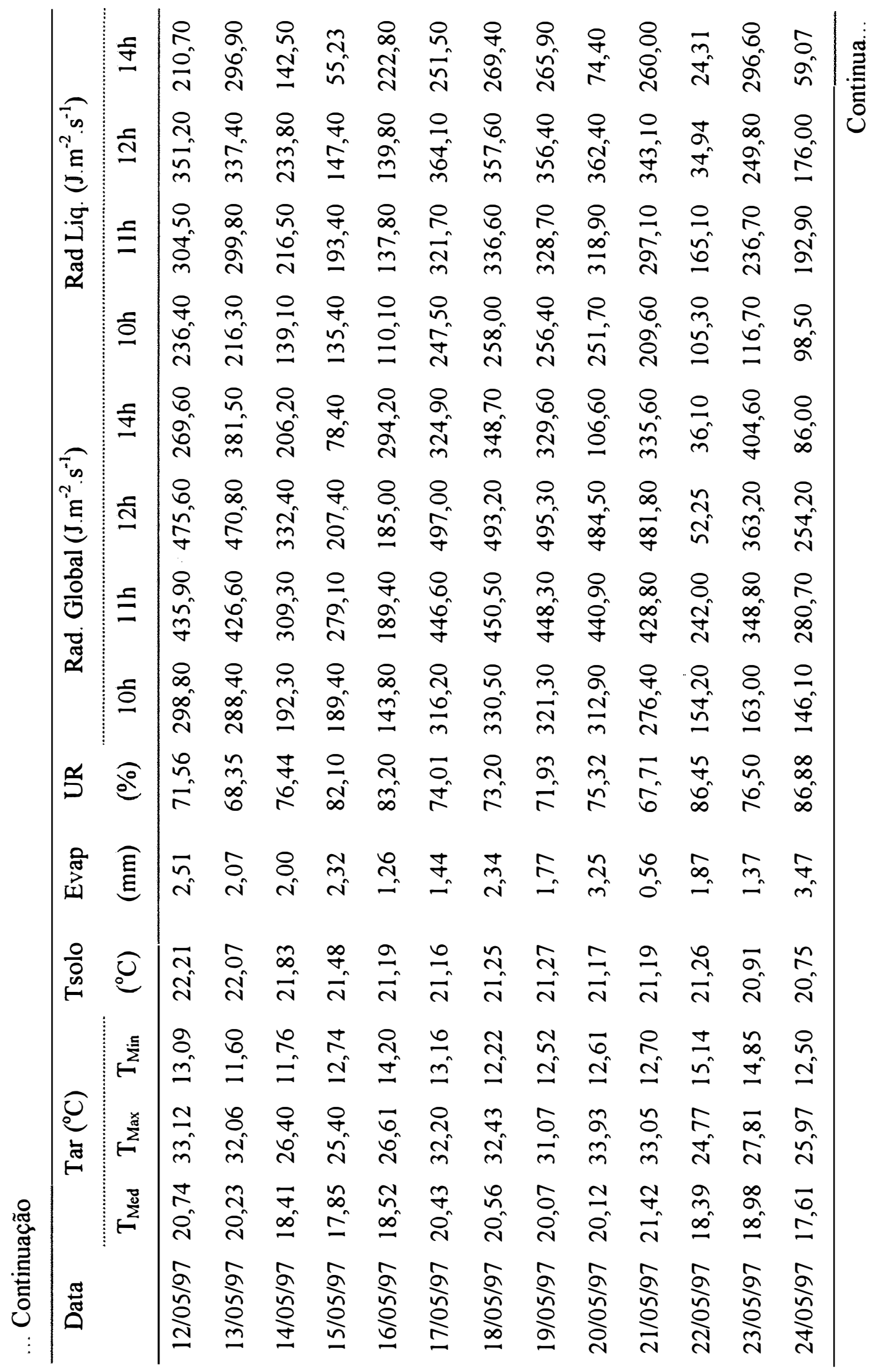




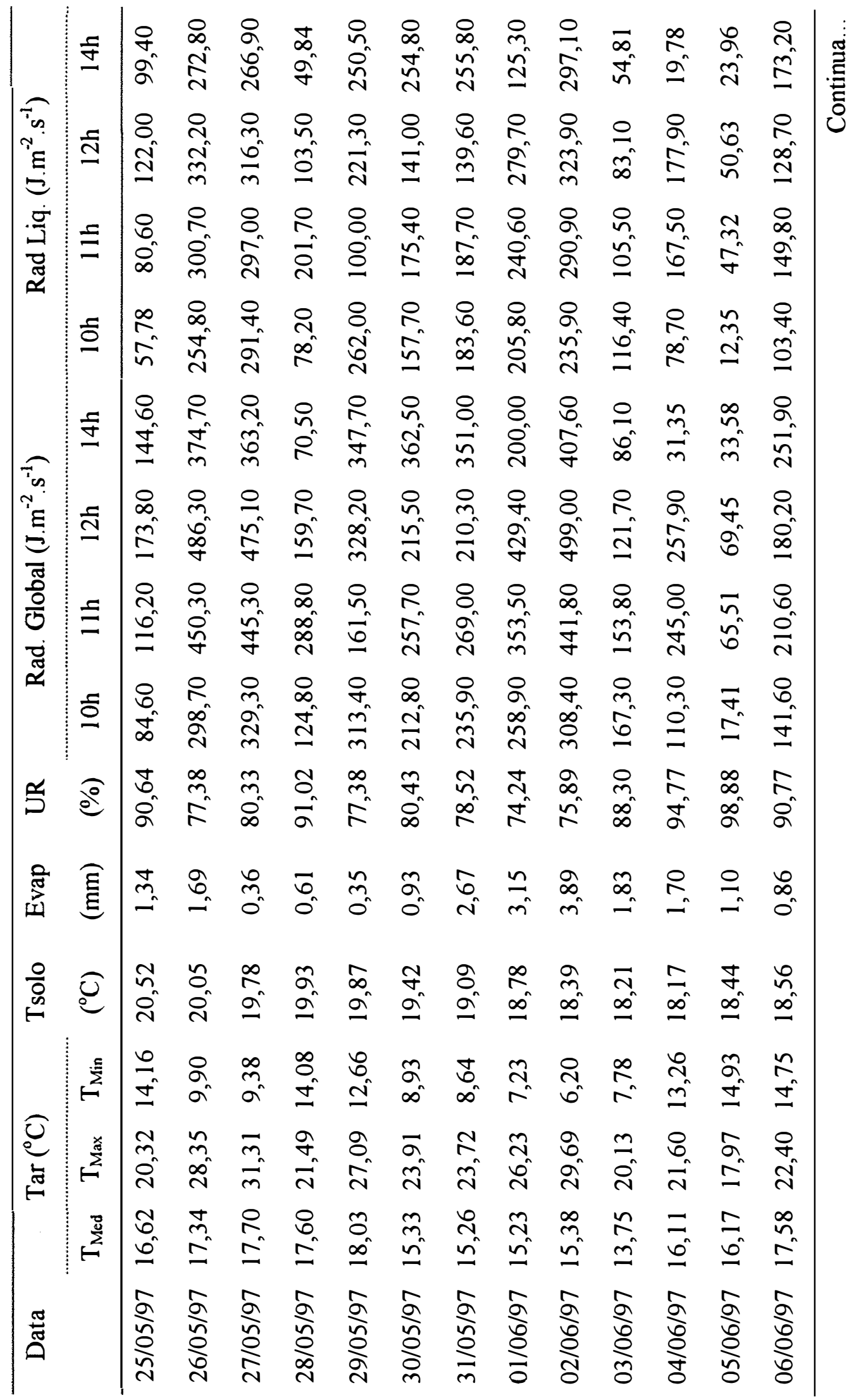




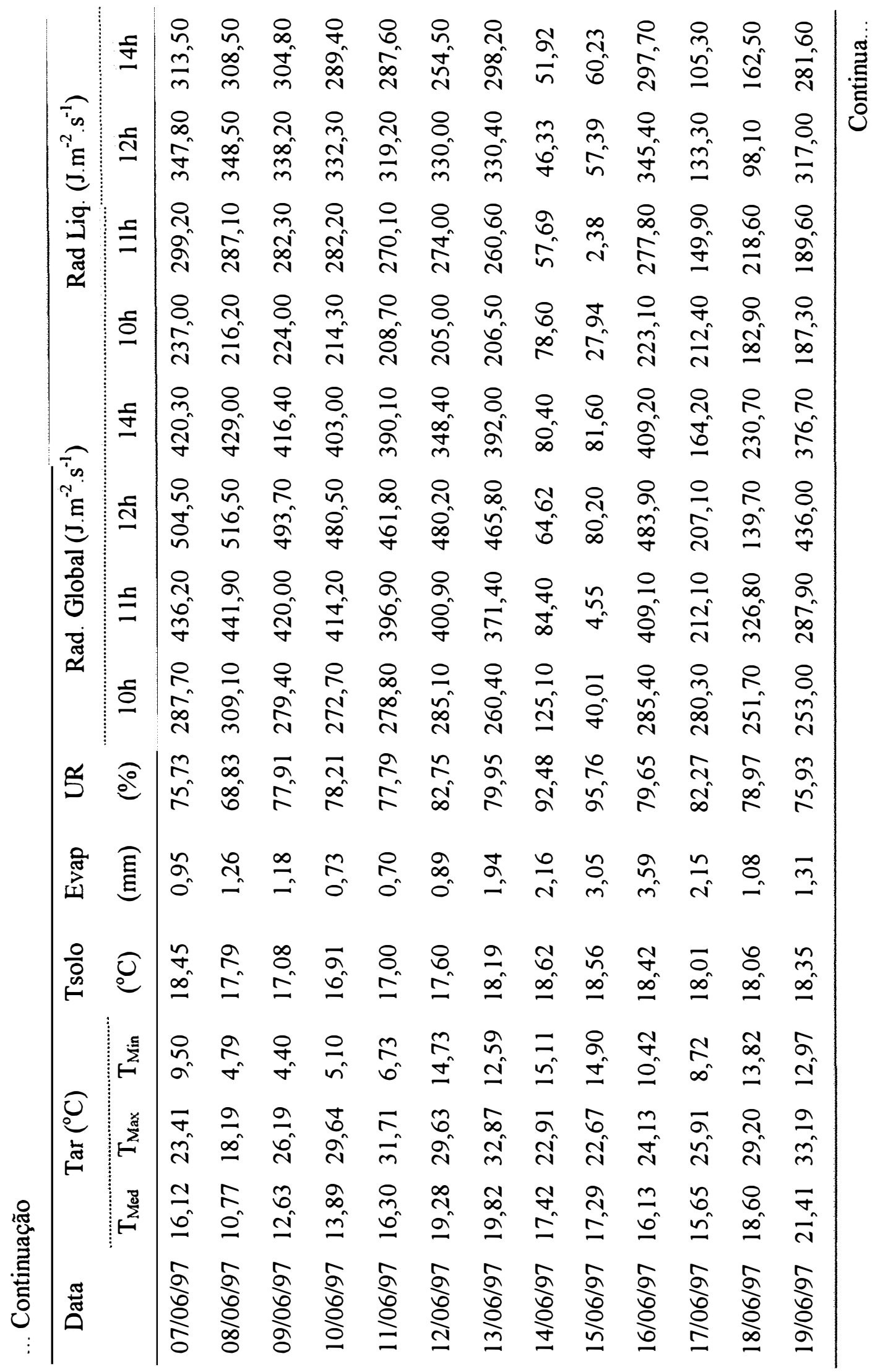




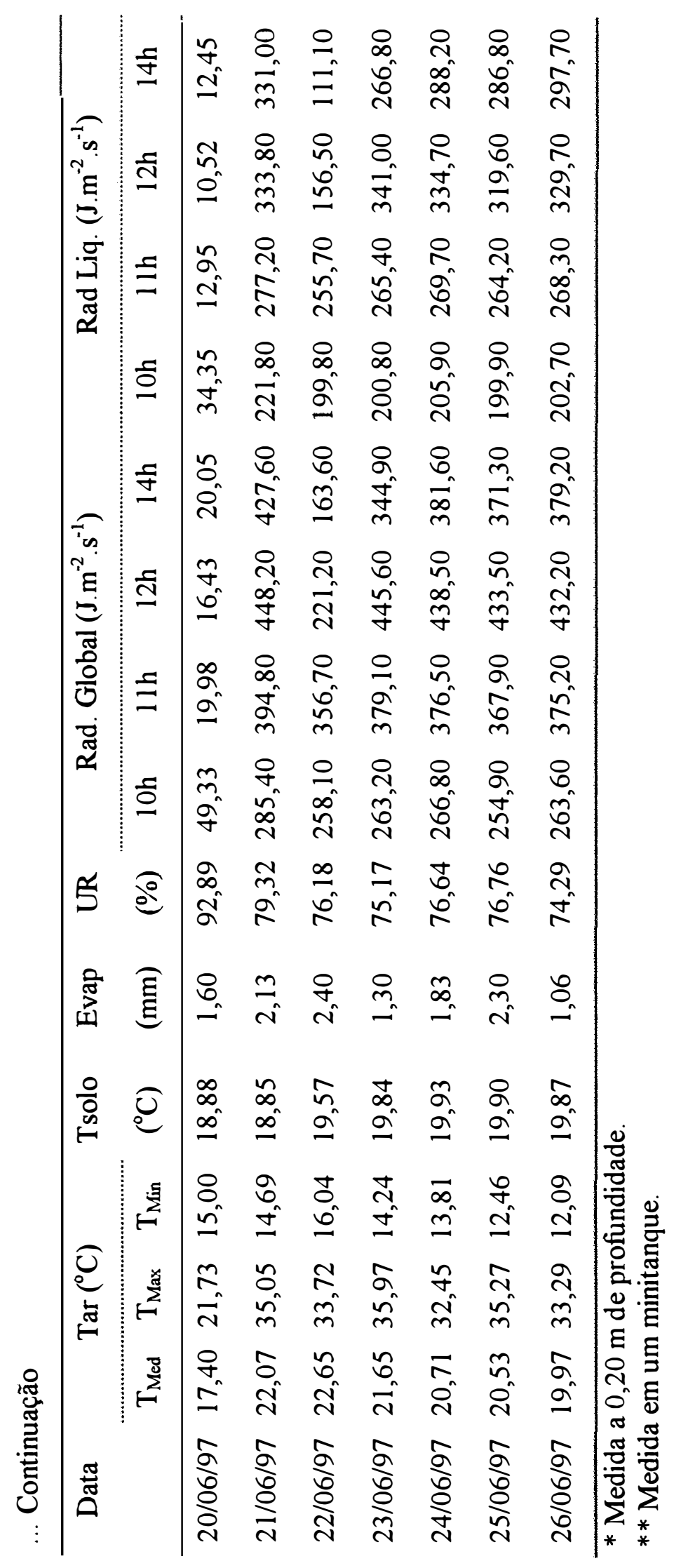




\section{REFERÊNCIAS BIBLIOGRÁFICAS}

ACOCK, B.; ACOCK, M. C.; PASTERNAK, D. Interactions of $\mathrm{CO}_{2}$ enrichment and temperature on carbohydrate production and accumulation in muskmelon leaves. Journal of the American for Horticultural Science, v. 115, n.4, p.525-529, 1990.

AHARONI, Y.; COPEL, A.; FALIK, E. Storing 'Galia' melons in a controlled atmosphere with ethylene absorbent. HortScience, v.28, n.7, p.725-727, 1993.

AIKEN, R. M.; JAWSON, M. D.; GRAHAMMER, K.; POLYMENOPOULOS, A. D. Positional, spatially correlated and random components of variability in carbon dioxide efflux. Journal of Environmental Quality, v.20, n.1, p.301-308, 1991.

ARAÚJO, J. P. Número de ramos e de frutos por planta e sua influência no tamanho dos frutos do meloeiro (Cucumis melo cv. Valenciano). Piracicaba, 1979. 63p. Dissertação (Mestrado) - Escola Superior de Agricultura "Luiz de Queiroz", Universidade de São Paulo.

ARTECA, R. N.; POOVAIAH, B. W. Absorption of ${ }^{14} \mathrm{CO}_{2}$ by potato roots and its subsequent translocation. Journal of the American Society for Horticutural Science, v. 107, n.3, p.398-401, 1982.

ARTECA, R. N.; POOVAIAH, B. W.; SMITH, O. E. Changes in carbon fixation, tuberization and growth induced by $\mathrm{CO}_{2}$ applications to the root zone of potato plants. Science, v.205, n.4412, p. 1279-1280, 1979.

AULENBACH, B. B.; WORTHINGTON, J. T. Sensory evaluation of muskmelons: is soluble solids content a good quality index. HortScience, v.9, n.2, p.136-137, 1974. 
BABENKO, Y. S.; TYRUGINA, G. I.; ORIGOREEV, E. F.; DALGIKH, L. M.; BORISOVA, T. I. Biological activity and physiological biochemical properties of phosphate dissolving bacteria. Microbiology, v.53, p.427-433, 1985.

BARON, J. J.; GORSKI, S. F. Response of eggplant to a root environment enriched with $\mathrm{CO}_{2}$. HortScience, v. 21, n.3, p.495-498, 1986.

BASILE, G.; ARIENZO, M.; ZENA, A. Soil nutrient mobility in response to irrigation with carbon dioxide enriched water. Communications in Soil Science and Plant Analysis, v.24, n.11/12, p.1183-1195, 1993.

BATTIKHI, A. M.; HILL, R. W. Irrigation scheduling and cantaloupe yield model for the Jordan Valley. Agricultural Water Management, v.15, n.2, p. 177-187, 1988.

BEGG, J. E.; TURNER, N. C. Crop water deficits. Advances in Agronomy, v.28, p.161-217, 1976.

BELFORT, C. C. Acumulação de matéria seca e recrutamento de nutrientes em melão (Cucumis melo L. cv. Valenciano Amarelo CAC) cultivado em latossolo vermelho amarelo em Presidente Wenceslau - SP. Piracicaba, 1985. 72p. Tese (Doutorado) Escola Superior de Agricultura "Luiz de Queiroz", Universidade de São Paulo.

BELFORT, C. C.; HAAG, H. P.; MATSUMOTO, T.; CARMELlO, Q. A. C.; SANTOS, J. W. C. Nutrição mineral de hortaliças. LXX. Acumulação de matéria seca e recrutamento de macronutrientes pelo melão (Cucumis melo $\mathrm{L}$. cv. Valenciano Amarelo CAC). Anais da Escola Superior de Agricultura "Luiz de Queiroz", v.43, p.159-218, 1986.

BHELLA, H. S. Muskmelon growth, yield, and nutrition as influenced by planting method and trickle irrigation. Journal of the American Society for Horticultural Science, v.110, n.6, p.793-796, 1985.

BHELLA, H. S.; WILCOX, G. E. Yield and composition of muskmelon as influenced by preplanting and trickle applied nitrogen. HortScience, v.21, n.1, p.86-88, 1986. 
BHELLA, H. S.; WILCOX, G. E. Lime and nitrogen influence soil acidity, nutritional status, vegetative growth, and yield of muskmelon. Journal of the American Society for Horticultural Science, v.11, n.4, p.606-610, 1989.

BLEINROTH, E. W. Determinação do ponto de colheita. In: GORGATTI NETTO, A.; GAYET, J. P.; BLEINROTh, E. W.; MATALlO, M.; GARCiA, E. E. C.; GARCIA, A. E.; ARDITO, E. F. G.; BORDIN, M. R. Melão para exportação: procedimentos de colheita e pós-colheita. Brasília: Embrapa, SPI, 1994. cap.2, p.1121. (FRUPEX. Publicações Técnica, 6).

BOSLAND, J. M.; HUGHES, D. L.; YAMAGUCHI, M. Effects of glyphosine and triacontanol on growth, yield, and soluble solids content of 'PMR 45' muskmelon. HortScience, v.14, n.6, p.729-730, 1979.

BUZETTI, S.; HERNANDEZ, F. B. T.; SÁ, M. S.; SUZUKI, M. A. Influência da adubação nitrogenada e potássica na eficiência do uso da água e na qualidade de frutos de melão. Scientia Agrícola, v.50, n.2, p.419-426, 1993.

CASALI, V. W. D.; SATURNINO, H. M.; PEDROSO, J. F. Botânica e origem das cucurbitáceas. Informe Agropecuário, v.8, n.15, p.15-18, 1982.

CASELLA, E.; SOUSSANA, J. F.; LOISEAU, P. Long-term effects of $\mathrm{CO}_{2}$ enrichment and temperature increase on a temperate grass sward. I. Productivity and water use. Plant and Soil, v. 187, n. 1, p.83-99, 1996.

CHMORA, S. N.; MOKRONOSOV, A. T. The global increase of $\mathrm{CO}_{2}$ in atmosphere: adaptive strategies in plants. Russian Journal of Plant Physiology, v.41, n.5, p. 768-778, 1994.

CHOUDHURY, E. N.; FARIA, C. M. B. Influência da vermiculita sobre a produção de melão e influência de irrigação no Trópico Semi-Árido do Nordeste. Petrolina:Embrapa, CPATSA, 1982. 20p. (Embrapa-CPATSA. Boletim de Pesquisa, 18). 
COMPANHIA DE DESENVOLVIMENTO DO VALE DO SÃO FRANCISCO Frutas brasileiras: exportação. Brasília, 1989, 352p.

CONROY, J. P. Influence of elevated atmospheric $\mathrm{CO}_{2}$ concentrations on plant nutrition. Australian Journal of Botany, v.40, n.4/5, p. 445-456, 1992.

COOKER, R. T.; SCHUBERT, K. R. Carbon dioxide fixation in soybean roots and nodules: I. Characterization and comparison with $\mathrm{N}_{2}$ fixation and comparison of xylem exudate during early nodule development. Plant Physiology, v.67, n.4, p.691$696,1981$.

COSTA, J. E. S. Análise físico-química do melão produzido em condições de casa de vegetação e irrigado pelos sistemas de jato-pulsante e gotejamento. Jaboticabal, 1987. 65p. Monografia (Graduação) - Faculdade de Ciências Agrárias e Veterinária, Universidade Estadual Paulista "Julio de Mesquita Filho".

CURE, J. D.; ACOCK, B. Crop responses to carbon dioxide doubling: a literature survey. Agricultural Forest and Meteorology, v.38, n. 1/3, p.127-145, 1986.

CURTIS, P. S.; BALDUMAN, L. M.; DRAKE, B. G.; WHIGHAM, D. F. Elevated atmospheric $\mathrm{CO}_{2}$ effects on belowground processes in $\mathrm{C}_{3}$ and $\mathrm{C}_{4}$ stuarine marsh communities. Ecology, v.71, n. 5, p. 2001-2006, 1990.

D'ANDRIA, R.; NOVERO, R.; SMITH, D. H. Drip irrigation of tomato using carbonated water and mulch in Colorado. Acta Horticulturae, v.278, p.179-185, 1990.

DAVIS, G. N.; MEINERT, V. G. H. The effect of plant spacing and fruit pruning on the fruits of PMR 45, Cantaloupe. Journal of American Society for Horticultural Science, v.87, n.2, p.299-302, 1965.

DAVIS Jr., R. M.; SCHWEERS, V. H. Associations between physical soil properties and soluble solids in cantaloupes. Journal of the American Society for Horticultural Science, v.96, n.2, p.213-217, 1971. 
DOORENBOS, J.; KASSAM, A. H. Efectos del agua sobre el rendimiento de los cultivos. Roma:FAO, 1988. 212p. (FAO. Boletin, 33).

DOORENBOS, J.; PRUIT, W. O. Las necesidades de agua de los cultivos. Roma:FAO, 1976. 194p. (FAO. Boletim, 24).

DUSI, A. N. Melão para exportação: aspectos técnicos da produção. Brasília: DENACOOP/FRUPEX, 1992. 32p. (DENACOOP. Série Publicações Técnicas, 1).

ELLS, J. E.; KROSE, E. G.; MESAY, E. Scheduling irrigation for cucumbers. Horticultural Science, v. 24, n.3, p.448-452, 1989.

ERMLAND JUNIOR, F. K. V. Efeito do cultivo em casa de vegetação com cobertura de polietileno sobre a qualidade tecnológica e conservação pós-colheita de melão (Cucumis melo L.) cv. Valeciano Amarelo CAC, com uso de irrigação por jatopulsante. Jaboticabal, 1986. 46p. Monografia (Graduação) - Faculdade de Ciências Agrárias e Veterinária, Universidade Estadual Paulista "Julio de Mesquita Filho".

FAQUHAR, G. D.; DUBLE, D. R.; RASCHKE, K. Gain of the feedback loop involving carbon dioxide and stomata, theory and measurement. Plant Physiology, v.62, n.3, p.406-412, 1978.

FERREIRA, F. A.; PEDROSA, J. F.; ALVARENGA, M. A. R. Melão: cultivares e métodos culturais. Informe Agropecuário, v. 8, n.85, p. 26-28, 1982.

FILGUEIRA, F. A. R. Manual de olericultura: cultura e comercialização de hortaliças. 2.ed. São Paulo:Agronômica Ceres, 1981. v.1,338p.

FINN, G. A.; BRUN, B. W. Effect of atmospheric $\mathrm{CO}_{2}$ enrichment on growth, nonstructural content, and root nodule activity in soybean. Plant Physiology, v.69, n.2, p.327-331, 1982.

FISCHER, M.; MATTHIES, D.; SCHMID, B. Responses of rare calcareous grassland plants to elevated $\mathrm{CO}_{2}$ : a field experiment with Gentianella germanica and Gentina cruciata. Journal of Ecology, v.85, n.5, p.681-691, 1997. 
FLOCKER, W. J.; LINGLE, J. G.; DAVIS, R. M.; MILLER, R. J. Influence of irrigation and nitrogen fertilization on yield, quality, and size of Cantaloupes. Proceedings of the American Society for Horticultural Science, v.86, p.424-432, 1965.

FORNEY, C. F. Ripening and solar exposure alter polar lipid fatty acid composition of 'Honey Dew' muskmelon. HortScience, v.25, n.10, p.1262-1264, 1990.

FOSTER, R. E.; GENTRY, J. P.; BESEY, P. M.; HARRIOTT, A. L. Mechanical stress and muskmelon fruit quality. HortScience, v. 14, n.1, p.25-26, 1979.

FUENTES, $\mathrm{H}$. de Consideraciones acerca de la producción y tratamiento de semillas de melon. In: SEMINÁRIO DE OLERICULTURA, 15., Viçosa. 1988. Anais. Viçosa:UFV, 1988. p. 58-73.

GAO, Q.; ZHANG, X. A simulation study of responses of the Northeast China transact to elevated $\mathrm{CO}_{2}$ and climate change. Ecological Applications, v.7, n.2, p.470-483, 1997.

GAYET, J. P. Características das frutas de exportação. In: GORGATTI NETTO, A.; GAYET, J. P.; BLEINROTH, E. W.; MATALLO, M.; GARCIA, E. E. C.; GARCIA, A. E.; ARDITO, E. F. G.; BORDIN, M. R. Melão para exportação: procedimentos de colheita e pós-colheita. Brasília: Embrapa, SPI, 1994. cap.1, p.910. (FRUPEX. Publicações Técnica, 6).

GHANNOUM, O.; CAEMMERER, S. V.; BARLOW, E. W. R.; CONROY, J. P. The effect of $\mathrm{CO}_{2}$ enrichment and irradiance on the growth, morphology and gas exchange of a $\mathrm{C}_{3}$ (Panicum loxum) and a $\mathrm{C}_{4}$ (Panicum antidotade) grass. Australian Journal of Plant Physiology, v.24, n.2, p.227-237, 1997.

GOLDBERG, D.; GORNAT, B.; RIMON, D. Drip irrigation: principles, design and agricultural practices. Kfar Shumaryahu:Drip Irrigation Scientific Publ., 1976. 296p.

GOLDBERG, D.; SHMUELI, M. Drip irrigation - a method used under arid and desert conditions of high water and soil salinity. Transactions of the ASAE, v.13, n.1, p.38-41, 1970. 
GONÇALVES, F. C. Armazenamento de melão "Piele de Sapo" sob condições ambiente. Mossoró, 1994. 42p. Monografia (Graduação) - Escola Superior de Agricultura de Mossoró.

GUIMARÃES, J. R. Determinação e especiação de carbono inorgânico em águas naturais e atmosfera por análise em fluxo. Campinas, 1995. 99p. Tese (Doutorado) Instituto de Química, Universidade Estadual de Campinas.

GUINN, G. Abscission of cotton floral buds and bolls as influenced by factors affecting photosynthesis and respiration. Crop Science, v.14, n.2, p.291-293, 1974.

HAM, J. M.; OWENSBY, C. E.; COYNE, P.;BREMER, D. J. Fluxes of $\mathrm{CO}_{2}$ and water vapor from a prairie ecosystem exposed to ambient and elevated atmospheric $\mathrm{CO}_{2}$. Agricultural Forest and Meteorology, v.77, n. 1/2, p.73-93, 1995.

HAVELY, I.; BOAZ, M.; ZOHAR, Y.; SHANI, M.; DAN, H. Trickle irrigation. Rome:FAO, 1973. 153p. (FAO: Irrigation and Drainage Paper, 14).

HERNANDEZ , F. B. T. Efeitos da supressão hídrica nos aspectos produtivos e qualitativos da cultura do melão. Piracicaba, 1995. 75p. Tese (Doutorado) - Escola Superior de Agricultura "Luiz de Queiroz", Universidade de São Paulo.

HUGES, D. L.; YAMAGUCHI, M. I. Identification and distribution of some carbohydrates in the muskmelon plant. HortScience, v. 18, n.5, p.739-740, 1983.

IDSO, K. E.; IDSO S. B. Plant responses to atmospheric $\mathrm{CO}_{2}$ enrichment in the face of environmental constraints: a review of the past 10 years' research. Agricultural Forest and Meteorology, v.69, n.3/4, p.153-203, 1994.

IDSO, S. B.; BRAZEL, A. J. Rising atmospheric carbon dioxide concentrations may increase streamflow. Nature, v.312, n.5989, p.51-53, 1984.

INSTITUTO ADOLFO LUTZ. Normas analíticas do Instituto Adolfo Luzt: métodos químicos e fisicos para análise de alimentos. 3.ed. São Paulo: Secretaria da Saúde do Estado de São Paulo, 1985. v.1, 533p. 
JURIK, T. W.; WEBER, J. A.; GATES, D. M. Short-term effect of $\mathrm{CO}_{2}$ on gas exchange of leaves of Bogtooth Aspen (Popolus grandidentata) in the field. Plant Physiology, v.75, n.4, p. 1022-1025, 1984.

KEELING, C. D.; WHORF, T P.; PFLIT, J. V. D. Interannual extremes in the rate of rise of atmospheric carbon dioxide since 1980. Nature, v.375, n.6533, p.666-670, 1995.

KIMBALL, B. A. Carbon dioxide and agricultural yield: an assemblage and analysis of 430 prior observation. Agronomy Journal, v.75, n.5, p.779-788, 1983.

KIMBALL, B. A.; IDSO, S. B. Increase atmospheric $\mathrm{CO}_{2}$ : effects on crop yield, water use, and climate. Agricultural Water Management, v.7, n.1, p. 55-73, 1983.

KIMBALL, B. A.; LaMORTE, R. L.; SEAY, R. S.; PINTER, P. J.; ROKEY, R. R.; HUNSAKER, D. J.; DUGAS. W. A.; HEUER, M. L.; MAUNEY, J. R.; HENDREY, G. R.; LEWIN, K. F.; NAGY, J. Effects of free air $\mathrm{CO}_{2}$ enrichment on energy balance and evapotranspiration of cotton. Agricultural Forest and Meteorology, v.70, n.1/4, p.259-278, 1994.

KÖRNER, C.; WÜRTH, M. A simple method for testing leaf responses of tall tropical forest trees to elevated $\mathrm{CO}_{2}$. Oecologia, v. 107, n. 4, p.421-425, 1996.

LARCHER, W. Physiological plant ecology. 3.ed. New York:Springer-Verlag, 1995. $505 p$.

LESTER, G.; SHELLIE K. C. Postharvest sensory and physicochemical attributes of Honey Dew melon fruits. HortScience, v.27, n.9, p.1012-1014, 1992.

LONG, S. P. Modification of the response of photosynthetic productivity to rising temperature by atmospheric $\mathrm{CO}_{2}$ concentration: has its importance been underestimated. Plant, Cell and Environment, v. 14, p.729-739, 1991.

LUO, Y.; FIELD, C. B.; MOONEY H. A. Producting responses of photosynthesis and root fraction to elevated $\mathrm{CO}_{2}$ : interactions among carbon, nitrogen, and growth. Plant, Cell and Environment, v. 17, n.11, p.1195-1204, 1994. 
LUO, Y.; JACKSON. R. B.; FIELD, C. B. Elevated $\mathrm{CO}_{2}$ increase belowground respiration in California grasslands. Oecologia, v.108, n.1, p.130-137, 1996.

MACGRILLIVRAI, J. H. Effect of irrigation on the production of cantaloupes. Proceedings of the American Society for Horticultural Science, v. 57, p. 266-272, 1951.

MALAVOlTA, E. ; VITTI, G. C.; OLIVEIRA, S. A. Avaliação do estado nutricional das plantas. Piracicaba:Associação Brasileira para a Pesquisa do Potássio e do Fosfato, 1989. 201p.

MAROUELLI, W. A.; SILVA, H. R. da; SILVA, W. L. C. Manejo de irrigação em hortaliças. Brasília:Embrapa, CNPH, 1989. 12p. (Embrapa-CNPH. Circular Técnica, 2).

MAUNEY, J. R.; HENDRIX, D. L. Responses of glasshouse grown cotton to irrigation with carbon dioxide-saturated water. Crop Science, v.28, n.5, p.835-838, 1988.

McDERMITT, D. K.; NORMAN, J. M.; DAVIS, J. T.; BALL, T. J.; ARKEBAUER, T. J.; WELLES, J. M.; ROEMER, S. R. $\mathrm{CO}_{2}$ response curves can be measured with a field-portable closed-loop photosynthesis system. Annals Sciences Foresters, v.46, p.416-420, 1989.

MEDEIROS, J. F. de; PEREIRA, F. A. de C.; FOLEGATTI, M. V.; PEREIRA, A. R.; VILLA NOVA, N. A. Comparação entre evaporação em tanque classe A padrão e em minitanque, instalados em estufa e estação meteorológica. In: CONGRESSO BRASILEIRO DE AGROMETEOROLOGIA, 10., Piracicaba. 1997. Anais. Piracicaba:ESALQ, 1997. p.228-230.

MENDLINGER, S. Effect of increasing plant density and salinity on yield and fruit quality in muskmelon. Scientia Horticulturae, v.57, n.1/2, p.41-49, 1994.

MENEZES, J. B. Qualidade pós-colheita de melão tipo galia durante a maturação e o armazenamento. Lavras, 1996. 137p. Tese (Doutorado) - Universidade Federal de Lavras. 
MENEZES, J. B.; CHITARRA, A. B.; CHITARRA, M. I. F.; CARVALHO, H. A. de Caracterização pós-colheita do melão amarelo "Agroflora 646". Horticultura Brasileira, v.13, n.2, p.150-153, 1995.

MICCOLIS, V.; SALTVEIT Jr., M. E. Morphological and physiological changes during fruit growth and maturation of seven melon cultivars. Journal of the American Society for Horticultural Science, v. 116, n. 6, p. 1025-1029, 1991.

MILLER R. J.; ROLSTON, D. E.; RAUSCHOKOLB, R. S.; WOLFE, D. W. Labeled nitrogen uptake by drip-irrigated tomatoes. Agronomy Journal, v.73, n.2, p.265270, 1981.

MITCHELL, J. F. B.; JOHNS, F. C.; GREGORY, J. M.; TETT, S. F. B. Climate response to increasing levels of greenhouse gases and sulphate aerosols. Nature. v. 376, n.6540, p.501-504, 1995.

MIZRACH, A.; GALILI, N.; TEITEL, D. C.; ROSENHOUSE, G. Ultrasonic evaluation of some ripening parameters of autumn and winter-grown 'Galia' melons. Scientia Horticulturae, v. 56, n.4, p.291-297, 1994.

MOORE, P. D. Potential for irrigation with carbon dioxide. Acta Horticulturae, v. 278, p.171-178, 1990.

MOORE, P. D. How do plants cope when they live in the shade? Nature, v.349, n.6304, p.22, 1991.

MORISON, J. I. L. Sensitivity of stomata and water use efficiency to high $\mathrm{CO}_{2}$. Plant, Cell and Environment, v.8, p.467-474, 1985.

MORISON, J. I. L.; GIFFORD, R. M. Plant growth and water use with limited water supply in high $\mathrm{CO}_{2}$ concentrations. I. Leaf area, water use and transpiration. Australian Journal of Plant Physiology, v.11, n.5, p.361-374, 1984. 
MUDRIK, V. A.; ROMANOVA, A. K.; IVANOV, B. N.; NOVICHKOVA, N. S.; POLYAKOVA, V. A. Effect of increased $\mathrm{CO}_{2}$ concentration on growth, photosynthesis, and composition of Pisum sativum L. plant. Russian Journal of Plant Physiology, v.44, n.2, p.165-171, 1997.

NAGAI, H. Instruções agrícolas para o Estado de São Paulo: melão. Campinas:IAC, 1987. 145p. (IAC. Boletim, 200).

NORBY, R. J.; O'NEIL E. G.; LUXMOORE, R. J. Effects of atmospheric $\mathrm{CO}_{2}$ enrichment on the growth and mineral nutrition of Quercus alba seedlings in nutrient-poor soil. Plant Physiology, v.82, n. 1, p.83-89, 1986.

NORBY, R. J.; GUNDERSON, C. A.; WULLSCHLEGER, S. D.; O’NEIL, E. G.; MCCRACKEN, M .K. Productivity and compensatory responses of yellow-poplar trees in elevated $\mathrm{CO}_{2}$. Nature, v.357, n.6376, p.322-324, 1992.

OMETTO, J. C. Registros e estimativas de parâmetros meteorológicos da região de Piracicaba, SP. Piracicaba:FEALQ, 1989. 76p.

PINTO, J. M.; SOARES, J. M.; PEREIRA, J. R.; CHOUDHURY, E. N.; CHOUDHURY, M. M. Efeitos de períodos e de freqüências da fertirrigação nitrogenada na produção de melão. Pesquisa Agropecuária Brasileira, v.29, n.9, p.1345-1350, 1994.

PINTO, J. M.; SOARES, J. M.; PEREIRA, J. R.; COSTA, N. D.; BRITO, L. T. de L.; FARIA, C. M. B. de; MACIEL, J. L. Sistema de cultivo de melão com aplicação de fertilizantes via água de irrigação. Brasília:Embrapa, SPI; Petrolina:Embrapa, CPATSA, 1996. 24p. (Embrapa-CPATSA. Circular Técnica, 36).

PIZARRO, F. C. Riegos localizados de alta frecuencia: goteo, microaspersion, exudacion. 2.ed. Madrid:Mundi Prensa, 1990. 471p.

POORTER, H. Inter specific variation in the growth response of plants to an elevated ambient $\mathrm{CO}_{2}$ concentration. Vegetatio, v. 104, p.77-97, 1993. 
PRABAHAKAR, B. S.; SRINIVAS, K.; SHUKLA, V. Yield and quality of muskmelon (cv. Hara madhu) in relation to spacing and fertilization. Progressive Horticuture, v.17, n.1, p.51-55, 1985.

PRADO, C. H. B. A.; MORAES, J. A. P. V.; MATTOS E. A. Gas exchange and leaf water status in potted plants of Copaifera langsdorffi. 1. Responses to water stress. Photosynthetica, v.30, n.2, p.207-213, 1994.

PUKHAL'SKAYA, N. V. Generative development of barley at an elevated atmospheric concentration of $\mathrm{CO}_{2}$ and varying temperature conditions. Russian Journal of Plant Physiology, v.44, n.2, p.177-182, 1997.

RAIJ, B. van . Fertilidade do solo e adubação. São Paulo:Agronômica Ceres, 1991. $136 \mathrm{p}$.

RICHARDS, L. A. Pressure-membrane apparatus - constructions and use. Agricultural Engineering, v.28, p.451-454, 1947.

RITSCHEL, P. S.; SOUZA, V. F. de; CONCEIÇÃO, M. A.; SOUZA, V. A. B. de; COELHO, E. F. Efeito da época de suspensão da irrigação na produtividade do meloeiro (Cucumis melo L.). In: CONGRESSO BRASLEIRO DE IRRIGAÇÃO E DRENAGEM, 10., Salvador, 1994. Anais. Salvador:Associação Brasileira de Irrigação e Drenagem, 1994. p.135-142.

ROCHA, A. M. dos S.; MORAES J. A. P. V. Influência do estresse hídrico sobre as trocas gasosas em plantas jovens envasadas de Stryphnodendron adstringens (Mart.) Coville. Revista Brasileira de Fisiologia Vegetal, v.9, n.1, p.43-48, 1997.

ROGER, G. S.; MILHAM, P. J.; THIBAUD, M. C.; CONROY, J. P. Interactions between rising $\mathrm{CO}_{2}$ concentration and nitrogen supply in cotton. I. Growth and leaf nitrogen concentration. Australian Journal of Plant Physiology, v. 23, n.2, p.119125, 1996. 
RUFTY Jr., T. W.; MACKOWN, C. T.; VOLK, R. M. Effects of altered carbohydrate availability on whole-plant assimilation of ${ }^{15} \mathrm{NO}_{3}$. Plant Physiology, v. 89, n.2, p.457$463,1989$.

RYALL, A. L.; LIPTON, W. J. Handling, transportation and storage of fruit and vegetables: vegetables and melons. Westport:AVI, 1972. v.1, 473p.

SAGE, R. F.; SHARKEY, T. D.; SEEMANN, J. R. Acclimation of photosynthesis to elevated $\mathrm{CO}_{2}$ in five $\mathrm{C}_{3}$ species. Plant Physiology, v.89, n.2, p.590-596, 1989.

SALISBURY, F. B.; ROSS, C. W. Plant physiology, 4.ed. Belmont:Wadsworth Publ., 1991. 682p.

SALOMÃO, L. C. C.; PINHEIRO, R. V. R.; CONDÉ, A. R.; SOUZÃO, A. C. G. de Efeito do desbaste manual de frutos em produtividade e na qualidade dos frutos de pessegueiros (Prumus persica (L.) Batsch), cultivar "Talismã". Revista Ceres, v.35, n.202, p.596-608, 1988.

SHANI, M. La fertilización combinada con el riego. Tel Avive: Ministerio de Agricultura, Sevicio de Extensión, 1981. 36p.

SHELLIE, K. C.; SALTVEIT Jr., M. E. The lack of a respiratory rise in muskmelon fruit ripening on the plant challenges the definition of climacteric behavior. Journal of Experimental Botany, v.44, n.265, p. 1403-1406, 1993.

SILVA, G. G. Armazenamento de melão, híbridos "Gold Mine" e "Duna" sob condições ambiente. Mossoró, 1992. 32p. Monografia (Graduação) - Escola Superior de Agricultura de Mossoró.

SILVA, J. da Cucurbitáceas: Influência de alguns fatores climáticos. Informe Agropecuário, v. 8, n. 85, p.20-21, 1982.

SMITH, D. H.; MOORE, F. D.; NOVERO, R.; SHANAHN, J. F.; D'ANDRIA, R. Fieldgrown tomato response to carbonated water application. Agronomy Journal, v.83, n. 5, p.911-916, 1991. 
SOUSSANA, J. F.; CASELLA, E.; LOISEUA, P. Long-term effects of $\mathrm{CO}_{2}$ enrichment and temperature increase on a temperate grass sward. II. Plant nitrogen budgets and root fraction. Plant and Soil, v. 187, n.1, p.101-114, 1996.

SOUZA, V. F. de Freqüência de aplicação de $\mathrm{N}$ e K via irrigação por gotejamento no meloeiro (Cucumis melo L. cv. Eldorado 300) em solo de textura arenosa. Botucatu, 1993. 131p. Dissertação (Mestrado) - Faculdade de Ciências Agronômicas, Universidade Estadual Paulista "Julio de Mesquita Filho".

SPAROVEK, G.; LEPSCH, I. F.; TORRADO, P. V.; MODOLO L. C.; PASSOS H. R.; VAZ., L. F. A.; BARBOSA, R. G. Avaliação das terras do campus "Luiz de Queiroz". Piracicaba: ESALQ, Depto. de Ciências do Solo, 1993. 28p.

STEWART, J. K. Decay of muskmelon stored in controlled atmospheres. Scientia Horticulturae, v.11, n. 1, p.69-74, 1979.

STUHLFAUTH, T.; FOCK, H. P. Effect of whole season $\mathrm{CO}_{2}$ enrichment on the cultivation of a medicinal plant, Digitalis lanata. Journal Agronomy \& Crop Science, v. 164, p.168-173, 1990.

TINKER, P. B. The role of microorganisms in mediating and facilitating the uptake of plant nutrients from the soil. Plant and Soil, v.76, n. 1/3, p.77-91, 1984.

TRAW, M. B.; LINDROTH, R. L.; BAZZAZ, F. A. Decline in gypsy moth (Lymantria dispar) performance in an elevated $\mathrm{CO}_{2}$ atmosphere depends upon host plant species. Oecologia, v. 108, n.1, p.113-120, 1996.

TYLER, K. B.; LORENZ, O. A. Nutrient absorption and growth of four muskmelon varieties. Journal of the American Society for Horticultural Science, v.84, n.1, p.191-195, 1964.

VESSEY, J. K.; HENRY, L. T.; RAPER Jr., C. D. Nitrogen nutrition and temporal effects of enhanced carbon dioxide on soybean growth. Crop Science, v.30, n.2, p.287-294, 1990. 
VIEIRA, A. T. Caracterização hidráulica de um tubo gotejador. Piracicaba, 1996. 56p. Dissertação (Mestrado) - Escola Superior de Agricultura "Luiz de Queiroz", Universidade de São Paulo.

VIEIRA, G. Índice de maturação para melão (Cucumis melo L.). In: SEMINÁRIO DE OLERICULTURA, 10., Viçosa, 1984. Anais. Viçosa:UFV, 1984. p.48-67.

VITOUSEK, P. M. Can planted forests counteract increasing atmospheric carbon dioxide? Journal of Environmental Quality, v.20, n.2, p.348-354, 1991.

WELLS, J. A.; NUGENT, P. E. Effect of high soil moisture on quality of muskmelon. HortScience, v. 15, n.3, p.258-259, 1980.

WONG, S. C. Elevated atmospheric partial pressure of $\mathrm{CO}_{2}$ and plant growth. I. Interactions of nutrition and photosynthetic capacity in $\mathrm{C}_{3}$ and $\mathrm{C}_{4}$ plants. Oecologia, v.44, n.1, p.68-74, 1979.

WONG, S. C. Elevated atmospheric partial pressure of $\mathrm{CO}_{2}$ and plant growth. II. Nonstructural carbohydrate content in cotton plants and its effect on growth parameters. Photosynthesis Research, v.23, n.2, p.171-180, 1990.

YAMAGUCHI, M.; HUGHES, D. L.; YABUMOTO, K.; JENNINGS, W. G. Quality of cantaloupe muskmelons: variability and attributes. Scientia Horticulturae, v.6, n.1, p.59-70, 1997. 